\title{
Final Performance Evaluation
}

\section{FinANCIAL ACCESS FOR INVESTING IN THE DEVELOPMENT OF AFGHANiSTAN}

This report was produced for review by the United States Agency for International Development (USAID). It was prepared under contract with Checchi and Company Consulting, Inc. for USAID's Afghanistan “Services under Program and Project Offices for Results Tracking Phase II” (SUPPORT II) project. 


\section{Activity Signature Page}

This report was contracted under USAID Contract Number: AID-306- C-12-00012. Afghanistan Services Under Program and Project Office for Results Tracking Phase II (SUPPORT II).

This Activity was initiated by the Office of Program and Project Development (OPPD) through Mr. Daryl Martyris, COR and Mr. Khalil Wardak ACOR for SUPPORT II.

Assignment Title: Final Performance Evaluation of the Financial Access for Investing in the Development of Afghanistan (FAIDA) program

Team Leader: Margaret Karuri

Team Members: Giovanni Recchi, Kamal Burhan, and Abdul Bari Siddiqi

Activity Start Date: April 23, 2015

Completion Date: June 8, 2015

\section{Michael Lechner, Chief of Party \\ Waheed Ahmadi, Deputy Chief of Party}

Checchi and Company Consulting, Inc.

Kabul, Afghanistan

\section{Disclaimer:}

The views expressed in this report are those of the author and do not necessarily reflect the views of USAID, the Government of the Islamic Republic of Afghanistan, or any other organization or person associated with this project. 


\section{TABLE OF CONTENTS}

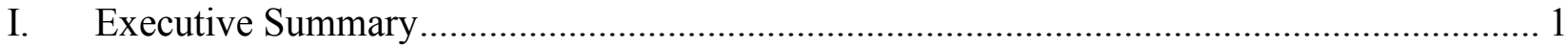

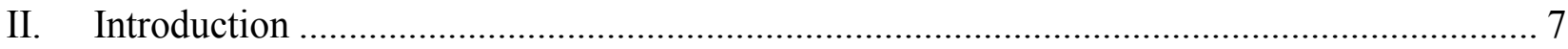

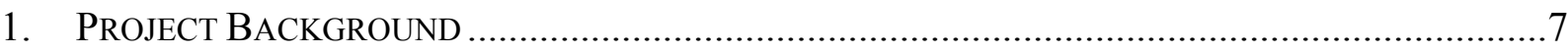

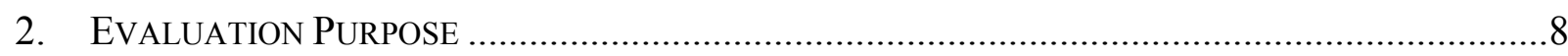

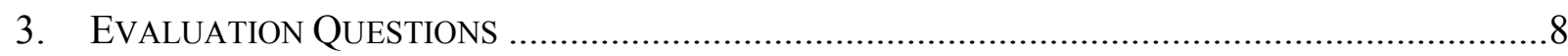

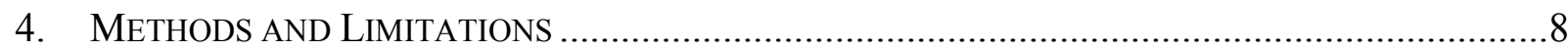

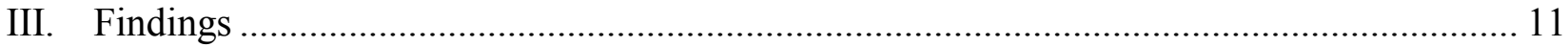

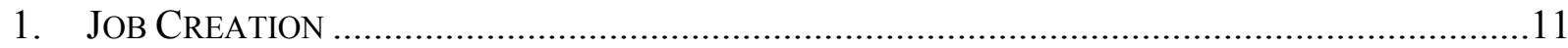

a. Number of Full-Time Equivalent Jobs Recorded ...................................................11

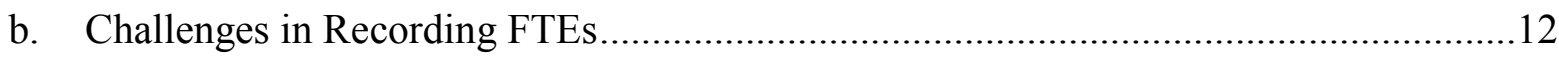

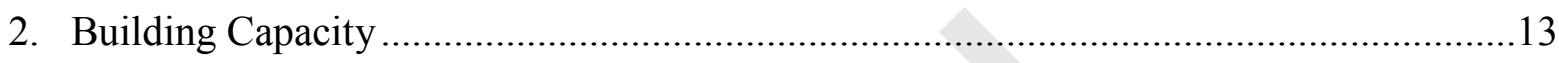

a. Enhancing the Capacity of Financial Professionals ...................................................13

b. Building Advocacy Skills of the Financial Sector Beneficiaries ...................................14

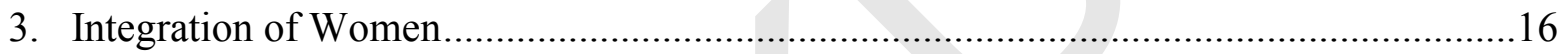

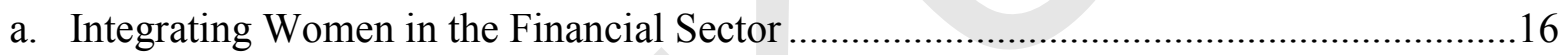

b. Constraints to Integrating Women in Business and the Financial Sector .....................17

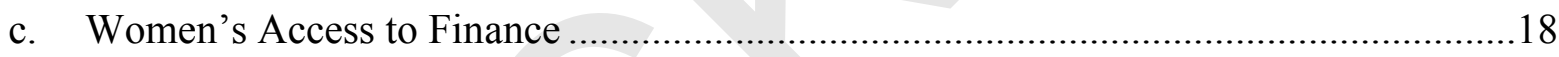

d. Women's Opportunities for Economic and Professional Growth.................................20

4. Mobile Network OPerators AND Mobile Money …....................................................21

a. Technical Assistance to Mobile Network Operators.....................................................21

b. MNOs' Performance in Introducing Innovative New Products and Services ................21

c. Challenges to Mobile Money Penetration ........................................................................23

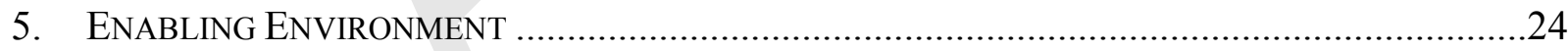

a. Effectiveness of Creating an Enabling Environment for Private Sector-Led Financial

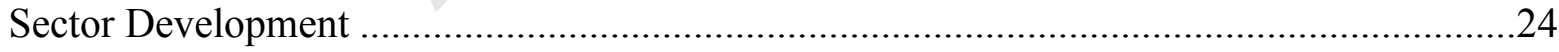

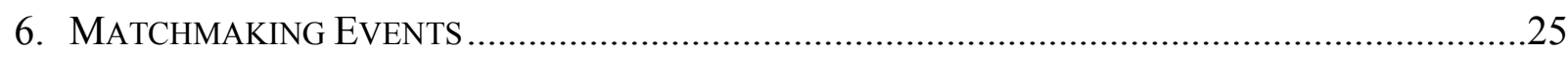

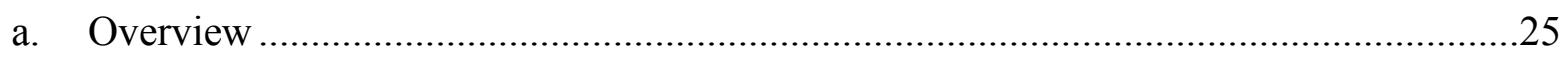

b. Effectiveness of Matchmaking Events in Facilitating Loans to MSMEs ......................26

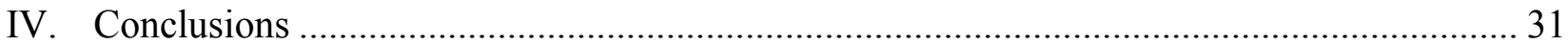

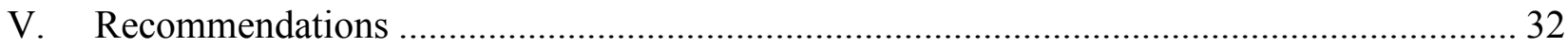

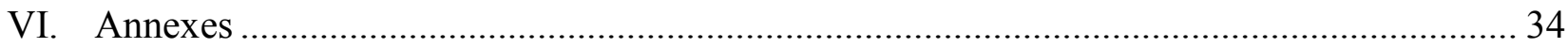

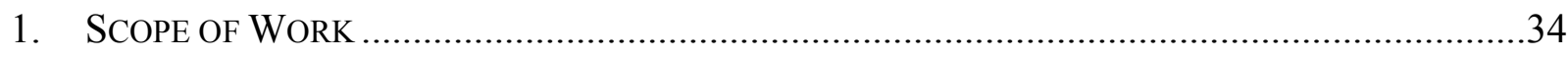

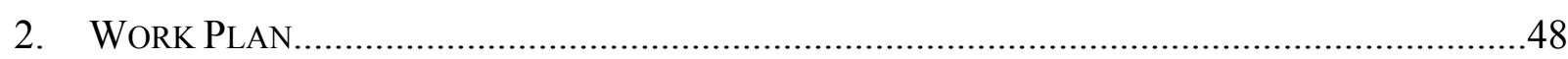

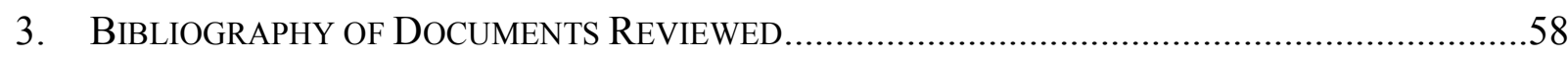

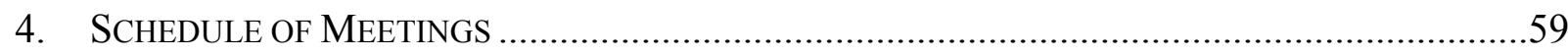




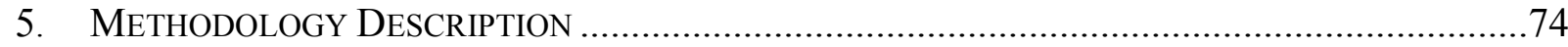

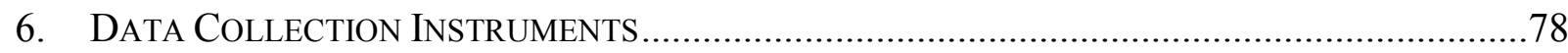

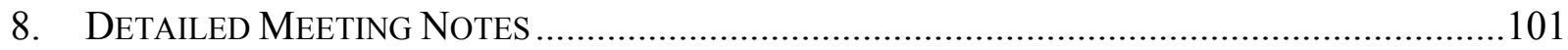

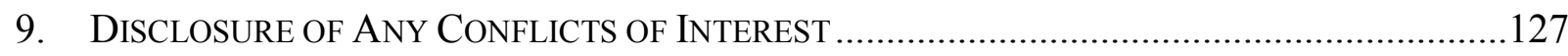

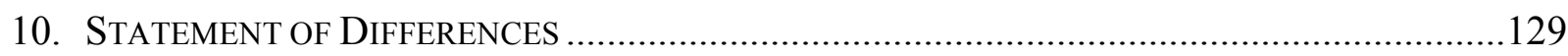

\section{LIST OF TABLES}

Table 1: Organizations and Numbers of People Interviewed ...............................................9

Table 2: Numbers of Beneficiaries Surveyed by Type of Activity and Province .................... 10

Table 3: Numbers of FTEs Created by Type of Organization and Gender ............................. 11

Table 4: Financial Sector Trainings Offered ……................................................................ 13

Table 5: Female Participation in Matchmaking Events, Trainings, and Workshops............... 17

Table 6: Private Financing Mobilized.................................................................................... 19

Table 7: Matchmaking FGD Loan Recipients by Type of Loan, Gender, and Region ...........20

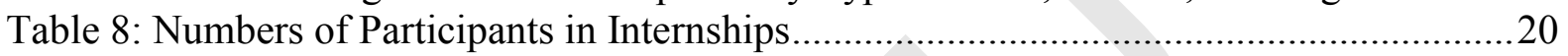

Table 9: Grants Awarded to Mobile Network Providers ........................................................ 21

Table 10: FAIDA-Supported Events/ Activities by Number of Participant and Gender ........26

Table 11: Benefits of Matchmaking Events by Number of Respondents and Gender ...........28

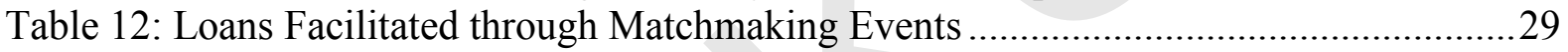

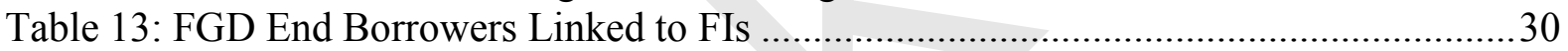

Table 14: FGD Borrowers by Loan Type, Region, and Gender............................................ 31 


\section{ACRONYMS}

ABA Afghanistan Banks Association

A2F Access to Finance

AIA Afghanistan Insurance Authority

ABA Afghanistan Banks Association

AIBF Afghanistan Institute of Banking and Finance

AIPA Afghanistan Insurance Personnel Association

AMA Afghanistan Microfinance Association

APS Afghanistan Payment System

AWBF Afghanistan Women Business Federation

AWCC Afghan Wireless Communication Company

B2B Business to Business

CN Concept Notes

DAB Da Afghanistan Bank (the Central Bank)

DFID Department for International Development

EMI Electronic Money Institution

FTE Full Time Employment

FGD Focus Group Discussions

FAIDA Financial Access for Investing in the Development of Afghanistan

FINCA Foundation for International Community Assistance

GIRoA Government of the Islamic Republic of Afghanistan

IIFC Islamic Investment and Finance Corporation

KCCI Kabul Chamber Of Commerce and Industries

M\&E Monitoring and Evaluation

MFIs Microfinance Institutions

MISFA Microfinance Investment Support Facility for Afghanistan

MNOs Mobile Network Operators

MoF Ministry of Finance

MSMEs Micro Small and Medium Enterprises

NGOs Non-Government Organizations

OEGI Office of Economic Growth and Infrastructure

SMEs Small and Medium Enterprise

SOW Statement of Work

STTA Short Term Technical Assistance

USA United States of America

USAID United States Agency for International Development

WB World Bank 


\section{EXECUTIVE SUMMARY}

\section{Project Background}

The USAID-funded Financial Access for Investing in the Development of Afghanistan (FAIDA) project aims to ensure large numbers of micro, small, and medium enterprises (MSMEs) have access to a diverse range of financial services. Implemented by Chemonics International with a budget of $\$ 108$ million, FAIDA began in 2011 and will end in 2016; this period includes an 18-month extension.

At the micro-level, FAIDA works with retail financial institutions to ensure that large numbers of clients, multiple segments of the population, and a broad geographic sector have improved access to credit. At the macro-level, FAIDA supports financial institutions' access to capital, bolsters technical support and educational services, and fosters advocacy capacity for the banking sector. Additionally, FAIDA is positioned to help the Government of Islamic Republic of Afghanistan (GIRoA) develop and implement favorable policies that would improve the financial sector enabling environment.

\section{Evaluation Questions, Design, Methods and Limitations}

This performance evaluation examines FAIDA's success in achieving its objectives from 2011 through 2014. In particular, it answers the following evaluation questions, which are based on FAIDA's three main components areas:

1. How effective and efficient have FAIDA's interventions been in creating jobs for men and women in MSME enterprises, financial institutions, and business associations?

2. How successful has FAIDA's assistance been in enhancing capacity of financial professionals and building advocacy skills for the financial sector beneficiaries, e.g., the Afghanistan Banks Association (ABA), the Afghanistan Microfinance Association (AMA), the Afghanistan Institute of Banking and Finance (AIBF), and the Afghanistan Insurance Personnel Association (AIPA).

3. To what extent have FAIDA's interventions integrated women in the financial sector and provided access to finance and opportunities for economic and professional growth?

4. How effective has FAIDA's technical assistance to Afghanistan's mobile network operators been in introducing innovative new products and services and expanding the use of mobile money?

5. What have been FAIDA's key achievements in improving the enabling environment for private-sector-led financial sector development, and how will they impact the sector in the long-run?

6. How successful were FAIDA's matchmaking events in linking financial institutions with MSMEs in need of financing (e.g., business roundtables, innovation fairs, conferences, workshops)? 
The Evaluation Team used a mix of quantitative and qualitative approaches to gather data in order to answer the above questions. The methodology included a desk review of important program documents, key informant interviews with stakeholders and beneficiaries, and focus group discussions (FGDs) with beneficiaries and participants in FAIDA-sponsored events.

The Evaluation Team conducted fieldwork in Kabul, Nangarhar, Balkh, Herat, and Kandahar provinces. In all, 31 senior-level finance and management officials were interviewed and five different types of FGDs with 159 participants (91 men and 68 women) were conducted.

The Evaluation Team was challenged by low turnout to the FGDs - on one occasion the turnout was zero. Other constraints included insecurity, which limited travel; illiteracy, which required the Evaluation Team to provide participants with additional help in filling out survey forms; and the time gap between when assistance was received and the time of this evaluation, resulting in some participants forgetting FAIDA's work.

\section{Findings ANd Conclusions}

\section{a. Job Creation}

According to FAIDA's data, the program created 5,396 full-time equivalent (FTE) jobs, $1,522(28 \%)$ of which are for women. This calculation is based on USAID's definition of FTE as eight-hours of work per day for 260 days out of the year. With FAIDA's assistance, financial institutions (FI) created the most FTEs $(4,664$, or $86 \%$ of the total). The other types of organizations supported by FAIDA - MSMEs, associations, NGOs, mobile network operators (MNOs) - only created between 19 and 349 jobs.

The micro-finance institute (MFI) Oxus Afghanistan is credited with creating 4,262 jobs (79\% of the total). FAIDA awarded Oxus Afghanistan a grant of $\$ 300,000$, which it used to leverage a loan of $\$ 3$ million from the Microfinance Investment Support Facility for Afghanistan (MISFA). Without Oxus, FAIDA's success in job creation was very limited totaling 1,134 direct FTEs over the course of four years. Attributing the 4,262 Oxus Afghanistan jobs created to FAIDA is in itself misleading. Oxus jobs were created by MSMEs and people who borrowed from the MFI, not by the MFI itself. The FTEs created by Oxus Afghanistan MSME's borrowers should be counted by FAIDA as indirect FTEs and not as direct FTEs.

Another problem in assessing job creation is that many organizations use different equations to calculate FTEs. For example, Oxus calculates FTEs by the size of the loan (e.g., 5,00049,999 Afs = 1 FTE), while the Agricultural Development Fund calculates FTEs by the type of employment (e.g., 1 full-time job = 1.2 FTEs). Last, not all of FAIDA's interventions were intended to produce jobs, and some beneficiaries absorbed the loans without expanding their human capacity. 


\section{b. Building Capacity}

As a result of FAIDA's assistance, 4,414 finance-sector employees received training to improve their job performance and skills. This number includes 1,142 mid-level (26\%) and 316 senior-level (7\%) staff, and 1,143 women (26\%). The Afghanistan Institute of Banking and Finance (AIBF) delivered trainings to the largest number of participants $(2,648)$, amounting to $60 \%$ of the total. Overall, the participants were satisfied with the course topics and content. AIBF placed three rounds of interns at FIs, but this activity received mixed reviews. Some FI officials felt there was a mismatch between the background of interns and their job duties at work.

In addition to grants for training, FAIDA provided direct financial and technical assistance to several financial sector organizations, including the Afghanistan Banks Association (ABA), the Afghanistan Microfinance Association (AMA), and the Afghanistan Intellectual Property Association (AIPA). The assistance helped these organizations develop and implement strategic plans, pay salaries, train staff, buy office furniture and equipment, attend industry meetings, and so forth. For example, discussions with ABA officials implied that the organization is far from achieving sustainability, as contributions from membership fees are insufficient to cover its overhead costs.

Much of FAIDA's assistance was demand-driven, based on the institutional assessment carried out and the expressed needs of the respective organizations. Nonetheless, most of the organizations remain unsustainable without donor support, and will continue to require technical assistance to perform core functions, including advocacy. A good example is that ABA received a grant of $\$ 500,000$. The evaluation was informed that the membership income generated from the 15 members does come close to sustaining ABA. The organization seems to have a credibility issue as some of its foreign branches members have not regularly paid their subscriptions.

\section{c. Integration of Women}

FAIDA included a gender mainstreaming component that was designed to better integrate women into the financial sector. Ten of its 16 indicators are disaggregated by gender. Women were invited to all of the FAIDA-supported matchmaking events, as well as women-specific business development trainings and workshops. Three hundred fifty-five women were also placed in internships at financial and government institutions. Many of the women who completed an internship received a job; a majority of that group (66\%) obtained a job at the same institutions where she interned.

As a result, FAIDA-supported FIs granted 1,410 of 5,158 loans (27\%) to female entrepreneurs. Loans to women totaled about $\$ 3$ million, $7 \%$ of the $\$ 44.45$ million in loans disbursed by FI's supported by FAIDA. Oxus Afghanistan accounted for $92 \%$ of the loans distributed to women. The fact that women received a minority of the loans - and for smaller amounts - is indicative of the constraints they encounter when attempting to access financing in Afghanistan, and the small number of women-owned businesses in existence. 
In the FGDs, which had 31 female participants, women expressed appreciation for FAIDA's assistance. One said it gave her confidence to work in a male-dominated environment, while another commented that she had been turned down for loans several times until FAIDA's intervention. Overall, FAIDA played a positive role in facilitating loans for businesswomen.

\section{d. Mobile Network Operators and Mobile Money}

FAIDA provided technical and finance assistance to mobile network operators (MNOs) to introduce new products and services and to expand the use of mobile money. The telecommunications companies Roshan, Etisalat, Afghan Wireless Communications Company, and MTN received grants of several hundred thousand dollars, in large part to implement mobile products identified in a "better-than-cash" university competition. These eight mobile products included applications to pay electricity fees and receive salaries.

To date, information received by the Evaluation Team from the MNOs seems to indicate that none of the mobile products have been developed. The impression is that the market for mobile money is very small, and thus unprofitable. A study by Altai Consulting in 2013 found that only $5 \%$ of the Afghan population uses mobile money. Altai attributed this to a lack of savings and therefore little need for financial services, low awareness of mobile money, and perceptions that mobile money is complicated and un-Islamic. In addition, Afghanistan lacks the required infrastructure and appropriate policies to guide the growth of mobile money.

\section{e. Enabling Environment}

FAIDA's policy interventions aimed to improve the enabling environment for private sectorled financial sector development. These were implemented under the regulatory component of the project and included technical and financial support to FIs, MNOs, and (as intended) to the Central Bank. However, an embargo prevented close cooperation with the Central Bank (DAB). The inability of FAIDA to engage with the Central Bank hampered its ability to influence new or modifications to existing policies.

FAIDA supported building the knowledge and management infrastructure of intermediary organizations as a way of enhancing their advocacy capacity to build an enabling environment. As the discussion for Subsection B showed, however, the institutions in question (ABA, AMA, AIBF, etc.) still face many challenges and are far from being sustainable.

The discussion for Subsection D reviewed the effect of FAIDA's technical assistance to Afghanistan's MNOs. An unwelcome environment, including the lack of policies, hampered the growth of mobile money.

\section{f. Matchmaking Events}

FAIDA held 95 matchmaking events, including innovation fairs, conferences, business roundtables, and workshops, to facilitate access to capital. These were attended by 11,384 
people, including 4,125 women (36\%) and people from all of the provinces and non-Afghans. The India-Afghanistan Innovation Partnership Fairs generated the largest number of participants, 5,463 in all, while the balance of 5,921 participants attended access to finance linking events. The effectiveness of the matchmaking events in linking FIs with MSMEs in need of loans can be assessed by the number of loans sought. While the India trade fairs were intended to facilitate trade, the other events were intended to link businesses to access to finance. A total of 1,308 Concept Notes were generated from these events. While widely attended, it seems most participants were not interested in applying for loans. This suggests that the matchmaking events were not very successful.

\section{RECOMMENDATIONS}

Job Creation (Evaluation Question 1)

1 Separate direct and indirect FTEs and report them as they are. In other FAIDA words, report MFI-MSME's generated FTEs as indirect and separate from FAIDA-support directly generated FTEs.

2 Standardize partner MFIs'/FIs' FTE calculations to make them comparable.

3 Reconsider the FAIDA-FTE reporting indicator, taking into account that the nature of some of the interventions being carried out do not necessarily result in additional jobs.

Advocacy and an Enabling Environment (Evaluation Questions 2 and 5)

1 Resolve the existing embargo on the Central Bank to open the way for USAID FAIDA and other US government projects to intervene effectively in supporting regulations that would create an enabling environment for a progressive and thriving financial sector

\section{Integration of Women (Evaluation Question 3)}

1 Endeavor to identify more businesswomen and assist them through the process of preparing their loan applications and documentation.

2 Future US government support should be geared towards finding solutions to the problems women face in accessing loans at reasonable rates, and in sufficient amounts to be able to grow their businesses

3 Negotiate with and encourage employers to accept more female interns as a way of empowering women to seek employment.

4 To improve incomes and ability of women to repay loans, consider studying how women can be assisted to establish marketing cooperatives as

FAIDA outlets for marketing of their goods.

USAID

5 On issue of internships, improve the candidate selection process for the FAIDA internship program and make AIBF trainings relevant to the sectors to which the interns are posted. 
Mobile Network Operators (Evaluation Question 4)

1 Allow MNOs to lead the expansion of Mobile Money services based on their best business practices.

2 Consider implementing the recommendations made by Altai Consulting FAIDA study to boost penetration and usage of Mobile Money services in Afghanistan.

\section{Matchmaking Events (Evaluation Question 6)}

1 Broaden the range of participants invited to matchmaking events and avoid $\quad$ FAIDA recycling same people in these functions/events.

2 Conduct an assessment of Islamic loan products across the financial sector

FAIDA to determine what exists, the form it is in, where gaps exists, and incorporate the Central Bank in the development of these products.

3 Review the computation for the amount of private finance mobilized

FAIDA through loans generated by Oxus Afghanistan. These are not directly linked to FAIDA's efforts.

4 Monitor concept notes, business plans, and conduct exit surveys on the

FAIDA matchmaking events as a way of gauging the effectiveness of the approach in facilitating loans to MSMEs, and change approach if need be. 


\section{INTRODUCTION}

\section{Project Background}

USAID's Financial Access for Investing in the Development of Afghanistan project (FAIDA) promotes financial inclusion across Afghanistan through initiatives designed to support a sustainable, commercially-viable, local, and national economy as the best way to achieve long-term stability, security, and enduring peace. The overall objective of FAIDA is job creation through a sustainable, diverse, and inclusive financial sector that can meet the needs of micro-small and medium-sized enterprises (MSMEs) throughout Afghanistan.

Implemented by Chemonics International with a budget of $\$ 108$ million, FAIDA began in February 2011 and will conclude in February 2016, which includes an 18-month extension.

The project contributes to USAID objectives under: Intermediate Result (IR) 1: Enhanced outreach of retail financial institutions at the micro level (retail financial institutions); IR 2: Enhanced capacity of financial system support services and infrastructure at the meso-level (financial market infrastructure); IR 3: Improved enabling environment for private sector-led financial sector development at the macro-level (policy environment); and IR 4: Expanded financial inclusion using a combination of technical assistance, grants, and public-private partnerships to promote system functionality, awareness, and uptake of all forms of electronic payments, branchless banking, and mobile money.

FAIDA was implemented under the following major components:

- Enterprises: Works with partner institutions to provide tailored financial solutions where access to capital will complete value chains and increase competitiveness. Links lenders to businesses in need of financing, with a special focus on remote areas.

- Banking Capacity: Enhances the capacity of financial professionals and organizations to strengthen Afghanistan's financial sector. Supports the introduction of Islamic and conventional financial services and products to lenders and the private sector.

- Regulation: Creates an enabling lending environment that reduces risk and increases certainty. Develops new or updated regulations across all financial sectors and key institutions.

- Better-Than-Cash: Provides technical assistance to Afghanistan's mobile network operators to introduce innovative new products and services and expand the use of mobile money.

- Gender Mainstreaming: Ensures that women are integrated in financial sector activities and are provided access to finance and opportunities for economic and professional growth. 


\section{Evaluation Purpose}

This evaluation covered FAIDA's performance from 2011 through 2014. Specifically, the evaluation considered the quality and effectiveness of FAIDA's interventions in the following areas:

a. MSME jobs created as a result of FAIDA's activities;

b. FAIDA's technical assistance and grants for sub-award recipients to build their institutional and human capacity and advocacy skills. These sub-awardees are: the Afghanistan Banks Association (ABA), the Afghanistan Microfinance Association (AMA), the Afghanistan Institute of Banking and Finance (AIBF), and the Afghanistan Insurance Personnel Association (AIPA);

c. Loans facilitated with support of US government assistance through FAIDA, including for female borrowers and underserved MSMEs; and

d. Regulatory component, including policy, legal, and regulatory frameworks, to determine the extent to which the objectives for this component were achieved.

\section{Evaluation Questions}

The evaluation is guided by the following six evaluation questions:

1. How effective and efficient have FAIDA's interventions been in creating jobs for men and women in MSME enterprises, financial institutions, and business associations?

2. How successful has FAIDA's assistance been in enhancing the capacity of financial professionals and building advocacy skills for the financial sector beneficiaries (e.g., ABA, AMA, AIBF, and AIPA)?

3. To what extent have FAIDA's interventions integrated women in the financial sector and provided access to finance and opportunities for economic and professional growth?

4. How effective has FAIDA's technical assistance to Afghanistan's mobile network operators been in introducing innovative new products and services and expanding the use of mobile money?

5. What have been FAIDA's key achievements in improving the enabling environment for private-sector-led financial sector development, and how will they impact the sector in the long-run?

6. How successful were FAIDA's matchmaking events in linking financial institutions with MSMEs in need of financing (e.g., business roundtables, innovation fairs, conferences, workshops)?

\section{Methods ANd Limitations}

The FAIDA evaluation covered five geographic locations: Kabul, Kandahar, Herat, Balkh, and Nangarhar. In each region, the team met with both men- and women-owned MSMEs in order to determine whether the program has been successful in improving access to a diverse 
range of financial services. FAIDA's activities were not necessarily homogenous across all five geographic locations, and differing approaches were therefore required to evaluate its performance, especially at the enterprise, banking capacity, and mobile network operators' levels. A detailed description of the methodology is provided in Annex V of the report.

Desk Review - The Evaluation Team reviewed a variety of program operational documents and reports provided by USAID, including: performance monitoring and evaluation (M\&E) reports, impact assessments and previous evaluation reports, implementation work plans, quarterly and annual implementation progress reports, and other internal M\&E documents from the FAIDA program.

Key Informant Interviews - The Evaluation Team held face-to-face interviews with some of the key stakeholders involved directly and indirectly with the FAIDA program, including: FAIDA's project staff and managers in Kabul and field offices; managers and Chief Executive Officers of key financial intermediaries, such as Oxus Afghanistan and the Islamic Investment Finance Corporation (IIFC); financial sector umbrella/supervisory bodies, including the Central Bank, ABA, AIBF, and AMA; and mobile network operators (MNOs).

Table 1 lists the organizations consulted and the number of persons met at each. The full list of organizations and persons met by the Evaluation Team is provided in Annex IV of the report. In total, the Evaluation Team met with 31 senior-level officials, including several CEOs.

Table 1: Organizations and Numbers of People Interviewed

\begin{tabular}{|l|c|l|c|}
\hline Organization & $\begin{array}{c}\text { Number of } \\
\text { Persons Met }\end{array}$ & Organization & $\begin{array}{c}\text { Number of } \\
\text { Persons Met }\end{array}$ \\
\hline ABA & 2 & FINCA & 1 \\
\hline AIBF & 1 & IFC & 1 \\
\hline AIPA & 1 & IIFC & 1 \\
\hline AMA & 1 & KCCI & 1 \\
\hline APS & 2 & MISFA & 1 \\
\hline AWCC & 1 & Oxus & 2 \\
\hline Etisalat & 2 & Oxus Afghanistan & 2 \\
\hline FAIDA & 11 & Roshan & 1 \\
\hline Grand Total 31 & & \multicolumn{2}{|l}{} \\
\hline
\end{tabular}

Source: FAIDA Evaluation Tools

Focus Groups Discussions (FGDs) - The Evaluation Team developed tools for data collection, which included:

- MSME end-borrowers FGD questionnaires

- FAIDA matchmaking questionnaires 
- Gender mainstreaming questionnaires

- Mobile money end-user questionnaire

- Banking capacity component interview guides

Initially, the Evaluation Team intended to invite 300 beneficiaries to participate in the focus groups discussions. In all, in the five evaluation program provinces of Kabul, Balkh, Herat, Kandahar, and Nangarhar, the team interviewed 159 FAIDA beneficiaries (91 men and 68 women) in mobile money, matchmaking, women's access to finance, and end-borrowers FGDs. Table 2 gives a breakdown of the surveyed beneficiaries by type of activity and province. Samples of the data collection instruments used to conduct the survey are included in Annex VI.

Table 2: Numbers of Beneficiaries Surveyed by Type of Activity and Province

\begin{tabular}{|l|c|c|c|c|c|c|}
\hline Type & Balkh & Herat & Kabul & Kandahar & Nangarhar & Totals \\
\hline End Borrowers & 9 & 14 & 8 & 15 & 13 & 59 \\
\hline Gender & 8 & 12 & 8 & 3 & 7 & 38 \\
\hline Matchmaking & 11 & 16 & 6 & 9 & 2 & 44 \\
\hline Mobile Money & 3 & & 6 & 7 & 2 & 18 \\
\hline Totals & $\mathbf{3 1}$ & $\mathbf{4 2}$ & $\mathbf{2 8}$ & $\mathbf{3 4}$ & $\mathbf{2 4}$ & $\mathbf{1 5 9}$ \\
\hline
\end{tabular}

Source: FAIDA Evaluation Tools

Modification in the Methodology - The initial approach was for the Evaluation Team to select 50 interviewees per province based on the list provided by FAIDA. The approach did not generate the numbers required. The Evaluation Team decided to change the approach in Herat and to asked FAIDA to invite more people

Data Analysis - The evaluation tools were designed in line with the six evaluation questions in the SOW. Once fieldwork was completed, the data was checked, cleaned, and entered into a database. Quantitative data collected was analyzed using established evaluation techniques and standard data analysis tools. These tools enabled evaluators to evaluate not only descriptive statistics (such as the number of people surveyed, the percentage of women, and the number of respondents reporting a given problem or benefit), but also perform more advanced analytical exercises such as measures of correlation between various variables. The data is stored both soft and hard copies.

\section{Evaluation Constraints}

The main challenge faced by the Evaluation Team was the low turnout for the FGDs; on occasion it was zero. Administering questionnaires also proved a challenge as some participants could not read and/or write, forcing the Evaluation Team to assist them in completing the questionnaires, which took longer than anticipated. Security is always a concern in the districts, where most of the beneficiaries are located, making it difficult for them, especially for women, to travel. Since a number of questions during the interviews 
dealt with issues that took place in the past, some people invited did not know or remember FAIDA. Some respondents had difficulties recalling accurately the role played by FAIDA.

\section{FINDINGS}

\section{Job CREATion}

\section{a. Number of Full-Time Equivalent Jobs Recorded}

USAID defines a full-time equivalent (FTE) job as 260 working days in a year. FAIDA asked recipients of its technical support or assistance to report jobs created over the life of the project, in order to capture the number jobs attributable to the program. To calculate full-time equivalent jobs, FAIDA adds the eight-hour days worked by permanent, part-time, and seasonal employees and divides it by 260 .

FAIDA's interventions have created 5,396 FTEs, of which 3,874 (72\%) are for men and $1,522(28 \%)$ for women. The FTEs were created either from use of program funds or from counterpart contribution in support of the activity/initiative funded, with US government funds ascribed to FAIDA's program results. Table 3 gives the number of FTEs created by type of organization and gender.

Table 3: Numbers of FTEs Created by Type of Organization and Gender

\begin{tabular}{|l|c|c|c|}
\hline Type of Organization & Male & Female & Total \\
\hline Associations & 77 & 13 & 90 \\
\hline Financial Institutions & 3,369 & 1,294 & 4,664 \\
\hline Mobile Network Operators & 58 & 1 & 60 \\
\hline Micro-Small and Medium Enterprises & 349 & 190 & 539 \\
\hline Non-Governmental Organizations & 19 & 24 & 43 \\
\hline Grand Total & $\mathbf{3 , 8 7 2}$ & $\mathbf{1 , 5 2 2}$ & $\mathbf{5 , 3 9 6}$ \\
\hline
\end{tabular}

Source: FAIDA Secondary Data

Associations: FAIDA created 90 jobs at business associations, which include FTEs for 77 men and 13 women. This is the result of FAIDA's interventions in support of financial services institutions at the macro level of the financial system, agriculture activities, and in all of FAIDA's activities.

Financial Institutions: A total of 4,664 FTEs were attributed to financial institutions $(3,369$ for men and 1,294 for women). Seventy-nine percent of the FTEs are attributable to a single micro-finance institution, Oxus Afghanistan. These are FTEs generated by the MFI's MSME borrowers, not from FAIDA's direct support to Oxus Afghanistan. Oxus determines the number of FTEs by the size of loans generated: 5,000-49,999 Afs = 1 FTE; 50,000-199,999 Afs $=2$ FTEs; and 200,000 + Afs $=3$ FTEs. It should be noted that not all microfinance loans 
generate jobs. Many MSMEs borrow to utilize existing capacity and not necessarily to create more jobs.

Overall, there seems to be confusion on how to calculate FTEs, with each organization appearing to apply its own methodology. The Foundation for International Community Assistance (FINCA) does not have any system to record FTEs for the number of existing employees or after the loans. The Islamic Investment and Finance Corporation (IIFC) uses the Microfinance Investment Support Facility for Afghanistan (MISFA) model of multiplying loans in the range of 25,000 to 500,000 Afs by 1.5 FTEs. The Agricultural Development Fund (ADF), another USAID project, reports FTEs based on a formula given by USAID in the project implementation plan: 1 full-time job $=1.2$ FTEs; 1 part-time job $=0.6$ FTEs; and 1 seasonal job $=0.11$ FTEs. Unless there is a way of harmonizing the way FTEs are calculated across US government-funded projects, then obtaining consistent data remains a challenge.

Micro-Small and Medium Enterprises: A total of 539 FTEs jobs (349 for men and 190 for women) were attributed to partner MSMEs receiving FAIDA support through direct beneficiaries, such as the financial institutions.

Mobile Money Activities: FAIDA's mobile money activities created 60 FTEs, consisting of 59 jobs for men and one for a woman. Only part-time jobs were counted under this indicator. Some of these jobs were created through FAIDA's direct intervention in recruiting mobile money agents. The MNOs did not use most of the mobile money agents trained by FAIDA, as they already had enough agents.

Non-Governmental Organizations: NGOs received grants from FAIDA to build their capacity, creating 43 FTEs ( 9 for men and 24 for women).

\section{b. Challenges in Recording FTEs}

As noted above, the bulk of the FTEs created were at a single MFI (Oxus Afghanistan), where FAIDA recorded 4,262 jobs. These are jobs generated indirectly by MFI borrowers, not by Oxus itself. Recording these FTEs as a direct result of FAIDA support to the MFI is misleading. They should be recorded as indirect FTEs. Without the count of these jobs, FAIDA's interventions cannot be said to have been effective and efficient in creating jobs, as only 1,134 jobs would have been created.

On the other hand, not all of FAIDA's interventions generate additional employment. In most cases, the recipient institution can implement FAIDA's support by using its existing human capacity. Reporting on the FTE indicator requirement by USAID for FAIDA may have to be reconsidered, taking into consideration that the nature of some of the interventions being carried out do not necessarily result in additional jobs. 


\section{Building Capacity}

\section{a. Enhancing the Capacity of Financial Professionals}

FAIDA data reviewed by the Evaluation Team shows that a total of 4,414 financial-sector staff were trained under FAIDA support. Of the 1,142 professionals trained, 771 (682 men and 89 women) are middle-level staff; and 316 (263 men and 53 women) are senior staff. Fifty-five other staff ( 37 men and 18 women) were not classified. Only 160 of those trained were women $(14 \%)$, an indication of the low numbers of professional women employed in the sector. There are more women in the general category of employees trained, numbering 1,282 of the total trainees (39\%). Table 4 gives a breakdown of the number of staff trained by category, gender, and training provider.

Table 4: Financial Sector Trainings Offered

\begin{tabular}{|c|c|c|c|c|c|c|c|}
\hline & \multicolumn{3}{|c|}{$\begin{array}{c}\text { 2.3 Financial Professional } \\
\text { Trained }\end{array}$} & \multicolumn{3}{|c|}{$\begin{array}{c}\text { 2.2 Financial Sector Employees } \\
\text { Trained }\end{array}$} & \multirow[b]{2}{*}{$\begin{array}{l}\text { Grand } \\
\text { Total }\end{array}$} \\
\hline Training Provider & Male & Female & Total & Male & Female & Total & \\
\hline AIBF & 654 & 75 & 729 & 1,239 & 716 & 1955 & 2,684 \\
\hline AMA & 104 & 43 & 147 & 233 & 181 & 414 & 561 \\
\hline Banking Capacity & 79 & 25 & 104 & 208 & 186 & 394 & 498 \\
\hline Enterprise & 145 & 13 & 158 & 303 & 105 & 408 & 566 \\
\hline Gender & 0 & 4 & 4 & - & 87 & 87 & 91 \\
\hline Roshan & - & - & 0 & 7 & 7 & 14 & 14 \\
\hline Grand Total & 982 & 160 & 1,142 & 1,990 & 1,282 & 3,272 & 4,414 \\
\hline$\%$ & 86 & 14 & 100 & 61 & 39 & 100 & \\
\hline
\end{tabular}

Source: FAIDA Secondary Data

In terms of training providers, the Afghanistan Institute of Banking and Finance (AIBF) trained the majority participants, 2,684 in all. Owned by the Central Bank, ABA, and MISFA, AIBF is dedicated to strengthening the human capacity of Afghanistan's financial sector and establishing a center of excellence for banking and finance. The Evaluation Team met with AIBF, AMA, and Roshan, among the training providers listed. At the time of the evaluation, AIBF was experiencing some internal management wrangles that constrained its ability to deliver effective training to the sector. Consequently, some donors like FAIDA chose to withhold support until these issues had been resolved. Some of the MFIs interviewed felt that AIBF's quality of training has declined substantially over time, and they were not fully delivering on their mandate. This has prompted organizations such as AMA to embark on their own staff training; and at the time of the evaluation it was being proposed that AMA and AIBF conduct joint training, a proposal that AIBF was strongly opposed to. At the time of the evaluation, according to AIBF, the partnership agreement with AMA was yet to be signed.

A review of FAIDA data shows that AIBF was offering a diverse range of training courses very relevant to building different levels of the human capacity in the financial sector. The Evaluation Team inspected some of student course assessment questionnaires and noted that, overall, the participants were satisfied with the course content, training materials, and 
instructors hired by AIBF. Some of the challenges faced by AIBF, as told to the Evaluation Team, include a limited training budget for trainers $(\$ 2,200)$. AIBF is unable to hire experienced banking staff to conduct the trainings with the available budget. AIBF's commitment to become self-sustaining in five years is also not attainable, as it is only able to generate income equal to $5 \%$ of its total expenses.

On the issue of women in finance internships, the Team learned that AIBF and FAIDA had placed three rounds of interns. Some MFIs interviewed were not happy with quality of intern trainings, as they did not find a good match between the interns' major fields of study and banking. Hence, there is a need to improve the candidate selection process for the internship program and make AIBF trainings relevant to the sectors to which the interns are posted. In addition to AIBF trainings, the MFIs interviewed requested external training for their senior managers, as well as exchange programs for exposure to world-class MFIs' best practices.

\section{b. Building Advocacy Skills of the Financial Sector Beneficiaries}

The Evaluation Team met with some of FAIDA's financial sector beneficiaries, including the MISFA, AMA, ABA, AIBF, and AIPA to determine how FAIDA has engaged with them in building their advocacy skills. By building the knowledge management infrastructure of these intermediary institutions, FAIDA's goal was to enhance their advocacy skills in creating an enabling environment that would accelerate the development and expansion of a financial sector led by the private sector in Afghanistan.

Afghanistan Microfinance Association: The AMA was created by the splitting of MISFA's functions, to coordinate MFIs and advocacy. MISFA is owned by the Ministry of Finance of Afghanistan and registered as a limited liability company with AISA. It was established as a vehicle through which the Afghan Government and international donors could pool diverse donor funding mechanisms, and convert it into flexible support to microfinance institutions in Afghanistan. MISFA is the only second-tier lender to MFIs in Afghanistan. MISFA has adequate funding, with FAIDA providing minimal support, including some grants for developing the association's strategic plan and hiring a technical assistance advisor.

FAIDA's support to AMA included an organizational assessment; financial and technical support; office refurbishment with office equipment; support with salaries; a training assessment for the financial sector in 2012; and a salary survey for the sector, which it found to be very helpful. The second grant was used for membership expansion, regional coordination and networking, and trainings to MFI staff in regions outside Kabul. With capacity built by FAIDA, AMA was able to transition some regional offices, MFIs' advocacy, and communications and lobbying from MISFA. AMA was also able to conduct some trainings to fill gaps not covered by AIBF, such as Islamic finance, and to take over from FAIDA the women-in-finance trainings, of which they conducted ten. Although FAIDA's support helped to build the AMA's credibility, the organization complained that FAIDA takes too long to respond to requests. AMA faces challenges of sustainability as it is 
only able to raise only $10 \%$ of its operational expenses through fees. AMA has 14 MFI members and receives $90 \%$ of its support from MISFA.

Afghanistan Institute of Banking and Finance: The AIBF received a seed grant from FAIDA to expand AIBF's training capacity through a distance-learning program, and to set up microfinance and Islamic finance departments. During meetings with AIBF, the Evaluation Team was informed that they are only able to generate revenues to cover just $5 \%$ of its expenses. AIBF is financially supported by FAIDA, the World Bank, and other donors. FAIDA, on the other hand, contends that AIBF has covered $19.87 \%$ of its average cost via training fee revenues during the year 2014, and 20.8\% during the first two quarters of 2015 . Whatever the case, there remains a shortfall, and AIBF is in dire need of financial support to effectively implement its training mandate.

Afghanistan Banks Association: Established in 2004, ABA is an independent organization with 15 member banks. In view of the US government's embargo on working with the Central Bank, FAIDA has worked closely with ABA to strengthen its legitimacy and lobbying and advocacy functions. FAIDA's grant of $\$ 500,000$ helped implement a strategic plan, which included determining ABA's structure, developing promotional material, and providing the anti-money laundering (AML) training to the Central Bank. The ABA faces serious issues of sustainability, as the Evaluation Team was informed foreign bank branches and some local banks are not committed, and do not regularly pay their membership fees.

In addition, the Team learned of some outstanding issues over which ABA will require future support, including: developing a terms of reference for the expat legal advisor, translating $\mathrm{DAB}$ regulations that are written in English, and rectifying misperceptions about Islamic banking through an awareness campaign. Short-term technical assistance (STTA) is needed at $\mathrm{ABA}$ and $\mathrm{DAB}$ to deal with property appraisal issues in order to develop a mortgage market. There is also a need to increase members' confidence in ABA's ability to represent them, help it establish contacts and exposure to regional banking associations, and work towards being sustainable.

Despite efforts to strengthen ABA's advocacy functions, the Evaluation Team is of the view that not much can be achieved without the active participation of the Central Bank as the custodian and regulator of the financial sector. Lack of engagement with DAB has limited FAIDA's ability to influence and support the creation of an enabling environment. Hence, there is need for both the Central Bank and the US government to deal with the deadlock for FAIDA and other US government interventions to be effective in supporting an enabling environment for a thriving financial sector.

Afghanistan Insurance Personnel Association: The AIPA was established to give Afghan insurance companies a voice. FAIDA supported AIPA in implementing the first-year activities of its three-year strategic plan, including: providing access to finance and insurance industry meetings; paying for accommodations and fees at Dubai insurance industry meetings; paying licensing fees (40,000 AFs) for AIPA; providing generator and office 
furniture; and writing letters to regulators. The organization complained that FAIDA takes too long to make decision.

Afghanistan needs to consider compulsory insurance for issues like traffic accidents and fires. AIPA says banks do not understand that compulsory insurance for loans/collateral is way of managing risk. The industry also faces constraints in finding insurance professionals. Since 1964, there has been a significant attrition in Afghan insurance professionals. AIPA has requested support from FAIDA in establishing a pilot program for provincial offices, but it has not been received. Another challenge is that insurance policies are written in English and are difficult to understand. In meetings with AIPA officials, some of the needs expressed included: budget and technical support, assistance in developing standardized policies and improving claims processes, and assistance in developing awareness among the general public of the benefits of insurance, among others.

Overall, in building advocacy skills, FAIDA's support has been ad hoc and demand-driven, based on the expressed needs of respective financial sector players. Because FAIDA's interventions have been more reactive than proactive, it is difficult to credit the program with any specific interventions. The ad hoc approach was intended to enable FAIDA to work with a broad range of retail financial institutions and delivery models and accommodate diverse goals within Afghanistan's financial sector. The approach, however, makes it difficult for the evaluators to determine the extent to which projects goals have been met. A large number of clients were engaged by FAIDA within a broad geographic area, but this did not necessarily translate to more MSMEs accessing finance or making business connections.

As far as the policy environment is concerned, engaging with the Central Bank is a key ingredient to achieving much under the regulatory component. The ban on working with DAB hampered FAIDA's interventions in creating an enabling lending environment that reduces risk and increases certainty, and in assisting with the development of new or updated regulations across the financial sector and its key institutions.

\section{Integration of Women}

\section{a. Integrating Women in the Financial Sector}

Gender mainstreaming is a cross-cutting issue and involves all technical components of FAIDA. FAIDA was designed to integrate Afghan female entrepreneurs in financial sector activities through targeted business development training that would enable them to gain access to financing and opportunities for economic and professional growth. The project has 16 indicators, of which ten are disaggregated by gender. To increase women's access to finance and further their economic and social empowerment, women were invited to all 95 of FAIDA's matchmaking events, and to women-specific business development opportunities workshops and trainings. In total, 4,125 women (36\% of the total participants) attended these events. 
More women attended the women-specific activities, numbers 4, 5 and 6, as shown in Table 5 , than trainings open to both sexes. This is because cultural and religious constraints do not permit women to freely attend public forums. Hence, any intervention targeting women should be sensitive to such cultural and religious issues.

Table 5: Female Participation in Matchmaking Events, Trainings, and Workshops

\begin{tabular}{|c|l|c|c|c|c|}
\hline & $\begin{array}{c}\text { Total } \\
\text { Events }\end{array}$ & Male & Female & $\begin{array}{c}\text { Total } \\
\text { Participants }\end{array}$ \\
\hline 1 & B2B & 41 & 2259 & 889 & 3148 \\
\hline 3 & Innovation & 3 & 4402 & 1061 & 5463 \\
4 & Contract Farming Workshops & 9 & 287 & 156 & 443 \\
\hline 5 & AMA-Women's Access to Islamic Financing & 28 & 264 & 1562 & 1826 \\
& Finance Workshop & & & & \\
6 & Business Planning Training for Businesswomen & 9 & 46 & 253 & 254 \\
\hline & Total & $\mathbf{9 5}$ & $\mathbf{7 , 2 5 9}$ & $\mathbf{4 , 1 2 5}$ & $\mathbf{1 1 , 3 8 4}$ \\
\hline
\end{tabular}

Source: FAIDA Secondary Data

The Evaluation Team held three types of FGDs in which women were represented. These were focus groups for gender, matchmaking, and end borrowers. Thirty-one women attended the gender FGD to review FAIDA's work in integrating women in the financial sector. Eight women had received conventional loans and five Sharia-type loans.

Of the 45 participants that attended the matchmaking FGD, 20 were women. A female participant in the FGD held in Kabul commended FAIDA's workshops for women, as they helped to build women's self-esteem and courage to work in a male-dominated environment in Afghanistan. In Herat, women who participated in the end-borrowers FGD felt that financial institutions discriminated against them by the volume of documentation required to support their applications, including signatures of guarantors. One businesswoman said she had failed in several attempts to secure a loan until FAIDA introduced her to an MFI. Some women were able to access larger loans than before with FAIDA's support. Women also reported that MFIs demanded less documentation and security when their applications were processed through FAIDA. To a large extent, FAIDA seems to have played a positive role in facilitating loans to women.

\section{b. Constraints to Integrating Women in Business and the Financial Sector}

One female participant in the gender FGD in Kabul summed up the challenges that women face in Afghanistan: "It is very hard for women to work in this country. Men have all the benefits." Financial constraints are attributed to a variety of factors, including: a lack of collateral with which to secure loans, forcing women to seek support from male family members to guarantee their loans; lack of financial literacy, hence many are unable to complete the loan application materials; a lack of confidence and risk-averseness; and 
discomfort in working with male loan officers, particularly in a gender-divided society such as Afghanistan. Although not unique to women, some potential borrowers cannot determine the level of credit suitable for their businesses, where and how to access credit, and how to prepare the required documentation and analysis to qualify for the credit.

Women also lack the long-term business track records and formal credit histories required by most financial institutions. Because of these constraints, women either do not borrow or depend on reinvesting their profits, or when they borrow they depend on male family members to secure the loans for them. Because of these constraints, women normally take small loans from MFIs, which do not require tangible collateral, further constraining the growth of their businesses. For women who worked with FAIDA, the project provided them with the required support to prepare their loan applications. With improved documentation and information, FIs were more willing to approve loans for women. Continued support should be geared at finding a mechanism by which more women can receive support to prepare their loan proposals.

In the FGDs, women lamented the challenges they also encounter in marketing their products. Most of the women tend to work from their homes, weaving carpets and producing other items that they are unable to sell. They depend on buyers, mostly men, who offer them low prices. Businesswomen also have cultural constraints in traveling out of the country to participate in exhibitions and trade fares, due to the requirement that they be accompanied by a mahram (male guardian). Hence, future interventions should consider how they can pool women together into cooperatives, through which they can market their produce. Cooperatives give women access to new customers, are easier to join, and are cheaper than striking out on their own. Exhibitions for women's products open to everyone in the regions would also be a good way of getting women to introduce their products. Women in FGDs also requested more training and support in introducing variety and new designs in their businesses. Some women requested specialists in carpet weaving who can help them introduce new designs.

\section{c. Women's Access to Finance}

FAIDA facilitated 5,138 borrowers in obtaining loans from 12 financial institutions. Only 1,410 of the borrowers, equivalent $27 \%$ of total borrowers, are women. These women received loans amounting to $\$ 3,012,623$, equivalent to $7 \%$ of the total loans of $\$ 44.85$ million. One MFI, Oxus Afghanistan, accounts for 4,245 loans, equivalent to $82 \%$ of all loans, of which 1,305 were to women. Oxus accounts for $92 \%$ of all FAIDA-recorded loans to women. Oxus was a recipient of a FAIDA grant of $\$ 300,000$, which it used to leverage a loan of $\$ 3$ million from MISFA.

Although FAIDA records these loans as part of private finance mobilized with US government support, it should be noted that a large part of the loan fund comes from the 
MISFA loan and Oxus's own resources. This issue is elaborated further under Evaluation Question 6. Table 6 gives a breakdown of loans generated by institution, gender, and amount.

\section{Table 6: Private Financing Mobilized}

\begin{tabular}{|c|c|c|c|c|c|}
\hline & Lending Institution & $\begin{array}{c}\text { Total } \\
\text { Beneficiaries } \\
\end{array}$ & $\begin{array}{c}\text { Total Loans } \\
\text { Approved } \\
\end{array}$ & $\begin{array}{c}\text { No. of } \\
\text { Female } \\
\text { Borrowers } \\
\end{array}$ & $\begin{array}{c}\text { Loans to } \\
\text { Women } \\
\text { Borrowers } \\
\end{array}$ \\
\hline 1 & Afghan Rural Finance Company & 94 & 11.217 .000 .00 & \multirow{9}{*}{$\begin{array}{l}11 \\
33\end{array}$} & \multirow{9}{*}{$\begin{array}{l}226,000.00 \\
946,924.20 \\
600,000.00\end{array}$} \\
\hline 2 & Afghanistan International Bank & 126 & $3,654,966.89$ & & \\
\hline 3 & Agricultural Development Fund & 21 & 9.631 .403 .00 & & \\
\hline 4 & Alfalah Bank & 1 & $1,300,000.00$ & & \\
\hline 5 & Azizi Bank & 8 & $7,500,000.00$ & & \\
\hline 6 & FINCA & 38 & $176,560.00$ & & \\
\hline 7 & FMFB & 125 & $3,559,285.21$ & & \\
\hline 8 & Ghazanfar Bank & 8 & 1.620 .000 .00 & & \\
\hline 9 & IIFC & 9 & $29,100.00$ & & \\
\hline 10 & Islamic Investment \& Finance Cooperatives & 449 & 667.966 .88 & 17 & $11,958.82$ \\
\hline 11 & Mutahid & 12 & $14,730.66$ & 9 & $6,130.66$ \\
\hline 12 & OXUS & 2 & 3.400 .00 & 1 & 400.00 \\
\hline 12 & OXUS Afghanistan & 4,245 & $5,475,705.59$ & 1,304 & $1,137,983.89$ \\
\hline & Grand Total & 5,138 & 44.850 .118 .23 & 1.410 & 3.012 .622 .89 \\
\hline & Proportion of Loans to Women & 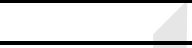 & $\sqrt{2+2}$ & $27 \%$ & $7 \%$ \\
\hline
\end{tabular}

Source: FAIDA Secondary Data

With the advent of microfinance, more women are now accessing loans. Data published by the AMA indicates that women constitute $39 \%$ of total active borrowers, equaling 168,176 borrowers, at its 14 MFI members. ${ }^{1}$ Most MFIs are adopting gender-friendly policies, including hiring more female loans officers and offering Zahra, a women-specific loan product administered by Oxus Afghanistan. Oxus has also adopted the use of group loans for women to overcome the challenges they face in securing loans. By their nature, microfinance loans tend to be small, short in duration, and expensive, with MFIs charging 18-24\% interest rates.

The Evaluation Team held a gender-specific FGD in the project regions in which 31 women participated. Asked if FAIDA had assisted them in any way in securing conventional or Sharia-compliant loans, eight of the participants had received conventional loans, while five women confirmed having received Sharia loans. Of the 57 participants in the matchmaking FGD, 43 of them ( 31 men and 12 women) had received loans both conventional and Sharia loans. Table 7 gives a breakdown of matchmaking FGD participants' loans by type of loan, gender, and region. There were no female participants in the FGD in Nangarhar, and only one with no loan in Kandahar.

\footnotetext{
${ }^{1}$ Microview - a quarterly Update on Development Finance Outreach in Afghanistan
} 
Of the participants who received loans, more received conventional than Sharia-type loans. Only three women received Sharia loans, while nine received conventional loans. Although there is generally a higher demand for Sharia-compliant loans, the practice among many MFIs seems to be to grant conventional loans. Some women said their families refused to let them borrow because of issues related to the payment of interest rates. More awareness on the availability of Sharia products is needed.

Table 7: Matchmaking FGD Loan Recipients by Type of Loan, Gender, and Region

\begin{tabular}{|l|c|c|c|c|c|c|}
\hline FGD Regions /Type of Loans & Balkh & Herat & Kabul & Kandahar & Nangarhar & Grand Total \\
\hline Sharia & 2 & 1 & 0 & 0 & 0 & $\mathbf{3}$ \\
\hline Convetional & 2 & 3 & 4 & 0 & 0 & $\mathbf{9}$ \\
\hline Total Fe male Borrowers & $\mathbf{4}$ & $\mathbf{4}$ & $\mathbf{4}$ & $\mathbf{0}$ & $\mathbf{0}$ & $\mathbf{1 2}$ \\
\hline Sharia & 0 & 1 & 0 & 5 & 9 & $\mathbf{1 5}$ \\
Convetional & 3 & 3 & 1 & 4 & 5 & $\mathbf{1 6}$ \\
\hline Total Male Borrowers & $\mathbf{3}$ & $\mathbf{4}$ & $\mathbf{1}$ & $\mathbf{9}$ & $\mathbf{1 4}$ & $\mathbf{3 1}$ \\
\hline Grand Total & $\mathbf{7}$ & $\mathbf{8}$ & $\mathbf{5}$ & $\mathbf{9}$ & $\mathbf{1 4}$ & $\mathbf{4 3}$ \\
\hline
\end{tabular}

Source: FAIDA Secondary Data

\section{d. Women's Opportunities for Economic and Professional Growth}

To give women opportunities for economic and professional growth, FAIDA supported internship programs for female professionals in finance, business, and government. The internships for women in finance and business are completed, but those for government are ongoing. A summary of the completed internship programs and number of participants is given in Table 8.

Table 8: Numbers of Participants in Internships

\begin{tabular}{|l|c|c|c|}
\hline Type of Institution & $\begin{array}{c}\text { Total Number } \\
\text { Attached }\end{array}$ & $\begin{array}{c}\text { Total Number } \\
\text { Placed }\end{array}$ & Current Status \\
\hline Government Internships & 60 & & - \\
Financial Institutions Attachments & 295 & 194 & Ongoing \\
\hline Total Attachments /Placement & $\mathbf{3 5 5}$ & $\mathbf{1 9 4}$ & \\
\hline
\end{tabular}

Source: FAIDA Evaluation Tools

Female participants in the internship program were selected through AIBF, and were attached to FIs for three-to-six months. The interns received training from AIBF, and on-the-job skills development from the respective FIs. To the interns, the attachments were very beneficial, as $194(66 \%)$ of those who interned at financial institutions were eventually employed. Eighteen of the women were not interested in placement, while others were continuing their studies or opted to do other things. Some of the FIs interviewed by the Evaluation Team, however, found the interns' qualifications not applicable to their needs. Hence, there is need to improve the selection process to make it more relevant to the financial sector job requirements. Effectively, given the low number of women working in the professional field, the objective should be to ensure that these internships transform into employment for all willing interns. 


\section{Mobile Network Operators ANd MobiLe Money}

\section{a. Technical Assistance to Mobile Network Operators}

Under the branchless Banking and Mobile Money Component, FAIDA was supposed to provide technical and financial assistance to Afghanistan's mobile network operators (MNOs) to introduce innovative new products and services and expand the use of mobile money. The size of the grants provided to MNOs by institution and purpose is given in Table 9.

Table 9: Grants Awarded to Mobile Network Providers

\begin{tabular}{|c|c|c|c|c|}
\hline $\begin{array}{c}\text { Mobile Network } \\
\text { Operator }\end{array}$ & $\begin{array}{l}\text { Original Grant } \\
\text { Amount in } \$\end{array}$ & Purpose & Start Date & Status \\
\hline $\begin{array}{l}\text { Etisalat } \\
\text { Afghanistan }\end{array}$ & $680,243.78$ & $\begin{array}{l}\text { Mobile payments for the supply of } \\
\text { electricity in Afghanistan }\end{array}$ & 1-Dec-11 & Closed \\
\hline $\begin{array}{l}\text { Etisalat } \\
\text { Afghanistan }\end{array}$ & $290,300.00$ & $\begin{array}{l}\text { Implementing business opportunities, } \\
\text { training and other services for Women in } \\
\text { Afghanistan }\end{array}$ & 20-Mar-13 & Closed \\
\hline Roshan /M-Paisa & $347,813.08$ & $\begin{array}{l}\text { M-Paisa ecosystem implementation for } \\
\text { Mutahid }\end{array}$ & 1-Nov-11 & Closed \\
\hline $\begin{array}{l}\text { Afghan Wireless } \\
\text { Communication } \\
\text { Company (AWCC) }\end{array}$ & $994,500.00$ & $\begin{array}{l}\text { Biometric Customer Registration Initiative } \\
\text { and Salary Payment Program }\end{array}$ & 1-Sep-12 & Closed \\
\hline $\begin{array}{l}\text { Afghanistan } \\
\text { Payments System }\end{array}$ & $312,939.80$ & $\begin{array}{l}\text { Supporting of Afghanistan Payments System } \\
\text { (APS) Initiative }\end{array}$ & 1-Feb-15 & Active \\
\hline MTN Afghanistan & $919,075.20$ & $\begin{array}{l}\text { Mobile Money expansion to the urban/rural } \\
\text { population }\end{array}$ & 28-Nov-11 & Terminated \\
\hline
\end{tabular}

Source: FAIDA Secondary Data

\section{b. MNOs' Performance in Introducing Innovative New Products and Services}

FAIDA launched a better-than-cash university competition whereby eight innovative products were identified. Each MNO was given two of the winning innovations for further development and promotion. The Evaluation Team visited several of the MNOs to determine the status of the assigned innovations and the use to which they had applied the grant funds. Information gathered during interviews with MNOs shows that none of the eight innovations were developed beyond the identification stage, for the reasons explained below.

Etisalat: Etisalat received two innovations, purchasing goods from supermarkets and paying traffic and vehicle registration fees, both of which were not developed further. Currently, its mHawalah system has 200 clients, including five women-owned agencies with about 40,000 customers. The MNO has an electrical bills and salary payment platform through mobile money. It is also looking into tapping into tax payments, such as rental tax and rental payments. According to Etisalat, more awareness is needed, as many people do not understand mobile money. 
Roshan/M-Paisa: Roshan received two innovations from FAIDA: i) cooperative members on loans disbursements; and ii) passport and traffic fees. The FAIDA grants to Roshan were intended to support some road shows and to further develop the MPaisa platform, which could be used by MFI borrowers in receiving and repaying loans. None of these were implemented because, even after seven years of experience, the MPaisa concept in Afghanistan has proved unprofitable. The MPaisa market was concentrated in Kabul, Herat, and Mazar-e Sharif. According to the Roshan, mobile money usage in Afghanistan is dependent on donor projects and on the salaries of clients who have some level of financial sophistication. Hence, there is a need to increase participation. According to the MNO, the technology model in place is incompatible with the market, and the industry would need $\$ 30$ $\$ 40$ million investment, which can only be achieved through the participation of all MNOs. As far as agents are concerned, the MNO felt they had enough qualified agents and did not need the FAIDA-supported matchmaking event for agents.

Afghan Wireless Communication Company (AWCC): Of all the MNOs interviewed, AWCC was the most progressive. AWCC received two of the eight innovative concepts: i) businesswomen selling their handicrafts and products; and ii) purchasing construction materials in rural areas. None has been implemented because, as communicated to the Evaluation Team, AWCC is focused on building its infrastructure at the moment. The telecom has been in the mobile money business for one year and claims it would not have been interested in entering the market without FAIDA funding, due to the high capital costs involved. FAIDA supported AWCC to obtain a license for mobile money. AWCC informants feel they are now in a better position to support access to finance and assist the unbanked populations. By the time of the interview with the Evaluation Team, AWCC had 20,000 customers in 26 provinces, including 7-9 corporate customers and 4,000-5,000 payroll clients.

AWCC was also in the process of venturing into electricity bills payment in partnership with the New Kabul Bank (NKB), and was also piloting a salary payment system with the Ministry of Finance, to transfer salaries of the police working in remote parts. There are, however, regulatory constraints to be overcome in salary management, as the current law limits the deposit of government employee salaries only to bank accounts. There is need to revise regulations to allow salaries to be deposited into banks and/or mobile money. AWCC has been engaged with World Food Program (WFP) since 2014 in an innovative relief voucher system involving 7,000-8,000 beneficiaries, and is targeting 68,000 families in seven provinces.

According to the MNOs, FAIDA has been instrumental in lobbying regulators to remove obstacles in a way that they could not have managed on their own. There was still a need, however, for DAB to support the sector by reducing the risk for participants and promoting innovation. They challenged FAIDA to allocate grants on the basis of each MNO's performance, not just on basis of its existence. They requested that grants not utilized be reallocated to high-performing MNOs. A major criticism leveled at FAIDA's approach is that while MNOs are business-driven, and investments are governed by anticipated returns and 
long-term sustainability, FAIDA was more concerned with the rate at which the grant was being utilized. AWCC requested more collaboration and regular meetings between FAIDA and MNOs. According to them, the biggest challenge is the general public's lack of awareness of the benefits of using the mobile money system.

Afghanistan Payment System (APS): FAIDA's grant to APS was extended in October 2014, and was used to procure computers, office equipment, and air conditioners. In addition to FAIDA, the Evaluation Team was informed that the World Bank is also supporting APS's data center in its endeavor to make it a "switch" for banking transactions in Afghanistan and from Afghanistan to other countries. APS was generally happy with FAIDA's support, although informants claimed that it took long to access.

MTN Group: The Evaluation Team was not able to meet with MTN, but learned it was assigned two of the innovations: i) payment of university fees; and ii) payment of municipal tax. The Evaluation Team learned that MTN opted out of the mobile money initiative because the company found the Afghan environment is not ready for its adoption and lacks the necessary infrastructure.

\section{c. Challenges to Mobile Money Penetration}

In November 2013 FAIDA commissioned "Market Research on Mobile Money in Afghanistan," by Altai Consulting. The aim of the study was to support key stakeholders in designing the right strategies to boost mobile money penetration and usage in Afghanistan. Unfortunately, the study ended after FAIDA had committed grants to the MNOs. Had the study been much earlier, the results would have guided FAIDA on appropriate interventions, if any, that were needed to support the growth of mobile money in Afghanistan.

The study found that only 5\% of SIM owners in Afghanistan subscribe to mobile money, and only two-thirds of this group performs any functional transactions, with most services essentially not used at all. Mobile money users were predominantly recipients of funds who preferred to withdraw money from banks even if non-bank agents are easier to reach. Most of them were forced by employers to subscribe in order to receive their salaries, but would have preferred to be paid in cash.

Fifty-six percent of non-users interviewed indicated they would consider subscribing to mobile money, but are unfamiliar with its services and benefits. Business owners were often skeptical of mobile money. A lack of savings and need for financial services, low awareness, and perceptions that mobile money is complicated and un-Islamic, were all identified as barriers to mobile money market penetration. Respondents also suggested a critical mass of users as necessary for them to be convinced to subscribe.

Access to mobile money agents was also identified as a major issue, as well as the reputation and liquidity of agents, in particular non-bank agents. Mobile money agents reportedly have very little incentive to promote the service due to the low use of mobile money, which 
jeopardizes their profitability, since withdrawal fees are caped. During the FGD, the Evaluation Team spoke to 18 (17 male and 1 female) agents working with AWCC, Etisalat, Roshan, and MTN and sought their views on the state of mobile money. Despite being trained and oriented by the MNOs, most dealers were frustrated by the lack of follow-up and support by respective MNOs. The agents also expressed frustration with the down turn in the mobile money technical systems, which took long to complete transactions, creating fear and mistrust between users and agents. The Team was told that sometimes it took days to complete a single transaction. The other problem is that the system is in English, which is not well-understood by the agents and clients. Consequently, many agents have opted to withdraw from the business.

Despite substantial support in the form of grants, the mobile money initiative has not succeeded to the extent anticipated. The MNOs lack of interest in investing in the sector, except when nudged by FAIDA by way of grants, is in itself an indication that they do not have confidence in the viability of mobile money. The sector lacks the required infrastructure and policies to guide its growth. Lack of security in most parts of the country has also been a challenge, as some of the MNOs have reported the destruction of their infrastructure, resulting in heavy financial loses. The MNOs are unable to access their infrastructure in some parts of the country.

FAIDA should not push its own agenda but rather allow the MNOs to lead the initiative based on their best business practices. Some international MNOs have implemented similar projects in other parts of the world, and being profit-driven, they know when the business environment is ripe for certain investments to take place. FAIDA should consider Altai Consulting's recommendations on how to boost penetration and usage of the services, including:

1. Focus on businesses and government to build a critical mass of mobile money users.

2. Increase awareness of the service and educate potential customers.

3. Develop a customer friendly and easy to access interface in local languages.

4. Address agent liquidity issues and train agents to ensure better service.

5. Enable inter-operability of MNOs

\section{ENABLING ENVIRONMENT}

\section{a. Effectiveness of Creating an Enabling Environment for Private Sector-Led Financial Sector Development}

FAIDA intended to work with a broad range of retail financial institutions, products, and delivery models, and accommodate diverse goals within Afghanistan's financial sector. This approach is both a strength and weakness of the program. The flexibility allowed FAIDA to engage in many aspects of the financial sector, but this also proved to be a weakness in that it makes it difficult for evaluators to determine the extent of FAIDA's success. 
The targeted policy interventions geared at improving the enabling environment for private sector-led financial sector development were to be implemented under the regulatory component of the project. This included improving the regulatory environment and capacity, including some assistance to the Central Bank. Under Section 2, the report highlighted FAIDA's support in building the knowledge and management infrastructure of intermediary organizations as a way of enhancing their advocacy capacity to build an enabling environment for financial sector development. The initiative has had some level of success, but the institutions in question (ABA, AMA, AIBF, etc.) still face many challenges and are far from being sustainable.

As far as the policy environment is concerned, the inability of FAIDA to engage with the Central Bank hampered its ability to influence new or modifications to existing policies. FAIDA, however, set out to promote the ABA to become a strong, credible, and progressive organization that promotes best practices in the banking sector and sets efficiency and excellence standards. FAIDA strengthen ABA's ability to play a serious advocacy and coordination role for the banking sector, especially related to the Anti-Money Laundering (AML) and Combating the Financing of Terrorism (CFT) laws, and to evolve into a sustainable association. FAIDA had provided anti-money laundering (AML) training to the Central Bank before the ban was imposed. The most successful initiative so far was the transitioning the advocacy, communications, and lobbying functions from MISFA to AMA. The institution however, still faces legitimacy challenges, as some foreign banks, and even local banks are unwilling to make the required financial subscriptions to a level that would sustain the organization.

In the area of mobile money, FAIDA was supposed to support the development of favorable policies that would govern mobile money and enhance the enabling environment for the effectiveness and efficiency of the mobile money industry. Section 4 reviewed the effect of FAIDA's technical assistance to Afghanistan's mobile network operators. Not much was achieved by the MNOs in furthering the use of mobile money. The sector faces many challenges and remains unprofitable to attract investment from the MNOs.

\section{Matchmaking Events}

\section{a. Overview}

Under the enterprises component, FAIDA worked with partner financial institutions in facilitating access to capital to complete the value chains and increase competiveness. FAIDA supported 95 matchmaking events, including business roundtables, innovation fairs, conferences, and workshops to link lenders to businesses (e.g., MSMEs) that need financing, and also to link businesses with other businesses, especially those in the import-export sector.

A total of 11,384 (7,259 male and 4,125 female) participants attended the matchmaking events, which were conducted in all provinces of the country. FAIDA reached out to chambers of commerce, private enterprises, industrial parks, private-sector associations, commercial banks, women's business development organizations, and others to identify and 
engage Afghan companies with viable lending prospects. Seventy-six percent of all participants came from the matchmaking activities numbered 1 and 2 in Table 10. The table gives a breakdown of the type of matchmaking events and trainings undertaken by FAIDA by number of participants and gender.

Table 10: FAIDA-Supported Events/ Activities by Number of Participant and Gender

\begin{tabular}{|c|l|c|c|c|c|}
\hline & Type of Eve nt/Activity & $\begin{array}{c}\text { Total } \\
\text { Events }\end{array}$ & Male & Fe male & $\begin{array}{c}\text { Total } \\
\text { Participants }\end{array}$ \\
\hline 1 & B2B & 41 & 2,259 & 889 & 3,148 \\
\hline 3 & Innovation & 3 & 4,402 & 1,061 & 5,463 \\
4 & Contract Farming Workshops & 9 & 287 & 156 & 443 \\
\hline 5 & Women's Access to Islamic Financing & 28 & 264 & 1,562 & 1,826 \\
& Finance Workshop & & & & 253 \\
6 & Business Planning Training for Businesswomen & 9 & 46 & 204 & 250 \\
\hline & Total & $\mathbf{9 5}$ & $\mathbf{7 , 2 5 9}$ & $\mathbf{4 , 1 2 5}$ & $\mathbf{1 1 , 3 8 4}$ \\
\hline
\end{tabular}

Source: FAIDA Secondary Data

The three India-Afghanistan Innovation Partnership Fairs generated the largest number of participants, 5,463 in all (4,402 men and 1,061 women). These were followed by events by the ABA, Access to Finance (A2F), and Business to Bank (B2B) roundtables across the country, attended by 3,148 participants (2,259 men and 889 women). The women's access to business opportunities and finance meetings attracted 1,826 participants, including 264 men, while the women's access to Islamic finance workshop had 254 participants. Information gathered from FAIDA indicates that financial institutions were well-represented in these forums to service the needs of MSMEs. For example, the second India-Afghanistan Innovation Partnership Fair event in Mazar-e-Sharif attracted eight banks and MFIs, in addition to 22 Indian businesses and 25 Afghan enterprises that showcased their products.

\section{b. Effectiveness of Matchmaking Events in Facilitating Loans to MSMEs}

Facilitation Process: The effectiveness of FAIDA's matchmaking events in facilitating linkages of MSMEs in need of financing to financial institutions can be measured by the number loans generated in total. The loan process starts with the development of a Concept Note $(\mathrm{CN})$ and/or a Business Plan on the prospective loan applicant, sometimes assisted by FAIDA. The CNs are then submitted to the lending institution where they go through a due diligence process. Some CNs become loans, while others are rejected. Secondary data analyzed shows that FAIDA developed a total of 1,308 CNs for prospective clients.

Although FAIDA tracks the number of loans approved and disbursed with US government support, tracking CNs and business plans was not part of its measurable indicators. Since a key objective of FAIDA was to meet the needs of MSMEs throughout Afghanistan, the Evaluation Team is of the view that to determine the efficiency of the matchmaking approach, 
FAIDA should have monitored the number of CNs, Business Plans, and business-to-business linkages that resulted from these events. The rate and number that translated into business contacts and into approved/disbursed loans to MSMEs would determine whether the approach was working or not.

If the efficiency of the matchmaking approach is measured by number of CNs developed $(1,308)$ against the number of people $(11,384)$ who attended all of FAIDA's 95 matchmaking and training events, then only $11 \%$ of the total participants requested loans. Although the matchmaking events were well-attended and helped create awareness of FAIDA's work, it seems many attendees were not interested in applying for loans. Considering that FIs were well-represented at these events, this indicates participants' general lack of interest in their services and low demand for loans.

The Evaluation Team cannot comment on outcome of the business-to-business matchmaking efforts, as there is no data on the number of businesses that were linked through the matchmaking events. Information received by the Team also indicates that FAIDA did not conduct exit surveys after the matchmaking events (B2Bs and Innovations), which would have enabled the project to assess the effectiveness of its approach in meeting the expectations of the attendees.

Matchmaking FGD: The Evaluation Team conducted FGD of beneficiaries of FAIDA's matchmaking events, and activities across the five project provinces. The FGD was attended by 45 people (18 men and 27 women). Table 11 provides a sample of the responses given by the 45 respondents about the type of assistance they received from FAIDA, as a measure of the success of the matchmaking events. In all, 28 participants (MSMEs), 62\% of the total, were able to secure a loan (11 Sharia and 17 conventional); 28 respondents indicated they were able to expand their businesses; and 23 respondents (51\%) had developed new business contacts.

It is the view of the Evaluation Team that the approach used by FAIDA to identify MSME invitees to the matchmaking events, through national and local businesses associations and bodies, was an effective way of bringing together a large numbers of clients, from multiple segments of the population, and geographic spread, and enabling them to access credit. Because of the prevailing security situation, however, the FAIDA matchmaking events were closed, and only invited MSME officials were allowed to attend. 
Table 11: Benefits of Matchmaking Events by Number of Respondents and Gender

\begin{tabular}{|l|c|c|c|c|}
\hline Type of Responses: & $\begin{array}{c}\text { Total Number of } \\
\text { Respondents }\end{array}$ & $\begin{array}{c}\text { \% of } \\
\text { Total }\end{array}$ & Female & Male \\
\hline Total Respondents & $\mathbf{4 5}$ & $\mathbf{1 0 0}$ & $\mathbf{2 7}$ & $\mathbf{1 8}$ \\
\hline Non-Agricultural Sector & 36 & 80 & 20 & 16 \\
\hline Agricultural Sector & 8 & 18 & 4 & 4 \\
\hline Assisted by FAIDA in completing loan application (Yes) & 27 & 60 & 10 & 17 \\
\hline Assisted by FAIDA in developing Concept Notes (Yes) & 25 & 56 & 9 & 16 \\
\hline Received conventional loan & 17 & 38 & 9 & 7 \\
\hline Received Sharia-type loan & 11 & 24 & 4 & 7 \\
\hline Developed new business contacts & 23 & 51 & 9 & 14 \\
\hline Was able to expand their businesses & 28 & 62 & 15 & 13 \\
\hline Hired more people & 18 & 40 & 8 & 10 \\
\hline Would they attend another FAIDA event if invited (Yes) & 43 & 96 & 23 & 18 \\
\hline
\end{tabular}

Source: FAIDA Evaluation Tools

Because of the low attendance in the evaluation FGD and the mixed responses, the Evaluation Team is unable to draw any conclusions from them. There are, however, some FGD participants who were of the view that FAIDA would have achieved more by working with a few businesses exclusively rather than engaging with a wide number of participants through the matchmaking events. The Team noted that participants in the innovation fairs expected to make sales rather than use them to network and develop long-term relationships. Thus, some of the exhibitors in the FGD complained they were not able to sell their products at the fairs, while others were of the view that the high cost of hiring space at such fairs was prohibitive for their small businesses.

Some matchmaking participants in the FGD found the workshops and seminars effective in bringing large and small businesses together. Some small business owners reported greatly benefitting from the presentations made by big businesses, financial institutions, and FAIDA on how to develop new markets, on the benefits of keeping good financial records, etc. One construction company owner said that before attending a matchmaking conference in the US, he was using Russian standards, but have since adopted very strong American construction management standards. According to him, it was up to the businesses to decide how to use the information acquired from these events. Some businesses expected FAIDA to hand-hold them in following-up on their new contacts and developing new business networks, which was not possible. Participants suggested that future matchmaking programs bring some international businesses to demonstrate the use of new technologies and to introduce new business ideas that can help Afghanistan reduce its reliance on imported goods.

Loan Count: According to FAIDA's amount of private financing mobilized tracker, a total of 5,138 loans (3,728 to men and 1,410 to women), amounting to $\$ 44.85$ million were generated through FAIDA's various matchmaking events and other methods used in linking prospective 
MSME borrowers to FIs. Table 12 gives a breakdown of the total loans facilitated through FAIDA by financial institution, amount, and gender.

\section{Table 12: Loans Facilitated through Matchmaking Events}

\begin{tabular}{|c|c|c|c|c|c|c|}
\hline & Financial Institutions & Loan amount & $\begin{array}{c}\% \\
\text { Amount }\end{array}$ & $\begin{array}{c}\text { Number } \\
\text { Male }\end{array}$ & $\begin{array}{c}\text { Number } \\
\text { Female }\end{array}$ & $\begin{array}{c}\text { Total } \\
\text { Borrowers }\end{array}$ \\
\hline 1 & Afghan Rural Finance Company & $11,217,000.00$ & 25 & 87 & 7 & 94 \\
\hline 2 & Afghanistan International Bank & $3,654,966.89$ & 8 & 101 & 25 & 126 \\
\hline 3 & Agricultural Development Fund & $9,631,403.00$ & 21 & 18 & 3 & 21 \\
\hline 4 & Alfalah Bank & $1,300,000.00$ & 3 & 1 & & 1 \\
\hline 5 & Azizi Bank & $7,500,000.00$ & 17 & 8 & & 8 \\
\hline 6 & FINCA & $176,560.00$ & $\mathbf{0}$ & 27 & 11 & 38 \\
\hline 7 & FMFB & $3,559,285.21$ & 8 & 92 & 33 & 125 \\
\hline 8 & Ghazanfar Bank & 1.620 .000 .00 & 4 & 8 & & 8 \\
\hline 9 & IIFC & $29,100.00$ & $\mathbf{0}$ & 9 & & 9 \\
\hline 10 & Islamic Investment \& Finance Cooperative & s $\quad 667,966.88$ & 1 & 432 & 17 & 449 \\
\hline 11 & Mutahid & $14,730.66$ & $\mathbf{0}$ & 3 & 9 & 12 \\
\hline 12 & OXUS & $3,400.00$ & $\mathbf{0}$ & 1 & 1 & 2 \\
\hline & OXUS Afghanistan & $5,475,705.59$ & 12 & 2941 & 1304 & 4245 \\
\hline & Grand Total & $44,850,118.23$ & 100 & 3728 & 1410 & 5138 \\
\hline
\end{tabular}

Source: FAIDA Secondary Data

Table 12 shows that the Afghan Rural Finance Company had the largest loan amount $(\$ 11.22$ million), followed by the Agricultural Development Fund (ADF) with 21 loans valued at $\$ 9.63$ million. Of the 5,138 loans, 4,245 borrowers (2,941 men and 1,304 women), equivalent to $83 \%$ of total, received loans from one MFI - Oxus Afghanistan. Although Oxus Afghanistan accounts for $83 \%$ of all borrowers, the loans tend to be small and many, totaling $\$ 5.5$ million, $12 \%$ of the total loans generated. FAIDA records all loans generated by Oxus as facilitated through their effort. This does not seem right, considering that the link between FAIDA and Oxus Afghanistan is a $\$ 300,000$ grant used to recapitalize the organization. Oxus Afghanistan used the grant to leverage a loan of $\$ 3$ million from MISFA, from which it rolled out the loans.

If the 4,245 loans generated by Oxus Afghanistan were to be removed from the tally, then FAIDA's matchmaking would account for 893 loans valued at $\$ 39$ million, which is $88 \%$ of total value of loans generated, and $68 \%$ of the $1,308 \mathrm{CNs}$ developed by FAIDA (as not all $\mathrm{CNs}$ result in loans). If we consider the 893 loans as what was effectively generated from the 11,384 participants who attended the 95 matchmaking events, this would be $7.8 \%$ of total participants. Based on this analysis, FAIDA's matchmaking approach cannot be considered to have been very successful, as it resulted in few loans, albeit with a higher value equivalent to $88 \%$ of the total loan value of $\$ 44.85$ million. It is the view of the Evaluation Team that facilitated loans should be only those for which FAIDA staff were involved in developing the CNs $(1,308)$ and linking the MSMEs to FIs.

End-Borrowers FGD Perspective: The Evaluation Team conducted a FGD for end borrowers, attended by 57 people. Table 13 gives a breakdown of total FGD end-borrower participants by the type of event attended that linked them to an FI. It is noted that a large 
number of those surveyed (26) had attended more than three of FAIDA's matchmaking events. Efforts should be made to diversify beneficiaries so that more MSMEs can benefit from the wide range of US government support. Most participants who received loans, however, appreciated the role played by FAIDA. Respondents indicated that FAIDA assisted them in developing CNs and even in completing loan applications. They felt that the loan process was simplified and faster with FAIDA's assistance. The Evaluation Team notes that FAIDA's influence on respective FIs ends with the delivery of CNs, as each has its own rules and regulations to follow in approving or rejecting a proposal.

\section{Table 13: FGD End Borrowers Linked to FIs}

\begin{tabular}{|c|l|c|}
\hline No. & \multicolumn{1}{|c|}{ Responses Given by Participants } & No. \\
\hline $\mathbf{1}$ & Attended FAIDA's Workshop & 2 \\
$\mathbf{2}$ & Attended Business to Bank Roundtable & 2 \\
$\mathbf{3}$ & Attended Business to Business Roundtable & 2 \\
$\mathbf{4}$ & FAIDA assistance in developing a business loan application & 7 \\
$\mathbf{5}$ & FAIDA is currently assisting me in developing my business & 8 \\
\hline $\mathbf{6}$ & Concept notes & 7 \\
$\mathbf{7}$ & Fon-Responsive & 1 \\
$\mathbf{8}$ & Grant and Workshop & 1 \\
$\mathbf{9}$ & Attended None & 1 \\
$\mathbf{1 0}$ & Have participated in more than three events & 26 \\
\hline
\end{tabular}

Source: FAIDA Secondary Data

In Kabul, none of the seven participants in the FGD had applied for a loan, the reason being that during the matchmaking events the FIs promised them lower interest rates ranging between $9 \%$ and $10 \%$. It seems that when they applied for loans, higher rates were quoted. Some participants in the FAIDA matchmaking events had expected introductions to donors that would give them grants. This is a general problem that may explain the large attendance at matchmaking events and the low number of the $\mathrm{CNs}$, as many attendees were not keen on loans.

In Herat, the Evaluation Team met with 12 participants who attended matchmaking events but did not apply for loans. Another reason for the low demand included a lack of grace period for repaying the loans. Participants argued their businesses are small and cannot support repayments within 30 days of the loan, as scheduled by most FIs. Some participants felt that they lack proper financial systems that would enable them to monitor their businesses' cash flows, profits, and loan repayments. The lack of collateral is also a major constraint, although this does not apply to microfinance loans. An association in Herat with over 120 companies under its wing had issues with the interest charged on loans. Participants also did not consider the Islamic products offered to be genuine, as the banks were not willing to share losses. The Evaluation Team, however, noted that of the 57 people who attended the FGD, 43 of them had received either a Sharia or conventional loan. Table 14 gives a breakdown of those that attended the FGD by type of loan and gender. 
Table 14: FGD Borrowers by Loan Type, Region, and Gender

\begin{tabular}{|l|c|c|c|c|c|c|}
\hline FGD Regions /Type of Loans & Balkh & Herat & Kabul & Kandahar & Nangarhar & Grand Total \\
\hline Sharia & 2 & 1 & 0 & 0 & 0 & $\mathbf{3}$ \\
\hline Convetional & 2 & 3 & 4 & 0 & 0 & $\mathbf{9}$ \\
\hline Total Fe male Borrowers & $\mathbf{4}$ & $\mathbf{4}$ & $\mathbf{4}$ & $\mathbf{0}$ & $\mathbf{0}$ & $\mathbf{1 2}$ \\
\hline Sharia & 0 & 1 & 0 & 5 & 9 & $\mathbf{1 5}$ \\
\hline Convetional & 3 & 3 & 1 & 4 & 5 & $\mathbf{1 6}$ \\
\hline Total Male Borrowers & $\mathbf{3}$ & $\mathbf{4}$ & $\mathbf{1}$ & $\mathbf{9}$ & $\mathbf{1 4}$ & $\mathbf{3 1}$ \\
\hline Grand Total & $\mathbf{7}$ & $\mathbf{8}$ & $\mathbf{5}$ & $\mathbf{9}$ & $\mathbf{1 4}$ & $\mathbf{4 3}$ \\
\hline
\end{tabular}

Source: FAIDA Evaluation Tools.

Overall, FAIDA's matchmaking events did not generate the volume of loans for MSMEs anticipated. FAIDA failed to monitor the performance of the matchmaking events by use of exit surveys and counting the numbers of $\mathrm{CNs}$ and business plans developed, which would eventually result in loans to MSMEs. By failing to do so, FAIDA has not been able to gauge the effectiveness and efficiency of matchmaking events in linking MSMEs to FIs. In the absence of demand for loans, instead of casting the net wide, FAIDA should have opted to work with a few willing prospective borrowers with higher chances of obtaining loans and linking them to FIs.

On the issue of Islamic loan products, there seem to be a stalemate between the lenders and the public. Most borrowers surveyed do not think the products offered by lenders are compliant with Islamic law on issues of returns/interest and in sharing of losses. This is a deep-rooted belief that will continue to impede access to finance. While the ongoing debate is healthy, it is affecting demand for credit, and FIs will not intermediate where they are not guaranteed a good return. A lot of Islamic loan products have been developed or are in the process of being developed, yet confusion reigns. Rather than leaving the matter with donor projects or individual financial institutions, it is upon the Central Bank as custodians of the financial sector to use its authority in guiding the development of these products. The process should also focus on a few products that can be popularized rather than too many. A proper needs assessment of the financial sector to determine what exists, the form it is in, and where gaps still exists is required.

\section{CONCLUSIONS}

FAIDA's interventions have created 5,396 full-time equivalent jobs with program funds or with counterpart contribution. Over $70 \%$ of the FAIDA-achieved FTEs were generated by a single MFI (Oxus Afghanistan) indirectly through its loans to MSMEs. FAIDA did well in terms of enhancing the capacity of financial professionals, but had limited success in building advocacy skills of the financial sector beneficiaries. In this regard, FAIDA's support has been based on the expressed needs of respective financial sector players. As far as the policy environment is concerned, the ongoing ban on working with the Central Bank has hampered FAIDA's work in supporting new or updating regulations across all financial sectors and key institutions that would enhance an enabling environment for financial services development. 
Overall, FAIDA's matchmaking events were well-attended but did not generate the volume of loans for MSMEs and/or business links as anticipated. FAIDA should monitor performance of the matchmaking events by use of exit surveys, and counting the numbers of concept notes and business plans developed, which would eventually result in loans to MSMEs. FAIDA has made good effort to integrate women at all aspects of the project, as noted by the attempt to monitor gender performance in ten of its indicators. Responses from women who participated in the gender, matchmaking, and end-borrower FGDs show that women benefited from the loan support.

Despite substantial support in form of grants to MNOs, the mobile money initiative did not succeed to the extent anticipated. If FAIDA had requested the Altai Consulting study on mobile money prior to engaging in investing in the sector, it would have advised telecoms better on the approach to use and whether the investment was worthwhile or not. The lack of interest by MNOs to invest in the sector was in itself an indicator that they did not find it viable. FAIDA should not push its own agenda, but allow the MNOs to lead the initiative based on their best business decisions and practices. FAIDA should also consider the recommendation made in the Altai study on ways to boost penetration and on the usage of mobile money services.

\section{RECOMMENDATIONS}

Based on the findings and conclusions of this performance evaluation of FAIDA, the following recommendations are made:

\section{RECOMMENDATION}

ACTION

Job Creation (Evaluation Question 1)

1 Separate direct and indirect FTEs and report them as they are. In other words, report MFI-MSMEs generated FTEs as indirect and separate from FAIDA-support directly generated FTEs.

2 Standardize partner MFIs'/FIs' FTE calculations to make them comparable.

3 Reconsider the FAIDA-FTE reporting indicator, taking into account that the nature of some of the interventions being carried out do not necessarily result in additional jobs.

Advocacy and an Enabling Environment (Evaluation Questions 2 and 5)

1 Resolve the existing embargo on the Central Bank to open the way for USAID FAIDA and other US government projects to intervene effectively in supporting regulations that would create an enabling environment for a progressive and thriving financial sector Integration of Women (Evaluation Question 3)

1 Endeavor to identify more businesswomen and assist them through the FAIDA process of preparing their loan applications and documentation.

2 Gear future US government assistance toward finding solutions to the USAID 


\begin{tabular}{|c|c|c|}
\hline & $\begin{array}{l}\text { problems women face in accessing loans at reasonable rates, and in } \\
\text { sufficient amounts to be able to grow their businesses. }\end{array}$ & \\
\hline 3 & $\begin{array}{l}\text { Negotiate with and encourage employers to accept more female interns as a } \\
\text { way of empowering women to seek employment. }\end{array}$ & FAIDA \\
\hline 4 & $\begin{array}{l}\text { To improve incomes and ability of women to service loans, look into how } \\
\text { women can be assisted to establish marketing cooperatives as outlets for } \\
\text { marketing of their goods. }\end{array}$ & $\begin{array}{l}\text { FAIDA/ } \\
\text { USAID }\end{array}$ \\
\hline 5 & $\begin{array}{l}\text { On issue of internships, there is a need to improve the candidates' selection } \\
\text { process for the internship program, and make AIBF trainings relevant to the } \\
\text { sectors to which the interns are posted. }\end{array}$ & \\
\hline \multicolumn{3}{|c|}{ Mobile Network Operators (Evaluation Question 4) } \\
\hline 1 & $\begin{array}{l}\text { Allow MNOs to lead the expansion of mobile money services based on } \\
\text { their best business practices. The MNO as investors would know when the } \\
\text { time is ripe for Mobile Money investments to take off. }\end{array}$ & FAIDA \\
\hline 2 & $\begin{array}{l}\text { Consider implementing the recommendations made by Altai Consulting } \\
\text { study to boost penetration and usage of mobile money services in } \\
\text { Afghanistan. }\end{array}$ & FAIDA \\
\hline \multicolumn{3}{|c|}{ Matchmaking Events (Evaluation Question 6) } \\
\hline 1 & $\begin{array}{l}\text { Broaden the range of participants invited to matchmaking events and avoid } \\
\text { recycling same people in these functions/events. }\end{array}$ & FAIDA \\
\hline 2 & $\begin{array}{l}\text { Conduct an assessment of Islamic loan products across the financial sector } \\
\text { to determine what exists, the form it is in, where gaps exists, and } \\
\text { incorporate the Central Bank in the development of these products. }\end{array}$ & FAIDA \\
\hline 3 & $\begin{array}{l}\text { Review the computation of amount of private finance mobilized as it relates } \\
\text { to loans generated by Oxus Afghanistan. These are not directly linked } \\
\text { through FAIDA's efforts. }\end{array}$ & FAIDA \\
\hline 4 & $\begin{array}{l}\text { Monitor concept notes, business plans, and conduct exit surveys on the } \\
\text { matchmaking events as a way of gauging the effectiveness of the approach } \\
\text { in facilitating loans to MSMEs, and change tact and approach if need be. }\end{array}$ & FAIDA \\
\hline
\end{tabular}




\title{
VI. ANNEXES
}

1. SCOPE OF WORK

\author{
OFFICE OF ECONOMIC GROWTH AND INFRASTRUCTURE (OEGI) \\ \& \\ OFFICE OF PROGRAM AND PROJECT DEVELOPMENT (OPPD)
}

STATEMENT OF WORK

Final Performance Evaluation

OF

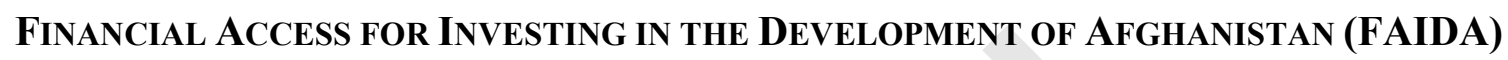

\section{PROGRAM INFORMATION}

\begin{tabular}{|l|l|}
\hline $\begin{array}{l}\text { Program/Project } \\
\text { Name: }\end{array}$ & $\begin{array}{l}\text { Financial Access for Investing in the Development of Afghanistan } \\
\text { (FAIDA) }\end{array}$ \\
\hline Contractor: & Chemonics Int. \\
\hline Contract \#: & 306-C-00-11-00531-00 \\
\hline Total Estimated Cost: & $\$ 108,258,374$ \\
\hline $\begin{array}{l}\text { Life } \\
\text { Program/Project: }\end{array}$ & February 2011-February 2016 (inclusive of 18 month extension) \\
\hline Active Provinces: & Nationwide \\
\hline $\begin{array}{l}\text { Mission Development } \\
\text { Objective (DO): }\end{array}$ & DO 1: Sustainable, Agricultural-led economic growth expanded \\
\hline $\begin{array}{l}\text { Linkage to Standard } \\
\text { Program Structure } \\
\text { (SPS): }\end{array}$ & Program Element 4.3.2: Financial Sector Capacity \\
\hline Required? & Required - large project \\
\hline Public or Internal: & Public \\
\hline
\end{tabular}

\section{INTRODUCTION}

USAID's Evaluation Policy encourages independent external evaluation to increase accountability and to inform program management, development strategy, and resource allocation. In keeping with this aim, this evaluation will assess FAIDA's performance between 2011 and 2014, in relation to its program goal, objectives, and results.

The FAIDA project employs a "financial system" approach, which works at the micro- and macro-levels to ensure that large numbers of micro, small, and medium enterprises (MSMEs) have access to a diverse range of financial services. At the micro-level, FAIDA works with 
retail financial institutions to ensure that large numbers of clients, multiple segments of the population, and a broad geographic sector have improved access to credit. At the macrolevel, FAIDA supports financial institutions' access to capital, bolsters technical support and educational services, and fosters advocacy capacity for the banking sector. Additionally, FAIDA is positioned to help the Government of Afghanistan develop and implement favorable policies that would improve the financial sector enabling environment.

\section{Background}

FAIDA has implemented a significant number of activities across all three main project components: (i) expanding the coverage of the formal financial system and developing innovative, culturally appropriate products for underserved markets (including the use of mobile money); (ii) improving institutional capacity and human capital; and (iii) improving the regulatory environment and capacity, including some assistance to Da Afghanistan Bank (Central Bank). FAIDA aims to support the creation of an enabling environment for policy, legal and regulatory matters to enhance transparency, facilitate expansion of the financial services, and establish the rules for engaging retail institutions in the financial sector. This will generate quality employment, with a special focus on MSME access to finance by strengthening civil society financial sector organizations and working with relevant business associations throughout Afghanistan.

\section{FAIDA's Development Hypothesis:}

By developing the capacity of a broad range of retail financial institutions, products and delivery models, diverse goals within Afghanistan's financial sector will be met, including achieving large number of clients, reaching multiple segments of clients and broad geographic coverage. Investment in the overall infrastructure of the financial system including enhanced access to growth capital, a market for technical support and education services, enhanced advocacy capacity and effective knowledge management infrastructure will help build a market that will ensure the long-term sustainability of these objectives. Investments in enhancing the enabling environment will also accelerate the development and expansion of a financial sector led by the private sector. Favorable policies that govern mobile money will increase technical capacity of financial and telecommunication institutions to meet the needs of the diverse population. All these interventions will support the enhanced functionality of financial institutions, an enabling environment for the private sector, effectiveness and efficiency of the mobile money industry. These will collectively contribute to a robust financial sector that can generate employment and meet the needs of Micro, Small and Medium Enterprises.

\section{FAIDA's Theory of Change:}

Afghanistan can expect to build a sustainable, diverse and inclusive financial sector that can generate and sustain quality employment to meet the needs of MSMEs, if:

(1) The Government of the Islamic Republic of Afghanistan and the private sector are assisted to develop the financial sector; 
(2) Afghan partners are helped to build capacity in delivering finance effectively, developing a legal framework and market infrastructure in which financial sector institutions create value that provides growth and employment opportunities for all Afghans;

(3) Technical assistance is provided to Afghanistan's mobile network operators for innovative mobile money products and services;

(4) Afghan women entrepreneurs are assisted directly by providing specially targeted business development trainings to enable them to gain access to financing and opportunities for economic and professional growth.

While FAIDA is intended to be a nationwide financial sector development project, it will support development of specialized regional strategies to meet local needs, with a particular focus on the south and east. The increased presence of impactful services in these nonpermissive regions will provide an alternative to destabilizing elements, while continued attention to Kabul and the north will enable FAIDA to build upon achievements to date in permissive areas where more traditional development assistance is required.

\section{Below is the progress to date:}

- 3,331 Full-Time Equivalent (FTE) jobs created.

- Business development services improved - 23,627 families have directly benefited from assistance provided by FAIDA.

- Capacity of private sector financial institutions increased - to date, FAIDA has supported 4,889 Afghan enterprises in obtaining loans totaling \$37,237,478 from different financing institutions in Afghanistan. Of these, 1,315 loans are for Afghan women enterprises with the loan amount totaling to $\$ 2,490,704$. Also, FAIDA facilitated $\$ 18$ million in loan applications for the private sector that are currently in the pipeline.

- $\quad \mathbf{2 , 4 1 0}$ employees of the financial sector (banks and micro finance institutions (MFIs)) participated in 258 financial sector trainings.

- 1,200 businesswomen from 34 provinces participated in 22 business and gender workshops called 'Women's Access to Business Opportunities and Finance.'

- 16 working groups established to address financial sector development issues; 58 public-private dialogue mechanisms utilized; and 49 comments on financial sector related laws and regulations provided.

- Direct technical support to microfinance institutions in Afghanistan provided.

- Technical assistance to enhance capacity and reach of mobile money and branchless banking provided.

- Capacity of Afghanistan Banks Association (ABA) and Afghanistan Institute of Banking and Finance (AIBF) build. 


\section{FAIDA strengthened capacity of financial industry associations by:}

- Supporting the Afghanistan Banks Association (ABA) to become strong, credible, and progressive organization that promotes best practices in Afghanistan banking sector and sets efficiency and excellence standards.

- Enhancing institutional capacity of the Microfinance Investment Support Facility for Afghanistan (MISFA) which is a second-tier lender to Micro Finance Institutions (MFIs) in Afghanistan. With FAIDA's support, MISFA developed a strategic plan to focus on expanding financial inclusion and to provide leadership to the microfinance sector.

- Providing technical and financial support to strengthened capacity of the Afghanistan Microfinance Association (AMA).

- Facilitating Afghanistan Institute of Banking and Finance (AIBF) in building its capacity to serve as a training hub for the country's financial sector. FAIDA also works with AIBF to identify opportunities for national and international accreditations and partnerships.

- Helping to launch the Afghanistan Insurance Association (AIPA) and working to build its capacity. Also, FAIDA provides technical assistance to the Afghanistan Insurance Authority (AIA) which is a regulatory body writhing the Ministry of Finance (MOF).

\section{PROGRAM GOALS AND OBJECTIVES}

USAID/Afghanistan FAIDA Results Framework

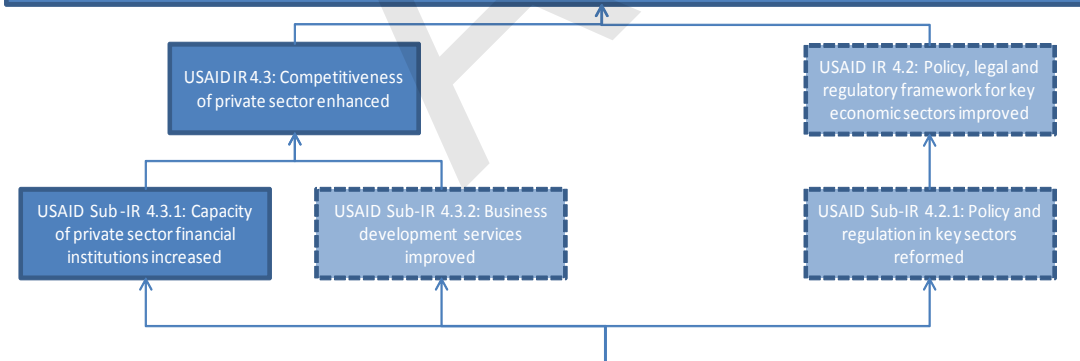

FAIDA Objective: To build a sustainable, diverse and inclusive financial sector that can generate and sustain quality employment, by meeting the needs of MSMEs
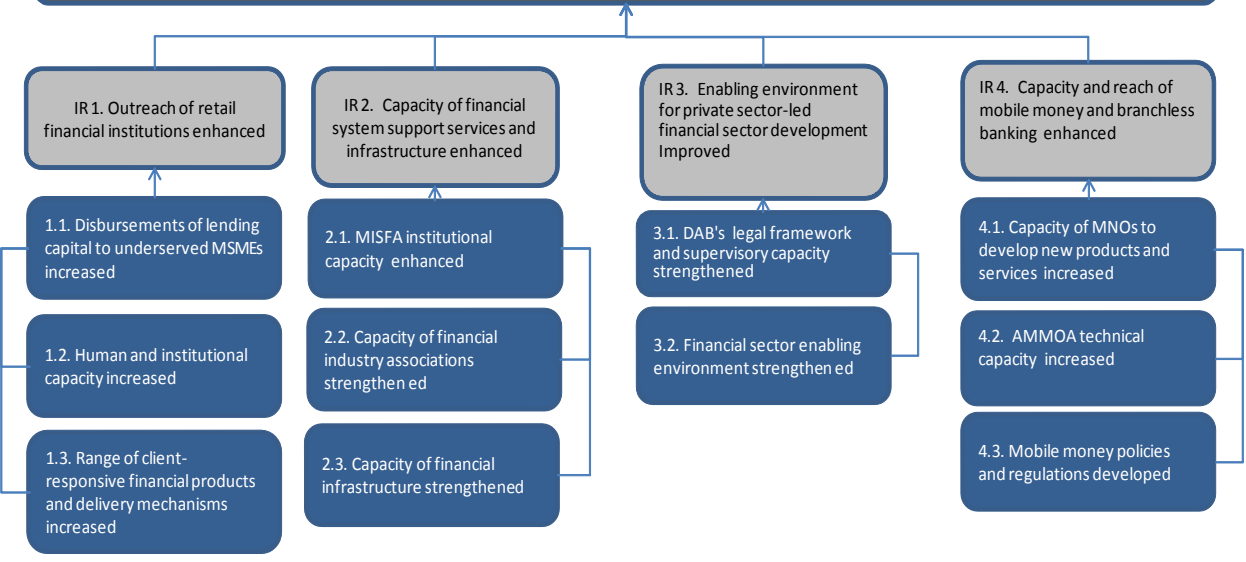
The overall objective of FAIDA is job creation through a sustainable, diverse, and inclusive financial sector that can meet the needs of MSMEs throughout Afghanistan. The expected results are:

Result 1: Enhanced outreach of retail financial institutions at the micro level (retail financial institutions)

Sub-Result 1.1 - Increased disbursement of lending capital to underserved MSMEs

Sub-Result 1.2 - Enhanced human and institutional capacity

Sub-Result 1.3 - Increased range of client-responsive financial products and delivery Mechanisms

Result 2: Enhanced capacity of financial system support services and infrastructure at the meso-level (financial market infrastructure)

Result 3: Improved enabling environment for private sector-led financial sector development at the macro-level (policy environment)

Result 4: Expanded financial inclusion using a combination of technical assistance, grants, and public-private partnerships to promote system functionality, awareness, and uptake of all forms of electronic payments, branchless banking and mobile money.

Gender Integration and Gender Equality: Gender equity support through availing women with opportunities at all levels in the financial sector.

\section{ACTIVITIES TO ACCOMPLISH PROGRAM GOALS AND OBJECTIVES}

- Enterprises Component: Works with partner institutions to provide tailored financial solutions where access to capital will complete value chains and increase competitiveness. Links lenders to businesses in need of financing.

- Banking Capacity Component: Enhances the capacity of financial professionals, and infrastructure organizations with assistance to build human and organizational capacity to strengthen Afghanistan's financial sector. Provides Islamic and conventional financial products to lenders and the private sector.

- Regulatory Component: Creates an enabling lending environment that reduces risk and increases certainty. Develops new or updated regulations across all financial sectors and key institutions.

- Branchless Banking and Mobile Money Component: Provides technical assistance to Afghanistan's mobile network operators to introduce innovative new products and services and expand the use of mobile money.

- Gender Mainstreaming Unit: Ensures that women are integrated in financial sector activities and are provided access to finance and opportunities for economic and professional growth. 


\section{PURPOSE OF THIS EVALUATION}

This evaluation is to assess the quality and effectiveness of FAIDA's interventions in the following three areas:

e. MSME jobs created as a result of FAIDA's activities

f. FAIDA's technical assistance and grants for sub-award recipients to build their institutional and human capacity and advocacy skills. These sub-awardees are: Afghanistan Banks Association (ABA), Afghanistan Microfinance Association (AMA), Afghanistan Institute of Banking and Finance (AIBF), and Afghanistan Insurance Personnel Association (AIPA)

g. Loans facilitated with support of U.S. government assistance through FAIDA, including for female borrowers and underserved MSMEs.

h. Regulatory component, including policy, legal, and regulatory frameworks, to determine the extent to which the objectives for this component were achieved.

The evaluation will also identify lessons learned and develop specific recommendations to improve project activities. The USAID Office of Economic Growth and Infrastructure (OEGI) intends to use the findings of this evaluation for more focused and target interventions through FAIDA during its last 18-month extension period, and to complement the design of new private sector development activities. The lessons learned will also benefit the larger USAID/Afghanistan mission and other donors working in the financial sector.

\section{EVALUATION QUESTIONS}

The evaluation questions are as follows:

7. How effective and efficient have FAIDA's interventions been in creating jobs for men and women in MSME enterprises, financial institutions, and business associations?

8. How successful has FAIDA's assistance been in enhancing capacity of financial professionals and building advocacy skills for the financial sector beneficiaries (e.g., ABA, AMA, AIBF, and AIPA)?

9. To what extent has FAIDA's interventions integrated women in the financial sector and provided access to finance and opportunities for economic and professional growth?

10. How effective has FAIDA's technical assistance to Afghanistan's mobile network operators been in introducing innovative new products and services and expanding the use of mobile money? 
11. What have been FAIDA's key achievements in improving the enabling environment for private-sector-led financial sector development, and how will they impact the sector in the long-run?

12. How successful were FAIDA's matchmaking events in linking financial institutions with MSMEs in need of financing (e.g. business roundtables, innovation fairs, conferences, workshops)?

\section{EVALUATION DESIGN \& METHODOLOGY}

The evaluation team will be responsible for developing an evaluation strategy and methodology that include a mix of qualitative and quantitative data collection and analysis approaches. The team has discretion to design and use the most appropriate evaluation tools though the approach should be participatory in both design and implementation. Close coordination with USAID/Afghanistan (OEGI) will be necessary to ensure that the evaluation team selects methods that are sustainable for use in conflict areas. The methodology will be presented as part of the draft work plan as outlined in the deliverables (Section XI) and included in the final report. Evaluation questions should examine outcomes for both women and men at the micro, meso, and macro levels to ensure that the project achieved the best results for all targeted beneficiaries. All data collected and presented in the evaluation report must be disaggregated by sex and geography. Lessons learned, quality of impact, and level of sustainability must be addressed by these variables. Analysis of successes or failures must be compared and contrasted as successful interventions in one province may not be successful in others. The evaluation design and methodology will be critically evaluated against the 'purpose of the evaluation' - most importantly its ability to provide actionable guidance to USAID for current and future programming.

The suggested methodology may include, but is not limited to:

a) Key interviews with USAID/Afghanistan's OEGI Staff, and field-based USG staff at Regional Platforms;

b) Interviews with implementing partner staff in Kabul and its Regional Coordinators;

c) Interviews with selected stakeholders; USAID Afghanistan will provide a list;

d) Consultations with other donors (e.g., The World Bank, International Financial Corporation (IFC), the Department for International Development (DFID), the Asian Development Bank (ADB)), and

e) Focus Group discussions and questionnaires with a sample of beneficiaries in targeted areas to determine perceptions of the MSMEs and financial sector beneficiaries (e.g. microfinance institutions, the central bank, local commercial banks, MSMEs, associations supported by FAIDA) on the value and quality of the technical assistance and training.

\section{Definition of Beneficiaries}

For the purposes of the evaluation, the FAIDA beneficiaries are defined as: 
- MSMEs trainees (Trainees of Business to Bank Roundtables, Gender Workshops and Mobile Money Workshops)

- MSMEs supported though loan facilitation

- Financial sector employees trained

- Financial sector professionals/supervisors trained

- Technical assistance recipient financial institutions

- FAIDA grantees (businesses, associations, mobile network operators)

\section{EXISTING PERFORMANCE INFORMATION SOURCES}

The USAID/OEGI team will provide to the Evaluation Team a wide range of documents on FAIDA for review prior to and upon arrival in the country.

Illustrative list of Documents for the Evaluation Team:

a) FAIDA Statement of Work and Modifications

b) FAIDA Work Plans

c) FAIDA Quarterly Reports

d) FAIDA Annual Reports

e) FAIDA Project monitoring Plans and other M\&E documents

f) FAIDA performance data

g) A contact list of the implementing partner's key personnel with email addresses and mobile phone numbers; other contact information as required.

h) Other Documents as required

\section{Secondary Sources of Data}

In order for the evaluation to proceed as efficiently as possible, the team, where possible, will conduct secondary analysis of data on FAIDA progress to date. As it is central to the evaluation, FAIDA will provide the data set from which it calculated the number of FTE jobs created to date. Other important data sets to be provided include but are not limited to the data set from which the number of families directly benefiting from improved business development services was calculated.

\section{Sampling frame for beneficiaries surveys}

Focus group discussions with beneficiaries should be prioritized for efficiency of the evaluation. However, if a short survey of beneficiaries is proposed and well justified, FAIDA will provide comprehensive lists, from which samples will be drawn of the following FAIDA beneficiaries:

- MSMEs and trainees from these organizations

- MSME participant lists for training events (Business to Bank Roundtables, Gender Workshops and Mobile Money Workshops).

- Financial sector organizations and trainees

- Financial institutions and related trainees

- FAIDA grantees 
The USAID/OEGI point of contact for the team is the FAIDA COR Abdullah Sawiz and FAIDA Alternative COR Nino Kumsishvili.

\section{EVALUATION TEAM COMPOSITION}

The Evaluation Team shall include evaluation and technical specialists with relevant experience particularly in public management reform in a conflict/post-conflict country. It is recommended that the team include two independent international and one high level Afghan expert with strong research and writing skills, and strong knowledge of local culture including an awareness of norms, subgroups, and interactions among groups, cultural practices and perspectives, as well as key gender issues.. Final selection of the members of the Evaluation Team is subject to approval by the FAIDA Contracting Officer Representative (COR) and the Contracting Officer (CO).

Evaluation Team Leader (Expat): The Team Leader (TL) shall possess strong leadership, and report writing skills and be an evaluation expert at least with at least seven years of program evaluation experience. Preferably the TL will have experience with USAID funded private sector programs. The TL shall possess at least a Master's degree, $\mathrm{PhD}$ preferred, in the area of private sector development, financial management, business administration, banking, or a related discipline. TL should be familiar with the USAID Evaluation Policy, and develop a standard, accurate, concise and evidence-based evaluation report in English. Afghanistan or regional country experience is preferred.

Private Sector Specialist (Expat): The Private Sector Specialist shall possess at least a Master's degree in business administration, financial management, banking, social science, or a related field. The specialist shall have at least five years' experience as private sector development or financial sector/banking development specialist, or similar field, and should be familiar with the USAID Evaluation Policy. Afghanistan or regional country experience and proficiency in English required.

Research Specialist (Afghan): The Evaluation Specialist shall possess at least a Bachelor's degree, and have applied evaluation experience including data collection and analysis. Experience and knowledge in assessing relevant data by using appropriate evaluation methodologies is required. The Evaluation Specialist should be familiar with the USAID Evaluation Policy. Afghanistan or regional country experience and proficiency in English and Dari/Pashto are required.

A statement of potential bias or conflict of interest (or lack thereof) is required of each team member.

\section{EVALUATION SCHEDULE}

The estimated time period for undertaking this Evaluation is 48 days, of which at least 40 days should be spent by expat Team Leader and Specialist in Afghanistan. The expat team members should arrive in Kabul no later than March 15, 2015. 
The evaluation team is authorized to work six days a week (regular work days in Afghanistan are from Sunday through Thursday). The team is required to evaluate FAIDA's activities in the following five locations: Kabul, Kandahar, Herat, Mazar, and Jalalabad.

\section{Illustrative LOE in days by activity:}

\begin{tabular}{|c|c|c|c|c|}
\hline Activity & $\begin{array}{l}\text { Expat } \\
\text { Team } \\
\text { Lead }\end{array}$ & $\begin{array}{l}\text { Expat. } \\
\text { Speciali } \\
\text { st }\end{array}$ & $\begin{array}{l}\text { Afghan } \\
\text { Researc } \\
\text { h } \\
\text { Speciali } \\
\text { st }\end{array}$ & $\begin{array}{l}\text { Total } \\
\text { Days }\end{array}$ \\
\hline $\begin{array}{l}\text { Document review, begin preparation on work plan, } \\
\text { draft questions, data analysis plan, suggested list of } \\
\text { interviewees }\end{array}$ & 2 & 2 & 2 & 6 \\
\hline Travel to and from Afghanistan & 4 & 4 & & 8 \\
\hline In-briefing with USAID & 1 & 1 & 1 & 3 \\
\hline Draft work plan & 2 & 2 & 2 & 6 \\
\hline Field Work & 20 & 20 & 20 & 60 \\
\hline Secondary Data Analysis & 5 & 5 & 5 & 15 \\
\hline & & & & \\
\hline Mid-point briefing & 1 & 1 & 1 & 3 \\
\hline $\begin{array}{l}\text { Data analysis, preliminary report and presentation to } \\
\text { USAID }\end{array}$ & 6 & 6 & 6 & 18 \\
\hline Draft final report and debrief to USAID & 5 & 5 & 53 & 9 \\
\hline Finalize Report & 3 & 2 & & \\
\hline Capacity Building & 2 & 2 & & 4 \\
\hline 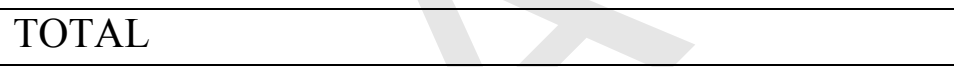 & 51 & 50 & 42 & 141 \\
\hline
\end{tabular}

Illustrative LOE in days by position:

\begin{tabular}{|l|l|l|l|l|l|}
\hline Position & $\begin{array}{l}\text { Remote } \\
\text { prep }\end{array}$ & $\begin{array}{l}\text { Travel } \\
\text { to/from } \\
\text { Kabul }\end{array}$ & $\begin{array}{l}\text { In- } \\
\text { Country }\end{array}$ & $\begin{array}{l}\text { Finalization } \\
\text { of Report }\end{array}$ & Total \\
\hline Expat Team Leader & 2 & 4 & 40 & 5 & 51 \\
\hline $\begin{array}{l}\text { Expat Evaluation } \\
\text { Specialist }\end{array}$ & 2 & 4 & 40 & 4 & 50 \\
\hline Afghan Specialist & & & 42 & & 42 \\
\hline Totals & 4 & 8 & 122 & 4 & 138 \\
\hline
\end{tabular}

\section{MANAGEMENT}

Checchi/SUPPORT-II will identify and hire the evaluation team, pending the COR's concurrence and $\mathrm{CO}$ approval, assist in facilitating the work plan, and arrange meetings with 
key stakeholders identified prior to the initiation of the fieldwork. The evaluation team will organize other meetings as identified during the course of the evaluation, in consultation with Checchi/SUPPORT-II and USAID/Afghanistan, OEGI team. Checchi/SUPPORT-II is responsible for all logistical support required for the evaluation team, including arranging accommodation, security, office space, computers, internet access, printing, communication, and transportation.

The evaluation team will officially report to Checchi's SUPPORT-II management. Checchi/SUPPORT-II is responsible for all direct coordination with USAID/Afghanistan/OPPD, through the SUPPORT II COR Daryl Martyris (dmartyris@state.gov). From a technical management perspective, the evaluation team will work closely with FAIDA COR Sawiz Abdullah: SawizAX@state.gov; FAIDA Alternative COR Nino Kumsishvili: Nkumsishvili@state.gov; and OPPD M\&E Charmaine Matovu: CVMatovu@state.gov. In order to maintain objectivity, OPPD’s Monitoring and Evaluation Unit will make all final decisions about the evaluation.

\section{DELIVERABLES AND REPORTING REQUIREMENTS}

1. In-briefing: Within $\mathbf{4 8}$ hours of arrival in Kabul, the Evaluation Team, will have an inbriefing with the OPPD M\&E unit and the OEGI/EG Team for introductions and to discuss the team's understanding of the assignment, initial assumptions, evaluation questions, methodology, and work plan, and/or to adjust the SOW, if necessary.

2. Evaluation Work Plan: Within 3 calendar days following the in-brief, the Evaluation Team Leader shall provide a detailed initial work plan to OPPD's M\&E unit and OEGI/EG. The initial work plan will include: (a) the overall evaluation design, including the proposed methodology, data collection and analysis plan, and data collection instruments; (b) a list of the team members and their primary contact details while incountry, including the e-mail address and mobile phone number for the team leader; and (c) the team's proposed schedule for the evaluation. USAID offices and relevant stakeholders are asked to take up to $\mathbf{2}$ days to review and consolidate comments through the SUPPORT II COR. Once the evaluation team receives the consolidated comments on the initial work plan, they are expected to return with a revised work plan within $\mathbf{2}$ days. The revised work plan shall include the list of potential interviewees and sites to be visited.

3. Mid-term Briefing and Interim Meetings: The evaluation team is expected to hold a mid-term briefing with USAID on the status of the assessment including potential challenges and emerging opportunities. The team will also provide periodic briefings and feedback on the team's findings, as agreed upon during the in-briefing. If desired or necessary, weekly briefings by phone can be arranged.

4. PowerPoint and Final Exit Presentation: The evaluation team is expected to hold a final exit presentation to discuss the summary of findings and recommendations to 
USAID. This presentation will be scheduled as agreed upon during the in-briefing. Presentation slides should not exceed 18 in total.

5. Draft Evaluation Report: The draft evaluation report should be consistent with the guidance provided in Section XIII: "Final Report Format." The report will address each of the issues and questions identified in the SOW and any other factors the team considers to have a bearing on the objectives of the evaluation. Any such factors can be included in the report only after consultation with USAID. The submission date for the draft evaluation report will be decided upon during the mid-term or exit briefing and submitted to OPPD's M\&E unit by Checchi. Once the initial draft evaluation report is submitted, the following deadlines should be followed:

a. OEGI/EG will have 8 working days in which to review and comment on the initial draft, after which point USAID/OPPD's M\&E unit will have 2 working days to review and consolidate all USAID comments (total of $\mathbf{1 0}$ working days). OPPD will submit the consolidated comments to Checchi.

b. The evaluation team will then have $\mathbf{5}$ working days to make appropriate edits and revisions to the draft and re-submit the revised final draft report to USAID.

c. OEGI/EG and the M\&E unit will have $\mathbf{1 0}$ working days after the submission of the second revised draft to again review and send any final comments.

6. Final Evaluation Report: The evaluation team will be asked to take no more than $\mathbf{3}$ days to respond/incorporate the final comments from OEGI/EG and OPPD. The Evaluation Team Leader will then submit the final report to OPPD. All project data and records will be submitted in full and should be in electronic form in easily readable format; organized and documented for use by those not fully familiar with the project or evaluation; and owned by USAID.

7. Capacity Building of Afghan Evaluation Team Members: The evaluation team will report to Checchi on how the capacity of local evaluation team members was built during this evaluation. Checchi will then consolidate this information together with capacity building from other evaluations and submit in the quarterly and annual reports to USAID.

\section{FINAL REPORT FORMAT}

The evaluation final report should be about 25 pages in length, not including annexes. It should be written in English, using Times New Roman 12 point font, 1.15 line spacing, and be consistent with USAID branding policy. The report should be structured as follows:

1. Title Page

2. Table of Contents

3. List of any acronyms, tables and/or figures

4. Acknowledgements or Preface (optional)

5. Executive Summary (3-5 pages)

6. Introduction 
a. Description of the project evaluated, including goal and expected results

b. Brief statement on purpose of the evaluation, plus a list of the evaluation questions

c. Description of the methods used in the evaluation (such as desk/document review, interviews, site visits, surveys, etc.), the rationale and location for field visits (if any), and a description of the numbers and types of respondents

d. Limitations to the evaluation, with particular attention to the limitations associated with the evaluation methodology (selection bias, recall bias, unobservable differences between comparator groups, etc.)

7. Findings

a. Describe findings, focusing on each of the evaluation questions and providing gender disaggregation where appropriate

b. Evaluation findings should be presented as analyzed facts, evidence, and data and not based on anecdotes, hearsay, or the compilation of people's opinions

8. Conclusions

a. Conclusions are value statements drawn from the data gathered during the evaluation process

9. Recommendations

a. Recommendations should be actionable, practical and specific statements for existing programming and for the design and performance of future programming

b. Each recommendation should be supported by a specific set of findings

c. Include recommended future objectives and types of activities based on lessons learned

10. Annexes

a. Evaluation Scope of Work

b. Methodology description (include any pertinent details not captured in the report)

c. Copies of all survey instruments and questionnaires

d. List of critical and key documents reviewed

e. Schedule of Meetings and sources of information (If confidentiality is a concern, the team should discuss and agree upon an approach with USAID)

f. Notes from key interviews, focus group discussions and other meetings

g. Documentation of any changes to the SOW or evaluation process

h. Statement of differences (if applicable)

i. One page briefer of findings, recommendations and lessons learned (optional)]

\section{REPORTING GUIDELINES}

- The evaluation report should represent a thoughtful, well-researched and wellorganized effort to objectively evaluate the validity of the project's hypothesis and the effectiveness of the project.

- Evaluation reports shall address all evaluation questions included in the statement of work. 
- The evaluation report will be written in highly professional English, free of grammatical and typographical error, and with professional formatting.

- The evaluation report should include the statement of work as an annex. Any modifications to the statement of work, whether in technical requirements, evaluation questions, evaluation team composition, methodology, or timeline need to be agreed upon in writing by the SUPPORT II COR.

- Evaluation methodology shall be explained in detail. All tools used in conducting the evaluation such as questionnaires, checklists and discussion guides will be included in an Annex in the final report.

- Evaluation findings will assess how results affected men and women.

- Limitations to the evaluation shall be disclosed in the report, with particular attention to the limitations associated with the evaluation methodology (selection bias, recall bias, unobservable differences between comparator groups, etc.).

- Evaluation findings should be presented as analyzed facts, evidence, and data and not based on anecdotes, hearsay, or the compilation of people's opinions. Findings should be specific, concise and supported by strong quantitative or qualitative evidence.

- Sources of information need to be properly identified and listed in an annex. If confidentiality is a concern, the team should discuss and agree upon an approach with USAID.

- Recommendations need to be supported by a specific set of findings.

- Recommendations should be action-oriented, practical, and specific, with defined responsibility for the action. 
2. WORK PlaN

FINAL WORKPLAN

FINAL PERFORMANCE EVALUATION

OF

FINANCIAL ACCESS FOR INVESTING IN THE DEVELOPMENT OF AFGHANISTAN

(FAIDA)

Submitted on:

May 7, 2015 
1. List of Acronyms Error! Bookmark not defined.

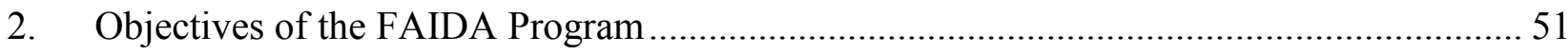

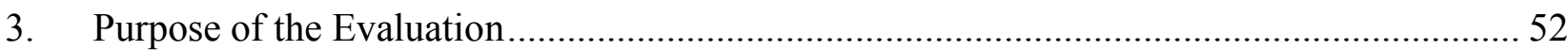

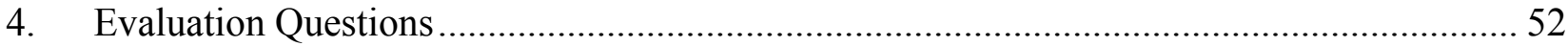

5. Evaluation Approach ..........................................................Error! Bookmark not defined.

6. Data Collection Tools ............................................................Error! Bookmark not defined.

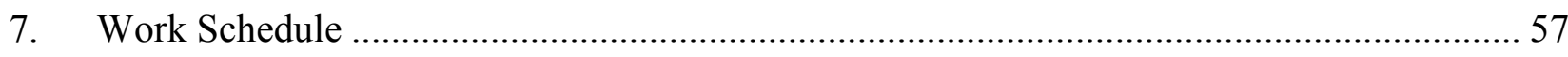




\section{Acronyms}

$\begin{array}{ll}\text { ABA } & \text { Afghanistan Banks Association } \\ \text { ADB } & \text { Asian Development Bank } \\ \text { AIA } & \text { Afghanistan Insurance Authority } \\ \text { AIBF } & \text { Afghanistan Institute of Banking and Finance } \\ \text { AIPA } & \text { Afghanistan Insurance Personnel Association } \\ \text { AMA } & \text { Afghanistan Microfinance Association } \\ \text { AWBF } & \text { Afghanistan Women Business Federation } \\ \text { B2B } & \text { Business to Business } \\ \text { DAB } & \text { Da Afghanistan Bank } \\ \text { DFID } & \text { Department for International Development } \\ \text { DMFIs } & \text { Deposit-taking Microfinance Institutions } \\ \text { EMI } & \text { Electronic Money Institution } \\ \text { FINCA } & \text { Foundation for International Community Assistance } \\ \text { GIRoA } & \text { Government of the Islamic Republic of Afghanistan } \\ \text { IFC } & \text { International Finance Corporation } \\ \text { IIFC } & \text { Islamic Investment and Finance Corporation } \\ \text { KCCI } & \text { Kabul Chamber Of Commerce and Industries } \\ \text { M\&E } & \text { Monitoring and Evaluation } \\ \text { MEU } & \text { Monitoring and Evaluation Unit } \\ \text { MFIs } & \text { Microfinance Institutions } \\ \text { MISFA } & \text { Microfinance Investment Support Facility for Afghanistan } \\ \text { MNOs } & \text { Mobile Network Operators } \\ \text { MoF } & \text { Ministry of Finance } \\ \text { MSMEs } & \text { Micro Small and Medium Enterprises } \\ \text { NGOs } & \text { Non-Government Organizations } \\ \text { OEGI } & \text { Office of Economic Growth and Infrastructure } \\ \text { SMEs } & \text { Small and Medium Enterprises } \\ \text { U.S. } & \text { United States } \\ \text { USAID } & \text { United States Agency for International Development } \\ \text { WB } & \text { World Bank } \\ & \end{array}$




\section{Objectives of the FAIDA Program}

The FAIDA Program's core mission is to create jobs by developing a sustainable, diverse and inclusive financial sector that meets the needs of micro, small and medium enterprises (MSME's) throughout Afghanistan, with a special focus on the agricultural sector and the southern and eastern regions of Afghanistan. In order to meet its objectives and ensure that large numbers of MSMEs have access to a diverse range of financial services FAIDA's Program principal program design employs four (sometimes interlocking) components in providing services and support. The comprehensive approach of the FAIDA Program delivers services to a variety of beneficiaries through components that are identified as:

1. Enterprise (also known as the micro-level);

2. Banking Capacity (also known as the meso-level);

3. Regulatory (also known as the macro-level);

4. Better Than Cash (also known as Mobile Money); and,

5. Gender (cross-cutting through all FAIDA activities).

Through the Enterprise component, the FAIDA Program is designed to work with a variety of beneficiaries at the retail level to ensure that increasing numbers of clients, multiple segments of the population, and a broad geographic sector have improved access to credit and grants. The Enterprise component also assists the private sector in expanding value chains and in expanding the international market for Afghan products.

Through the Banking Capacity component, FAIDA programs are designed to enhance the capacity of financial system services and infrastructure through support of a number of Afghan professional financial institution associations and in providing direct support for financial institutions in building the capacity of their professional staff. Support for Afghan professional banking associations include the Afghanistan Banks Association, the Afghanistan Institute of Banking and Finance, the Afghanistan Microfinance Association and the Afghanistan Insurance Personnel Association.

FAIDA's Regulatory component supports an enabling environment for policy, legal, and regulatory matters (both domestic and international) that enhance transparency and promote financial sector expansion. Due to the current environment, the Regulatory component's contact with Afghanistan's Central Bank has generally been carried out in an in an indirect manner. The Regulatory component has, however, directly or indirectly supported the Enterprise, Banking Capacity and Better Thank Cash components and their beneficiaries in accomplishing significant regulatory objectives.

FAIDA's Better Than Cash component supports Afghanistan's nascent mobile money activities through a combination of technical assistance, grants, innovation programs, and pilot implementation programs. Proposed enabling mobile money legislation has been provided through the assistance of the Regulatory component. The Better Than Cash 
component works closely with GIRoA, Afghanistan's Mobile Network Operators and the Afghanistan Mobile Money Operators Association in expanding the volume of mobile money activities.

FAIDA's Gender component is designed to provide cross-cutting support and involvement in all FAIDA activities. Among its many activities, FAIDA's Gender component coordinates and supports several internship programs such as Women in Business, Women in Government and training in Sharia-compliant financial instruments. FAIDA has also supported pilot training for women in the provinces to become mobile money agents.

\section{Purpose of the Evaluation}

This evaluation is to assess the quality and effectiveness of FAIDA's interventions in the following four areas:

1) MSME jobs created at the micro-level [Enterprise component] as a result of FAIDA's activities;

2) Loans facilitated at the micro-level [Enterprise component] with support of U.S. government assistance through the FAIDA Program, including for female borrowers and underserved MSMEs;

3) FAIDA's technical assistance and grants for sub-award recipients at the meso-level [Banking Capacity Component] to build their institutional and human capacity and advocacy skills. Included in these sub-awardees are: Afghanistan Banks Association, Afghanistan Microfinance Association, Afghanistan Institute of Banking and Finance, and the Afghanistan Insurance Personnel Association (AIPA); and,

4) Regulatory component activities at the macro-level, including policy, legal, and regulatory frameworks, to determine the extent to which the objectives for this component were achieved.

The evaluation will also identify lessons learned and develop specific recommendations to improve project activities. The USAID Office of Economic Growth and Infrastructure (OEGI) intends to use the findings of this evaluation for more focused and target interventions through FAIDA during its last 18-month extension period, and to complement the design of new private sector development activities. The lessons learned will also benefit the larger USAID/Afghanistan mission and other donors working in the financial sector.

\section{Evaluation Questions}

This Final Performance Evaluation will be guided by the following six questions:

1. How effective and efficient have FAIDA's interventions been in creating jobs for men and women in MSME enterprises, financial institutions, and business associations? 
2. How successful has FAIDA's assistance been in enhancing capacity of financial professionals and building advocacy skills for the financial sector beneficiaries (e.g., ABA, AMA, AIBF, and AIPA)?

3. To what extent has FAIDA's interventions integrated women in the financial sector and provided access to finance and opportunities for economic and professional growth?

4. How effective has FAIDA's technical assistance to Afghanistan's mobile network operators been in introducing innovative new products and services and expanding the use of mobile money?

5. What have been FAIDA's key achievements in improving the enabling environment for private-sector-led financial sector development, and how will they impact the sector in the long-run?

6. How successful were FAIDA's matchmaking events in linking financial institutions with MSMEs in need of financing (e.g. business roundtables, innovation fairs, conferences, workshops)?

\section{Evaluation Approach}

The team evaluated FAIDA's activities in the following five geographic locations: Kabul, Kandahar, Herat, Mazar, and Jalalabad. FAIDA's activities have been quite varied over the life of the project and continue to be so at the current time with FAIDA's activities not necessarily homogenous across all five geographic locations identified in the Evaluation SOW. Differing approaches may be required to evaluate FAIDA performance at the Enterprise and Banking Capacity level. Where needed, such as for Mobile Network Operators, specialized questionnaires and interview approaches will be developed.

In each region, the team will meet with both men and women owned MSME's in order to determine whether the program has been successful at improving access to a diverse range of financial services. Generally, the Banking Capacity counterpart organizations are concentrated in Kabul and it is expected that most of the contact with Banking Capacity beneficiaries will occur in the Kabul area. Most of the Regulatory component beneficiaries and activities occur in the Kabul area; however, the evaluation team will attempt to link the satisfaction of the Enterprise, Banking Component and Better than Cash beneficiaries with the FAIDA Regulatory component.

\section{Data Collections Tools}

\section{Document Review}


The evaluation team will have available for analysis a variety of program operational documents and reports provided by the USAID Contracting Officer Representative (COR), including: performance monitoring and evaluation reports; impact assessment and previous evaluation reports; implementation work plans; quarterly and annual implementation progress reports, etc. The desk review will allow the evaluation team to better understand the FAIDA program's goals and objectives, and gain insight into some of the program implementation successes, challenges, and constraints. The team will also be able to determine from the document review if the expected results were met, determine the appropriateness of FAIDA program interventions within the Afghan context, and make appropriate recommendations. Access to FAIDA program design documents will enable the evaluation to distinguish substantive FAIDA program design issues, from the key implementation and/or management capacities, and how arising implementation challenges and processes were managed.

\section{Key Informant Interviews}

This methodology will enable the evaluation team to have a face-to-face interaction with some of the key stakeholders directly and indirectly involved with the FAIDA program, including: the Implementing Partners and project staff; FAIDA senior managers in Kabul and field offices; financial intermediaries; financial sector umbrella and supervisory bodies. While the micro-level beneficiaries will be surveyed by way of a questionnaire and focus group discussions, other key stakeholders will be guided by a series of broad questions tied to the six Evaluation Questions. The evaluators will seek to understand and obtain the views of the key stakeholders and their experience with the FAIDA initiative, and policies and practices with regard to lending to the MSME sector in Afghanistan. The team will also hold consultations with key donor agencies funding the financial sector, or that have similar interventions to FAIDA such as the Department for International Development (DFID) and the Asian Development Bank (ADB), as time allows.

\section{Focus Group Discussions}

This method will be used to obtain information to the six Evaluation Questions from FAIDA micro- and meso-level beneficiaries In the FGD, the evaluation will use a series of broad questions to guide the conversations, but allow for new questions to arise as a result of the discussion. The method will generate focused insights quickly, and complement data and information from the key informants. This tool will help to assess opinions of change, the quality of FAIDA technical support, identify areas of weaknesses and strengths in the credit system, and highlight areas that need improvement.

The FGD will enable the evaluators to better understand:

- How successful the FAIDA intervention has been in creating jobs and sustainability for MSME's in Afghanistan;

- The challenges that the MSME's have experienced in the course of the implementing the credit; and 
- Views on lessons learned and recommendations on how the utilization of FAIDA capacity building resources can be improved to better achieve Program objectives.

\section{Focus Group Break-Out Sessions - Semi-Structured Questionnaire Survey}

Focus groups will include break-out sessions, in which semi-structured survey questionnaires will be administered to participants. Different questionnaires will be administered to different groups of beneficiaries. The questionnaire will cover a range of issues and will be translated into Dari and/or Pashto for ease of understanding and completion by interviewees.

\section{Expert One-on-One Interviews}

Based upon the USAID provided list, the evaluation will consult with financial sector experts at the Da Afghanistan Bank, the Association of Microfinance Institutions (AMFI), the Afghanistan Institute for Banking and Finance (AIBF), the Afghanistan Banks Association (ABA) and similar organizations. The evaluation will learn from their experiences with FAIDA programs any concerns they may have about FAIDA operations, processes, and outcomes; and what they consider to be the strengths and weaknesses of the initiative. Such discussions will establish the implementation performance of the program, constraints faced, and agree on means of overcoming these in future similar interventions.

\section{Beneficiaries Selection}

The USAID provided stakeholders list identifies approximately 54 individuals (many of them very high level individuals) to be contacted. Because of the substantial number of stakeholders identified in the listing, flexibility and selectivity may be required and means and methods of contacting and interviewing these stakeholders. As needed, Checchi Gender Specialists may also be utilized at the meso-level to contact and interview female stakeholders and beneficiaries.

The FAIDA Program continues to provide a wide-array of support and assistance to a variety of individuals, organizations and institutions. Because of the wide-array of FAIDA Program activities, the evaluation team will utilize a mix of qualitative and quantitative data collection and analysis approaches that are appropriate for the beneficiaries being considered and will include:

1. Interviews, as needed, with USAID/Afghanistan's OEGI Staff;

2. Interviews with implementing partner staff in Kabul and its Regional Coordinators;

3. Interviews and/or focus group participation with selected stakeholders based upon the listing provided by USAID Afghanistan;

4. Consultations with other donors (e.g., The World Bank, International Financial Corporation (IFC), the Department for International Development (DFID), the Asian Development Bank (ADB); and, 
5. Focus Group discussions and questionnaires with a sample of beneficiaries in targeted areas to determine perceptions of the MSMEs and financial sector beneficiaries. For the purposes of the evaluation, the FAIDA beneficiaries are defined as:

- MSMEs trainees:

Trainees of Business to Bank Roundtables, Gender Workshops; and, Mobile Money Workshops

- MSMEs supported though loan facilitation

- Financial sector employees trained

- Financial sector professionals/supervisors trained

- Technical assistance recipient financial institutions

- FAIDA grantees:

Businesses;

Professional Associations; and, Mobile Network Operators

6. Interviews, as needed, with USAID/Afghanistan's OEGI Staff;

7. Interviews with implementing partner staff in Kabul and its Regional Coordinators;

8. Interviews and/or focus group participation with selected stakeholders based upon the listing provided by USAID Afghanistan;

9. Consultations with other donors (e.g., The World Bank, International Financial Corporation (IFC), the Department for International Development (DFID), the Asian Development Bank (ADB); and,

10. Focus Group discussions and questionnaires with a sample of beneficiaries in targeted areas to determine perceptions of the MSMEs and financial sector beneficiaries. For the purposes of the evaluation, the FAIDA beneficiaries are defined as:

- MSMEs trainees:

1. Trainees of Business to Bank Roundtables,

2. Gender Workshops; and,

3. Mobile Money Workshops

- MSMEs supported though loan facilitation

- Financial sector employees trained

- Financial sector professionals/supervisors trained

- Technical assistance recipient financial institutions

- FAIDA grantees:

1. Businesses;

2. Professional Associations; and,

3. Mobile Network Operators

The evaluation approach will examine outcomes for both women and men at the Enterprise, Banking Capacity, Regulatory and Better Than Cash Components to ensure that the project achieved the best results for all targeted beneficiaries and stakeholders. All data collected and presented in the evaluation report will be disaggregated by sex and geography. Lessons learned, quality of impact, and level of sustainability will be addressed by these variables. 
Analysis of successes or failures will be compared and contrasted by province as some interventions may be successful in some provinces, but not in others. The evaluation design and methodology will be designed to provide actionable guidance to USAID for current and future programming.

\section{Work Schedule}

\begin{tabular}{|c|c|c|}
\hline Activities & Beginning Dates & \begin{tabular}{l}
\multicolumn{2}{c}{ Duratio } \\
$\mathrm{n}$ in \\
Days
\end{tabular} \\
\hline Travel to and from Afghanistan & 23-APR-2015 & 2 \\
\hline In-briefing with USAID & 27-APR-2015 & 1 \\
\hline Draft work plan & 25-APR-2015 & 5 \\
\hline \multicolumn{3}{|l|}{$\begin{array}{l}\text { Field } \\
\text { Work: }\end{array}$} \\
\hline Interviews with FAIDA management in Kabul & 29-APR-2015 & 2 \\
\hline Interviews with selected stakeholders in Kabul & 02-MAY-2015 & 2 \\
\hline Consultation with other Donors & 04-APR-2015 & 1 \\
\hline Interviews with GIRoA Umbrella Organizations & 05-MAY-2015 & 2 \\
\hline Interviews with Trade Umbrella Organizations & 07-MAY-2015 & 2 \\
\hline \multicolumn{3}{|l|}{$\begin{array}{l}\text { Focus Group discussions and questionnaires with a } \\
\text { sample of beneficiaries in targeted areas: }\end{array}$} \\
\hline Kabul & 04-MAY-2015 & 3 \\
\hline Revision of questionnaires, as needed & 07-MAY-2015 & 2 \\
\hline Jalalabad & 10-MAY-2015 & 4 \\
\hline Mazar & 10-MAY-2015 & 4 \\
\hline Analysis and revisions (as needed) - in Kabul & 14-MAY-2015 & 4 \\
\hline Kandahar & 17-MAY-2015 & 4 \\
\hline Herat & 17-MAY-2015 & 4 \\
\hline Analysis of Focus Group questionnaires & 21-MAY-2015 & 3 \\
\hline Secondary Data Analysis & 23-MAY-2015 & 5 \\
\hline Mid-point briefing & 26-MAY-2015 & 1 \\
\hline Data analysis, preliminary report and presentation to USAID & 29-MAY-2015 & 6 \\
\hline Begin drafting final report & 04-JUNE-2015 & 2 \\
\hline Out-briefing with USAID & 07-JUNE-2015 & 1 \\
\hline Travel out of Kabul & 08-JUNE-2015 & 2 \\
\hline Draft Final report & Out of Country & 3 \\
\hline Finalize Report & Out of Country & 3 \\
\hline
\end{tabular}




\section{BibliogRAPHY OF DOCUMENTS REVIEWED}

1. FAIDA Project Modifications

2. FAIDA Annual Work Plans

3. Performance Monitoring Plan (PMP) or M\&E Plan

4. Data Quality Assessments

5. Government Collaboration or coordination documents

6. FAIDA Reports (Annual, Quarterly, Monthly, Biweekly, Weekly)

7. Audit Report Num. F-306-14-002-

8. FAIDA M\&E Field Verification Reports

9. Gender Analysis

10. AIBF Assessment Report Final Draft July 282011

11. AMA Draft Institutional Assessment Report

12. ABA Strategic Plan

13. MISFA Strategic Plan 2013-2015

14. FAIDA Trackers 


\section{Schedule of Meetings}

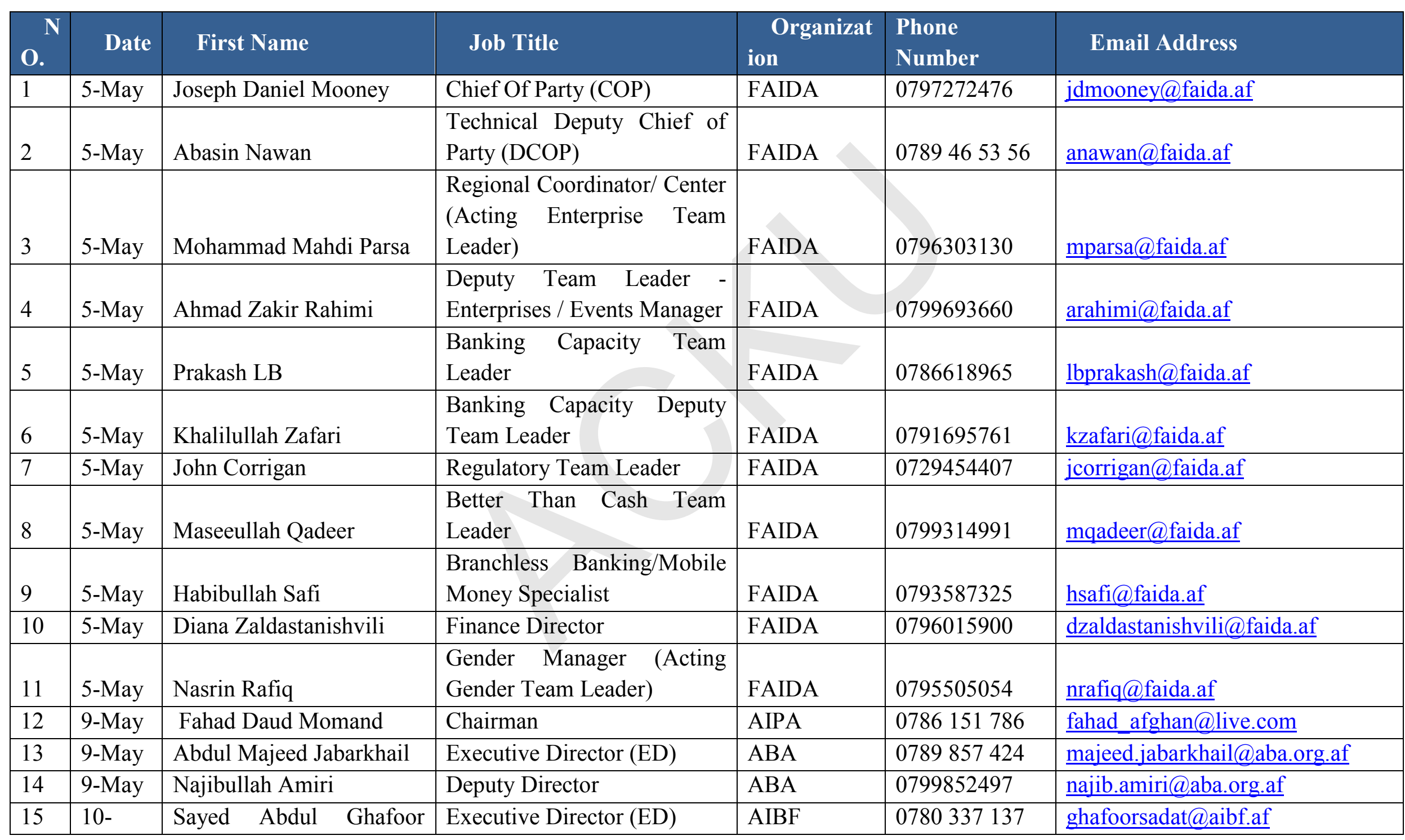




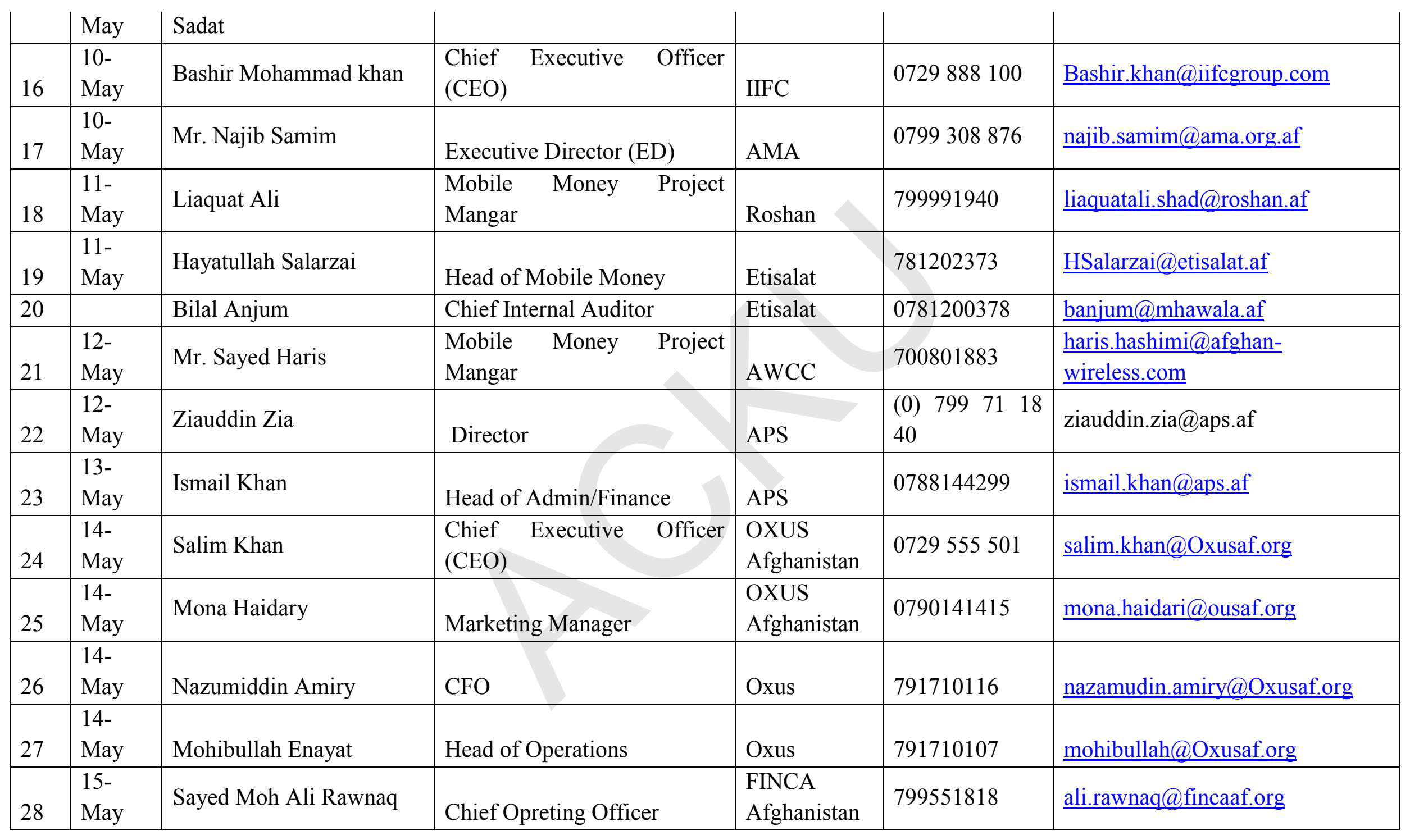




\begin{tabular}{|c|c|c|c|c|c|c|}
\hline 29 & $\begin{array}{l}\text { 16- } \\
\text { May }\end{array}$ & Bahram Barzin & Managing Director & $\begin{array}{l}\text { Microfinance } \\
\text { Investment } \\
\text { Support } \\
\text { Facility for } \\
\text { Afghanistan } \\
\text { (MISFA) }\end{array}$ & 0729555550 & bahram.barzin@misfa.org.af \\
\hline 30 & $\begin{array}{l}17- \\
\text { May }\end{array}$ & Meagan & Senior Marketing Officer & IFC & 701133398 & mandrew1@ifc.org \\
\hline
\end{tabular}

\section{List of End Borrowers Meetings}

\begin{tabular}{|c|c|c|c|c|c|c|c|c|c|}
\hline O. & Date & Type & Gender & Name & Job Title & Organizatio & Province & $\begin{array}{l}\text { Phone } \\
\text { Number }\end{array}$ & Email Address \\
\hline 1 & 14-May & MatchMaking & Male & Ahmed Javed & $\begin{array}{l}\text { Contract } \\
\text { Manager }\end{array}$ & $\begin{array}{l}\text { Seerat } \\
\text { Education } \\
\text { Center }\end{array}$ & Kabul & $\begin{array}{l}078800222 \\
2\end{array}$ & $\begin{array}{l}\text { ahmadjaved@acs- } \\
\underline{\text { af.com }}\end{array}$ \\
\hline 2 & 14-May & MatchMaking & Male & Babrak & $\begin{array}{l}\text { Program } \\
\text { Advisor }\end{array}$ & $\begin{array}{l}\text { Seerat } \\
\text { Education } \\
\text { Center }\end{array}$ & Kabul & $\begin{array}{l}070819843 \\
7\end{array}$ & $\frac{\text { babrak.khurasani }}{\underline{\text { ayahoo.com }}}$ \\
\hline 3 & 14-May & MatchMaking & Female & Najiba Muram & Director & Muram Radio & Kabul & $\begin{array}{l}070024184 \\
5\end{array}$ & $\begin{array}{l}\text { najibamuram@yah } \\
\underline{\text { oo.com }}\end{array}$ \\
\hline 4 & 14-May & MatchMaking & Female & Rahila Sajadi & Director & SVOWCW & Kabul & 079966498 & $\begin{array}{l}\text { rahela.sajadi@yah } \\
\underline{\text { oo.com }}\end{array}$ \\
\hline 5 & 14-May & MatchMaking & Female & Saleha Ahmadzai & Director & ASR Company & Kabul & 782382821 & $\begin{array}{l}\text { salehaahmadzai@ } \\
\text { yahoo.com }\end{array}$ \\
\hline 6 & 14-May & MatchMaking & Female & Maria & Director & Seerat & Kabul & 070029099 & seerat2005@yaho \\
\hline
\end{tabular}




\begin{tabular}{|c|c|c|c|c|c|c|c|c|c|}
\hline & & & & & & $\begin{array}{l}\text { Education } \\
\text { Center }\end{array}$ & & 1 & $\underline{\text { o.com }}$ \\
\hline 7 & 15-May & Gender & Male & $\begin{array}{l}\text { Said Mohammad } \\
\text { Isa }\end{array}$ & Director & $\begin{array}{l}\text { Abu Raihan } \\
\text { Compan }\end{array}$ & Kabul & $\begin{array}{l}079932879 \\
9\end{array}$ & $\begin{array}{l}\text { saidessa.fazeli@g } \\
\text { mail.com }\end{array}$ \\
\hline 8 & 15-May & Gender & Female & Hanifa Fatemi & Director & $\begin{array}{l}\text { Shareen } \\
\text { Qaharaman ltd }\end{array}$ & Kabul & $\begin{array}{l}079935074 \\
3\end{array}$ & $\begin{array}{l}\text { anifa.fatmi@yaho } \\
\text { o.com }\end{array}$ \\
\hline 9 & 15-May & Gender & Female & Minaa Khashe & Director & $\begin{array}{l}\text { Khod Kefa } \\
\text { Handicraft }\end{array}$ & Kabul & $\begin{array}{l}070019701 \\
1\end{array}$ & \\
\hline 10 & 15-May & Gender & Female & Madina Safari & $\begin{array}{l}\text { Genral } \\
\text { Manager }\end{array}$ & $\begin{array}{l}\text { Kabul Green } \\
\text { Handicraft }\end{array}$ & Kabul & 794611300 & $\begin{array}{l}\text { madina.safary@g } \\
\text { mail.com }\end{array}$ \\
\hline 11 & 15-May & Gender & Male & Taqi Husini & Deputy & $\begin{array}{l}\text { Shahan Agri } \\
\text { Production }\end{array}$ & Kabul & 779756152 & \\
\hline 12 & 15-May & Gender & Male & $\begin{array}{ll}\text { Moh } & \text { Ibrahim } \\
\text { Sarwari } & \\
\end{array}$ & Director & $\begin{array}{l}\text { Shahan Agri } \\
\text { Production }\end{array}$ & Kabul & 797900079 & $\begin{array}{l}\text { ab.sarwari90006@ } \\
\text { gmail.com }\end{array}$ \\
\hline 13 & 15-May & Gender & Male & Said Latif Sajadi & Manager & $\begin{array}{l}\text { Burg Bahar } \\
\text { Prodcution } \\
\text { Company }\end{array}$ & Kabul & 797898828 & $\begin{array}{l}\text { latifsajadi@yahoo. } \\
\underline{\text { com }}\end{array}$ \\
\hline 14 & 15-May & Gender & Female & Rihana Husini & Director & $\begin{array}{l}\text { Burg Bahar } \\
\text { Prodcution } \\
\text { Company }\end{array}$ & Kabul & 794886544 & $\begin{array}{l}\text { r.hussaini2013@y } \\
\underline{\text { ahoo.com }}\end{array}$ \\
\hline 15 & 16-May & Mobile Money & Male & Abdullah & $\begin{array}{l}\text { Marketing } \\
\text { Manager }\end{array}$ & $\begin{array}{ll}\text { BK } & \text { Group } \\
\text { Media } & \\
\end{array}$ & Kabul & 783107882 & - \\
\hline 16 & 16-May & Mobile Money & Male & Murtaza & $\begin{array}{l}\text { Marketing } \\
\text { Manager }\end{array}$ & $\begin{array}{l}\text { Export } \\
\text { Company }\end{array}$ & Kabul & 781310031 & - \\
\hline 17 & 16-May & Mobile Money & Male & Habib & Student & $\begin{array}{l}\text { Livestock } \\
\text { Clinic }\end{array}$ & Kabul & 772978510 & - \\
\hline 18 & 16-May & Mobile Money & Male & $\begin{array}{ll}\text { Ayad } & \text { Ahmad } \\
\text { Ahmadi } & \end{array}$ & Shopkeeper & Ag Depo & Kabul & 700662896 & \\
\hline
\end{tabular}




\begin{tabular}{|c|c|c|c|c|c|c|c|c|c|}
\hline 19 & 16-May & Mobile Money & Male & Ramadan & Paravet & Ag Depo & Kabul & 779742069 & \\
\hline 20 & 16-May & Mobile Money & Male & Abdul Hadi & Shopkeeper & Ag Depo & Kabul & 775127574 & \\
\hline 21 & 16-May & End Borrowers & Male & Rohullah & Salesman & $\begin{array}{l}\text { Azizi Akbari } \\
\text { Brothers Ltd }\end{array}$ & Kabul & 778900900 & $\begin{array}{l}\text { roohullah_safi@ya } \\
\text { hoo.com }\end{array}$ \\
\hline 22 & 16-May & End Borrowers & Male & Bakhtiyar Haidari & Director & $\begin{array}{l}\text { Kabul Moan } \\
\text { Electonics }\end{array}$ & Kabul & 799528693 & $\begin{array}{l}\text { Kabul_moan@yah } \\
\text { oo.com }\end{array}$ \\
\hline 23 & 28-May & End Borrowers & Female & Surya & Tailor & Tailoring & Kabul & 744154871 & \\
\hline 24 & 28-May & End Borrowers & Female & Humaira & Director & $\begin{array}{l}\text { Humaira } \\
\text { Handicrafts }\end{array}$ & Kabul & 781681274 & \\
\hline 25 & 28-May & End Borrowers & Female & Mahboba & Tailor & Tailoring & Kabul & 799516186 & \\
\hline 26 & 28-May & End Borrowers & Female & Fozia & Tailor & Tailoring & Kabul & 780642784 & \\
\hline 27 & 29-May & End Borrowers & Female & Shahar Bano & Beauty Polar & Beauty Polar & Kabul & 799017906 & \\
\hline 28 & 29-May & End Borrowers & Female & Nafisa & Tailor & Tailoring & Kabul & 799370639 & \\
\hline 29 & 18-May & Mobile Money & Male & $\begin{array}{ll}\text { Mehar } & \text { Dil } \\
\text { Mandozai } & \\
\end{array}$ & Director & $\begin{array}{l}\text { Arghawan } \\
\text { Nursury Farm }\end{array}$ & Balkh & 793258575 & \\
\hline 30 & 18-May & Mobile Money & Female & Rabia Maryam & Director & Rabia Maryam & Balkh & 794383572 & \\
\hline 31 & 18-May & Mobile Money & Male & Hafizull & Paravet & Paravat NHLP & Balkh & 792338657 & \\
\hline 32 & 18-May & End Borrowers & Male & Moh Rasul & Manager & $\begin{array}{ll}\text { Nazami Aiwa } \\
\text { Plastic }\end{array}$ & Balkh & & \\
\hline 33 & 18-May & End Borrowers & Female & Shokria & Manager & $\begin{array}{l}\text { Danish } \\
\text { Association }\end{array}$ & Balkh & 799430300 & $\begin{array}{l}\text { shokria.asadi@gm } \\
\text { ail.com }\end{array}$ \\
\hline 34 & 18-May & End Borrowers & Female & Bibi Gul & Director & $\begin{array}{l}\text { Pairozi } \\
\text { Association }\end{array}$ & Balkh & 793588124 & \\
\hline 35 & 18-May & End Borrowers & Female & Horia & Manager & $\begin{array}{l}\text { Zarin Tailoring } \\
\text { Shop }\end{array}$ & Balkh & 789912714 & \\
\hline 36 & 18-May & End Borrowers & Female & Nafisa & Manager & Sadaf Store & Balkh & 797187329 & \\
\hline
\end{tabular}




\begin{tabular}{|c|c|c|c|c|c|c|c|c|}
\hline 37 & 18-May & End Borrowers & Male & Hassan Ali & Shopkeeper & Dry Fruit Store & Balkh & 798098060 \\
\hline 38 & 18-May & End Borrowers & Male & Javed & $\begin{array}{l}\text { Marketing } \\
\text { Manager }\end{array}$ & Taibzada Ltd & Balkh & 790292222 \\
\hline 39 & 18-May & End Borrowers & Male & Moh Yaseen & $\begin{array}{l}\text { Finance } \\
\text { Manager }\end{array}$ & Taibzada Ltd & Balkh & 795152434 \\
\hline 40 & 18-May & End Borrowers & Male & Moh Yousef & Deputy & $\begin{array}{l}\text { Shefa } \\
\text { Prodction } \\
\text { Company }\end{array}$ & Balkh & 798986986 \\
\hline 41 & 19-May & Gender & Female & Waheeda & Deputy & $\begin{array}{l}\text { Khadija } \\
\text { Kobara } \\
\text { Association }\end{array}$ & Balkh & 791413179 \\
\hline 42 & 19-May & Gender & Male & Bahadur & Member & $\begin{array}{l}\text { Khadija } \\
\text { Kobara } \\
\text { Association }\end{array}$ & Balkh & 794510267 \\
\hline 43 & 19-May & Gender & Female & Neela & Manager & Beauty Polar & Balkh & 774564585 \\
\hline 44 & 19-May & Gender & Female & Nigaina & Worker & $\begin{array}{l}\text { Omed } \\
\text { Handicraft }\end{array}$ & Balkh & - \\
\hline 45 & 19-May & Gender & Female & Karima & Manager & $\begin{array}{l}\text { Omed } \\
\text { Handicraft }\end{array}$ & Balkh & 700514471 \\
\hline 46 & 19-May & Gender & Female & Engeela & Manager & $\begin{array}{l}\text { Faryab } \\
\text { Livestock } \\
\text { Farm }\end{array}$ & Balkh & 766225701 \\
\hline 47 & 19-May & Gender & Female & Kokaba & Member & $\begin{array}{l}\text { Blakh Women } \\
\text { Agri Company }\end{array}$ & Balkh & 700522720 \\
\hline 48 & 19-May & Gender & Female & Atifa & Manager & $\begin{array}{l}\text { Durokhshan } \\
\text { Production } \\
\text { Company }\end{array}$ & Balkh & 775131221 \\
\hline
\end{tabular}




\begin{tabular}{|c|c|c|c|c|c|c|c|c|c|}
\hline 49 & 20-May & MatchMaking & Female & Shahnaaz & Member & $\begin{array}{l}\text { Durokhshan } \\
\text { Cooprative }\end{array}$ & Balkh & 797099631 & \\
\hline 50 & 20-May & MatchMaking & Male & Said Mustafa & Deputy & $\begin{array}{l}\text { Anwar } \\
\text { Mustafa Ltd }\end{array}$ & Balkh & 771066006 & \\
\hline 51 & 20-May & MatchMaking & Male & Fazaludin Ansari & Manager & $\begin{array}{l}\text { Department of } \\
\text { Economy }\end{array}$ & Balkh & 700536342 & \\
\hline 52 & 20-May & MatchMaking & Female & Muzhgan & Manager & Azizi Film & Balkh & 729999161 & \\
\hline 53 & 20-May & MatchMaking & Female & Masoma & HandiCraft & $\begin{array}{l}\text { Aser Naween } \\
\text { Association }\end{array}$ & Balkh & 773463132 & \\
\hline 54 & 20-May & MatchMaking & Female & Fahima Rahimi & HandiCraft & $\begin{array}{l}\text { Balkh } \\
\text { Businesswome } \\
\text { n Association }\end{array}$ & Balkh & 774415892 & \\
\hline 55 & 20-May & MatchMaking & Male & $\begin{array}{l}\text { Abdul Raqib } \\
\text { Jahid }\end{array}$ & Manager & $\begin{array}{l}\text { Purana } \\
\text { Marketing } \\
\text { Company }\end{array}$ & Balkh & 700579245 & \\
\hline 56 & 20-May & MatchMaking & Male & Ahmad Farzad & Member & $\begin{array}{l}\text { Balkh Youth } \\
\text { Association }\end{array}$ & Balkh & 790114278 & \\
\hline 57 & 20-May & MatchMaking & Male & Mohammad Azim & $\begin{array}{l}\text { Finance } \\
\text { Manager }\end{array}$ & $\begin{array}{l}\text { Ghazanfar } \\
\text { Group }\end{array}$ & Balkh & 700529971 & \\
\hline 58 & 20-May & MatchMaking & Female & Habiba & Director & $\begin{array}{l}\text { Khawar } \\
\text { Association }\end{array}$ & Balkh & 779085497 & \\
\hline 59 & 20-May & MatchMaking & Female & Rahima & Director & $\begin{array}{l}\text { Shirabad } \\
\text { Cooprative }\end{array}$ & Balkh & 796187671 & \\
\hline 60 & 24-May & End Borrowers & Female & Hiada Gulzar & $\begin{array}{l}\text { Marketing } \\
\text { Manager }\end{array}$ & Black Rose & Herat & 790877724 & $\begin{array}{l}\text { haydah.gulzar@g } \\
\underline{\text { mail.com }}\end{array}$ \\
\hline 61 & 24-May & End Borrowers & Female & Reka Saadat & Director & $\begin{array}{l}\text { Abnos Women } \\
\text { Production }\end{array}$ & Herat & 798636034 & $\begin{array}{l}\text { rekafahim@yahoo. } \\
\text { com }\end{array}$ \\
\hline
\end{tabular}




\begin{tabular}{|c|c|c|c|c|c|c|c|c|c|}
\hline & & & & & & Group & & & \\
\hline 62 & 24-May & End Borrowers & Male & Reza Waizi & Teacher & $\begin{array}{l}\text { Mahek } \\
\text { Training } \\
\text { Center }\end{array}$ & Herat & 783675867 & $\underline{\text { rezaraezi779@gm }}$ \\
\hline 63 & 24-May & End Borrowers & Male & Haji Mohammad & Director & Farah Goster & Herat & 799354314 & \\
\hline 64 & 24-May & End Borrowers & Male & $\begin{array}{l}\text { Ghulam } \quad \text { Yahya } \\
\text { Ahmadi }\end{array}$ & Manager & $\begin{array}{l}\text { Sahel stone } \\
\text { company }\end{array}$ & Herat & 799185000 & $\begin{array}{l}\text { jahansangsahel@g } \\
\text { mail.com }\end{array}$ \\
\hline 65 & 24-May & End Borrowers & Male & Abdul Ahad & $\begin{array}{l}\text { Finance } \\
\text { Manager }\end{array}$ & $\begin{array}{l}\text { Nigin Brothers } \\
\text { Company }\end{array}$ & Herat & 799164210 & \\
\hline 66 & 24-May & End Borrowers & Male & Masoor Rahimi & Manager & MKS & Herat & 793111916 & $\begin{array}{l}\text { mansour.rahimi@ } \\
\text { mks.com.tr }\end{array}$ \\
\hline 67 & 24-May & End Borrowers & Female & Saweeta Durani & Director & $\begin{array}{l}\text { Herewa } \\
\text { Business } \\
\text { Company }\end{array}$ & Herat & 799065389 & $\begin{array}{l}\text { sweeta.durani@g } \\
\text { mail.com }\end{array}$ \\
\hline 68 & 24-May & End Borrowers & Female & Saeeda Hosini & Student & Handicraft & Herat & 789694820 & \\
\hline 69 & 24-May & End Borrowers & Female & $\begin{array}{l}\text { Zainab } \\
\text { Khudadadi }\end{array}$ & Teacher & Handicraft & Herat & 783467899 & \\
\hline 70 & 24-May & End Borrowers & Male & $\begin{array}{l}\text { Said Akbar } \\
\text { Hashimi }\end{array}$ & Director & $\begin{array}{l}\text { Training } \\
\text { Center }\end{array}$ & Herat & 780087210 & \\
\hline 71 & 24-May & End Borrowers & Male & $\begin{array}{l}\text { Mubarak Shah } \\
\text { Alowi }\end{array}$ & Manager & $\begin{array}{l}\text { Training } \\
\text { Center }\end{array}$ & Herat & 787441300 & \\
\hline 72 & 24-May & End Borrowers & Male & Mosen & Manager & Tanin & Herat & 729294422 & \\
\hline 73 & 24-May & End Borrowers & Female & Shakila & Manager & Bahar Café & Herat & 790665194 & \\
\hline 74 & 25-May & Gender & Female & Masoma & Director & $\begin{array}{l}\text { Zana Jan } \\
\text { Women Shura }\end{array}$ & Herat & 776552267 & \\
\hline 75 & 25-May & Gender & Female & Hajera & Member & Kojaha Shura & Herat & 779703042 & \\
\hline 76 & 25-May & Gender & Female & Nafisa & Deputy & Bee $\quad$ Keeper & Herat & 790434061 & \\
\hline
\end{tabular}




\begin{tabular}{|c|c|c|c|c|c|c|c|c|c|}
\hline & & & & & & Assosiation & & & \\
\hline 77 & 25-May & Gender & Female & Seemain & Member & $\begin{array}{l}\text { Bee Keeper } \\
\text { Assosiation }\end{array}$ & Herat & & \\
\hline 78 & 25-May & Gender & Female & Sara & Member & $\begin{array}{l}\text { Dairy } \\
\text { Processing }\end{array}$ & Herat & 790735989 & \\
\hline 79 & 25-May & Gender & Female & Huma & Member & $\begin{array}{l}\text { Sofferon } \\
\text { Assosiation }\end{array}$ & Herat & & \\
\hline 80 & 25-May & Gender & Female & Marya & Member & $\begin{array}{l}\text { Sofferon } \\
\text { Assosiation }\end{array}$ & Herat & & \\
\hline 81 & 25-May & Gender & Female & Arifa & Member & Cooprative & Herat & 772424831 & \\
\hline 82 & 25-May & Gender & Female & Mujhda & Member & Cooprative & Herat & & \\
\hline 83 & 25-May & Gender & Female & Zarmina & Member & MoLSA & Herat & 799547790 & \\
\hline 84 & 25-May & Gender & Female & Sosan & Member & $\begin{array}{l}\text { Saba Sister } \\
\text { Company }\end{array}$ & Herat & 796745545 & \\
\hline 85 & 25-May & Gender & Female & Sorya & Member & $\begin{array}{l}\text { Arman Saba } \\
\text { Company }\end{array}$ & Herat & 797797458 & \\
\hline 86 & 26-May & MatchMaking & Male & Jalil Ahmad & 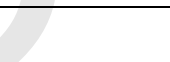 & Baba Sofferon & Herat & 799431105 & \\
\hline 87 & 26-May & MatchMaking & Male & Moh Rafi & & Afgha Left & Herat & 798282512 & \\
\hline 88 & 26-May & MatchMaking & Male & Moh Taqi & & $\begin{array}{l}\text { Education } \\
\text { Center }\end{array}$ & Herat & 791480408 & \\
\hline 89 & 26-May & MatchMaking & Female & Siddiqa Temaski & & $\begin{array}{l}\text { Duna Silk } \\
\text { Production } \\
\text { Company }\end{array}$ & Herat & 799242459 & \\
\hline 90 & 26-May & MatchMaking & Female & Elaha Frotan & & $\begin{array}{l}\text { Hami Numa } \\
\text { Marketing } \\
\text { Company }\end{array}$ & Herat & 799307190 & \\
\hline 91 & 26-May & MatchMaking & Male & Mairwas Ahmadi & & Gozara & Herat & 795817281 & \\
\hline
\end{tabular}




\begin{tabular}{|c|c|c|c|c|c|c|c|c|}
\hline & & & & & & $\begin{array}{l}\text { Women } \\
\text { Assosiation }\end{array}$ & & \\
\hline 92 & 26-May & MatchMaking & Male & Gulam Faroq & & $\begin{array}{ll}\text { Abdul } & \text { Haq } \\
\text { Logistic } & \\
\text { Services } & \end{array}$ & Herat & \\
\hline 93 & 26-May & MatchMaking & Male & Rozhan Tajik & & $\begin{array}{l}\text { Hami Numa } \\
\text { Marketing } \\
\text { Company }\end{array}$ & Herat & 790693505 \\
\hline 94 & 26-May & MatchMaking & Female & Saleha Faizan & & $\begin{array}{l}\text { Sharifi Car } \\
\text { Seller }\end{array}$ & Herat & 790969380 \\
\hline 95 & 26-May & MatchMaking & Male & Moh Rasol Faiq & & $\begin{array}{l}\text { Carpet } \\
\text { Production and } \\
\text { Exporters } \\
\text { Assosiation }\end{array}$ & Herat & 799363714 \\
\hline 96 & 26-May & MatchMaking & Male & Farhad & & $\begin{array}{l}\text { Asayes Group } \\
\text { of Companies }\end{array}$ & Herat & 790472916 \\
\hline 97 & 26-May & MatchMaking & Female & Sorya Ishaqzai & & $\begin{array}{l}\text { Saba Expert } \\
\text { Company }\end{array}$ & Herat & 797797458 \\
\hline 98 & 26-May & MatchMaking & Female & Seema Ahmadi & & $\begin{array}{l}\text { Bano Food } \\
\text { Processing } \\
\text { Company }\end{array}$ & Herat & 792772268 \\
\hline 99 & 26-May & MatchMaking & Female & Sosan Karimi & & $\begin{array}{l}\text { Saba Sister } \\
\text { Company }\end{array}$ & Herat & 729776049 \\
\hline $\begin{array}{l}10 \\
0\end{array}$ & 26-May & MatchMaking & Female & Sameea & & $\begin{array}{l}\text { Saba Sister } \\
\text { Company }\end{array}$ & Herat & 700420520 \\
\hline $\begin{array}{l}10 \\
1\end{array}$ & 26-May & MatchMaking & Male & Moh Arif Ahmadi & Duputy & Afghan Final & Herat & 787679736 \\
\hline
\end{tabular}




\begin{tabular}{|c|c|c|c|c|c|c|c|c|}
\hline $\begin{array}{l}10 \\
2\end{array}$ & 22-May & Gender & Female & Sara & & & Kandahar & 700363713 \\
\hline $\begin{array}{l}10 \\
3\end{array}$ & 22-May & Gender & Female & Suraya & & & Kandahar & \\
\hline $\begin{array}{l}10 \\
4\end{array}$ & 22-May & Gender & Female & Nilofar & & & Kandahar & 786910349 \\
\hline $\begin{array}{l}10 \\
5\end{array}$ & 22-May & MatchMaking & Male & Rohullah & Director & $\begin{array}{ll}\text { ARB } & \text { Steel } \\
\text { Mill } & \\
\end{array}$ & Kandahar & 700338826 \\
\hline $\begin{array}{l}10 \\
6\end{array}$ & 22-May & MatchMaking & Male & Aziz Ahmadyar & & AG Marbles & Kandahar & 700307021 \\
\hline $\begin{array}{l}10 \\
7\end{array}$ & 22-May & MatchMaking & Male & Haji Baridad & & & Kandahar & 700322552 \\
\hline $\begin{array}{l}10 \\
8\end{array}$ & 22-May & MatchMaking & Male & Ahmad & & $\begin{array}{l}\text { Muradi Baba } \\
\text { Ltd. }\end{array}$ & Kandahar & 700311713 \\
\hline $\begin{array}{l}10 \\
9\end{array}$ & 22-May & MatchMaking & Male & Abdul Bari & & & Kandahar & 700300347 \\
\hline $\begin{array}{l}11 \\
0\end{array}$ & 22-May & MatchMaking & Male & Azizi & & & Kandahar & 700300810 \\
\hline $\begin{array}{l}11 \\
1\end{array}$ & 22-May & MatchMaking & Male & Farid Ahmad & & $\begin{array}{l}\text { Zamin Plastic } \\
\text { Industry }\end{array}$ & Kandahar & 700271174 \\
\hline $\begin{array}{l}11 \\
2 \\
\end{array}$ & 22-May & MatchMaking & Male & Fawad Ahmad & & & Kandahar & 799499170 \\
\hline $\begin{array}{l}11 \\
3\end{array}$ & 22-May & MatchMaking & Male & $\begin{array}{l}\text { Mohammad } \\
\text { Hanif }\end{array}$ & & & Kandahar & 703050375 \\
\hline $\begin{array}{l}11 \\
4\end{array}$ & 21-May & End Borrowers & Male & Abdul Razaq & & & Kandahar & \\
\hline $\begin{array}{l}11 \\
5\end{array}$ & 21-May & End Borrowers & Male & Abdul Rashid & & & Kandahar & \\
\hline
\end{tabular}




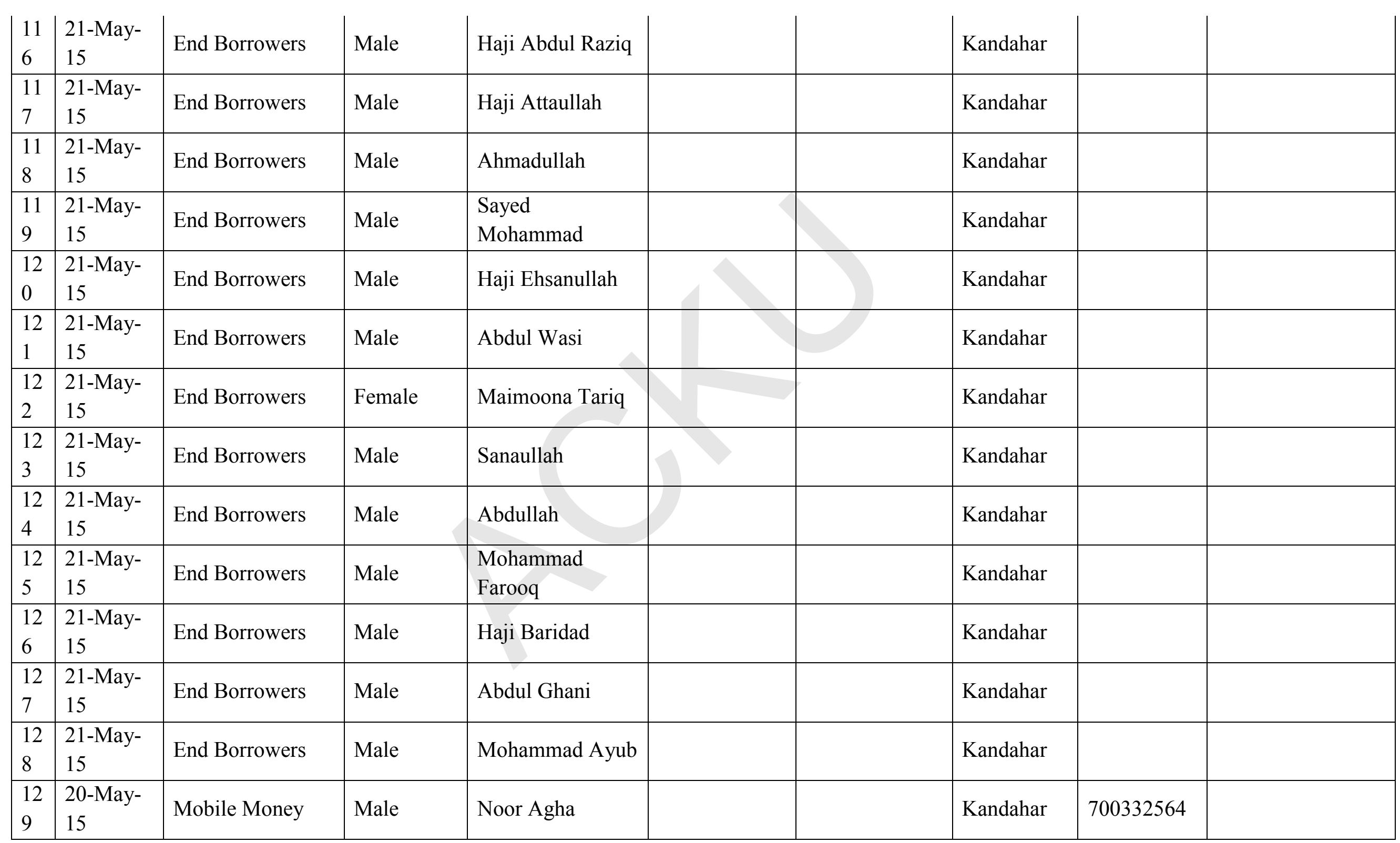




\begin{tabular}{|c|c|c|c|c|c|c|c|c|}
\hline $\begin{array}{l}13 \\
0\end{array}$ & $\begin{array}{l}\text { 20-May- } \\
15\end{array}$ & Mobile Money & Male & Sayed Noor Shah & & & Kandahar & 700302090 \\
\hline $\begin{array}{l}13 \\
1\end{array}$ & $\begin{array}{l}\text { 20-May- } \\
15\end{array}$ & Mobile Money & Male & Mazullah & & & Kandahar & 700304736 \\
\hline $\begin{array}{l}13 \\
2\end{array}$ & $\begin{array}{l}\text { 20-May- } \\
15\end{array}$ & Mobile Money & Male & Mehdi Agha & & & Kandahar & 700350936 \\
\hline $\begin{array}{l}13 \\
3\end{array}$ & $\begin{array}{l}\text { 20-May- } \\
15\end{array}$ & Mobile Money & Male & Eng. Baryalai & & & Kandahar & 700318427 \\
\hline $\begin{array}{l}13 \\
4\end{array}$ & $\begin{array}{l}\text { 20-May- } \\
15\end{array}$ & Mobile Money & Male & Khairullah & & & Kandahar & 703556240 \\
\hline $\begin{array}{l}13 \\
5\end{array}$ & $\begin{array}{l}\text { 20-May- } \\
15\end{array}$ & Mobile Money & Male & Mazullah & & & Kandahar & 700316412 \\
\hline $\begin{array}{l}13 \\
6\end{array}$ & $\begin{array}{l}\text { 18-May- } \\
15\end{array}$ & Gender & Male & Usman Safi & $\begin{array}{l}\text { Deputy } \\
\text { Director }\end{array}$ & AWAA & Nangarhar & 700632963 \\
\hline $\begin{array}{l}13 \\
7\end{array}$ & $\begin{array}{l}\text { 18-May- } \\
15\end{array}$ & Gender & Female & Maiwa Khan & Officer & Raz Handicraft & Nangarhar & 777078460 \\
\hline $\begin{array}{l}13 \\
8\end{array}$ & $\begin{array}{l}\text { 18-May- } \\
15\end{array}$ & Gender & Female & Adina Barkzai & & NAHVC & Nangarhar & 788724965 \\
\hline $\begin{array}{l}13 \\
9 \\
\end{array}$ & $\begin{array}{l}\text { 18-May- } \\
15\end{array}$ & Gender & Female & Sharifa & M\&E Officer & ORSTW & Nangarhar & 784287140 \\
\hline $\begin{array}{l}14 \\
0\end{array}$ & $\begin{array}{l}\text { 18-May- } \\
15\end{array}$ & Gender & Female & Muniroza & $\begin{array}{l}\text { Vocational } \\
\text { Manager }\end{array}$ & & Nangarhar & 799343037 \\
\hline $\begin{array}{l}14 \\
1\end{array}$ & $\begin{array}{l}\text { 18-May- } \\
15\end{array}$ & Gender & Male & Sharif & Director & Ali Sahil & Nangarhar & 79679002 \\
\hline $\begin{array}{l}14 \\
2\end{array}$ & $\begin{array}{l}\text { 18-May- } \\
15\end{array}$ & Gender & Female & Nadia & & & Nangarhar & 784582310 \\
\hline $\begin{array}{l}14 \\
3\end{array}$ & $\begin{array}{l}\text { 18-May- } \\
15\end{array}$ & MatchMaking & Female & Gul Ghotai & & & Nangarhar & 781690411 \\
\hline
\end{tabular}




\begin{tabular}{|c|c|c|c|c|c|c|c|}
\hline $\begin{array}{l}14 \\
4\end{array}$ & $\begin{array}{l}\text { 18-May- } \\
15\end{array}$ & MatchMaking & Female & Huma & & Nangarhar & 766194231 \\
\hline $\begin{array}{l}14 \\
5\end{array}$ & $\begin{array}{l}\text { 17-May- } \\
15\end{array}$ & End Borrowers & Male & Ajmal & Owner & Nangarhar & 785541155 \\
\hline $\begin{array}{l}14 \\
6\end{array}$ & $\begin{array}{l}\text { 17-May- } \\
15\end{array}$ & End Borrowers & Male & Wahidullah & Director & Nangarhar & 799261471 \\
\hline $\begin{array}{l}14 \\
7\end{array}$ & $\begin{array}{l}\text { 17-May- } \\
15\end{array}$ & End Borrowers & Male & Ghulam Dastagir & Director & Nangarhar & 773133492 \\
\hline $\begin{array}{l}14 \\
8\end{array}$ & $\begin{array}{l}\text { 17-May- } \\
15\end{array}$ & End Borrowers & Male & Shirin Jan & $\begin{array}{l}\text { Deputy } \\
\text { Director }\end{array}$ & Nangarhar & 788272841 \\
\hline $\begin{array}{l}14 \\
9\end{array}$ & $\begin{array}{l}\text { 17-May- } \\
15\end{array}$ & End Borrowers & Male & $\begin{array}{l}\text { Mohammad } \\
\text { Ashraf }\end{array}$ & $\mathrm{CEO}$ & Nangarhar & 786669393 \\
\hline $\begin{array}{l}15 \\
0\end{array}$ & $\begin{array}{l}\text { 17-May- } \\
15\end{array}$ & End Borrowers & Male & Aimal & Owner & Nangarhar & 799344764 \\
\hline $\begin{array}{l}15 \\
1\end{array}$ & $\begin{array}{l}\text { 17-May- } \\
15\end{array}$ & End Borrowers & Male & Ahmad Zaki & Director & Nangarhar & 773319395 \\
\hline $\begin{array}{l}15 \\
2\end{array}$ & $\begin{array}{l}\text { 17-May- } \\
15\end{array}$ & End Borrowers & Male & Zamin & & Nangarhar & 707762454 \\
\hline $\begin{array}{l}15 \\
3\end{array}$ & $\begin{array}{l}\text { 17-May- } \\
15\end{array}$ & End Borrowers & Male & Tajul Haq & & Nangarhar & 700148549 \\
\hline $\begin{array}{l}15 \\
4\end{array}$ & $\begin{array}{l}\text { 17-May- } \\
15\end{array}$ & End Borrowers & Male & Attaullah & & Nangarhar & 776245514 \\
\hline $\begin{array}{l}15 \\
5\end{array}$ & $\begin{array}{l}\text { 17-May- } \\
15\end{array}$ & End Borrowers & Male & Khushal & & Nangarhar & 776974050 \\
\hline $\begin{array}{l}15 \\
6\end{array}$ & $\begin{array}{l}\text { 17-May- } \\
15\end{array}$ & End Borrowers & Male & Hakim & & Nangarhar & 700631691 \\
\hline $\begin{array}{l}15 \\
7\end{array}$ & $\begin{array}{l}\text { 17-May- } \\
15\end{array}$ & End Borrowers & Male & Ezatullah & & Nangarhar & 793971011 \\
\hline
\end{tabular}




\begin{tabular}{|l|l|l|l|l|l|l|l|l|l|}
15 & 16 -May- & Mobile Money & Male & Ghulam Sidiq & Director & EFGA & Nangarhar & 777613470 \\
\hline $\begin{array}{l}15 \\
9\end{array}$ & $\begin{array}{l}16-\text { May- } \\
15\end{array}$ & Mobile Money & Male & Sifatullah & Manager & & Nangarhar & 773102222 \\
\hline
\end{tabular}




\section{Methodology Description}

Final Performance Evaluation of Financial Access for Investing in the DEVELOPMENT OF AFGHANistan (FAIDA)

\section{Evaluation Methodology and Approach:}

The FAIDA evaluation covered five geographic locations: Kabul, Kandahar, Herat, Mazar, and Jalalabad. FAIDA's activities were not necessarily homogenous across all five geographic locations, and differing approaches were therefore required to evaluate its performance, especially at the Enterprise and Banking Capacity level, and Mobile Network Operators. In each region, the team met with both men and women owned MSME's, in order to determine whether the program has been successful at improving access to a diverse range of financial services.

Desk Review - The evaluation team reviewed a variety of program operational documents and reports provided by the USAID Contracting Officer Representative (COR), including: performance monitoring and evaluation reports; impact assessment and previous evaluation reports; implementation work plans; quarterly and annual implementation progress reports, and other Monitoring and Evaluation Documents within the FAIDA program.

Key Informant Interviews (KII)-The Evaluation Team held some face-to-face interaction with some of the key stakeholders involved directly and indirectly with the FAIDA program, including: the FAIDAs project staff and managers in Kabul and field offices; managers and Chief Executive Officers of key financial intermediaries and umbrella and supervisory bodies including: the Afghanistan Banks Association (ABA), Afghanistan Association of Microfinance (AMA), International Finance Cooperation (IFC) etc. Table 1 lists the organization consulted and the number of persons met in each. In total, the evaluation team met with 31 senior level officials including several CEO's.

Table 1: Organizations and Persons met by the FAIDA evaluation team

\begin{tabular}{|l|l|}
\hline Organization & Number of Person Met \\
\hline ABA & 2 \\
\hline AIBF & 1 \\
\hline AIPA & 1 \\
\hline AMA & 1 \\
\hline APS & 2 \\
\hline AWCC & 1 \\
\hline Etisalat & 2 \\
\hline FAIDA & 11 \\
\hline $\begin{array}{l}\text { FINCA } \\
\text { Afghanistan }\end{array}$ & 1 \\
\hline IFC & 1 \\
\hline
\end{tabular}




\begin{tabular}{|l|l|}
\hline IIFC & 1 \\
\hline KCCI & 1 \\
\hline MISFA & 1 \\
\hline OxuS & 2 \\
\hline $\begin{array}{l}\text { OXUS } \\
\text { Afghanistan }\end{array}$ & 2 \\
\hline Roshan & 1 \\
\hline Grand Total & $\mathbf{3 1}$ \\
\hline
\end{tabular}

Source: FAIDA Evaluation Tools

Interviews Focus Groups of Intermediaries and End Borrowers- The evaluation team developed tools for data collection which included

- enterprise level MSME end borrowers Focus Group questionnaires

- FAIDA Matchmaking Questionnaires

- Gender mainstreaming questionnaires

- Mobile Money End Used Questionnaire,

- Banking capacity component interview guides

Initially the evaluation team intended to invite 300 beneficiaries to participate in the focus groups discussions. In all the five evaluation program provinces of Kabul, Balkh, Herat, Kandahar and Nangarhar, the team interviewed 159 of FAIDA's beneficiaries ( 68 female and 91 male) mobile Money, Matchmaking, Women access to finance and end borrowers groups. Table 2 gives a breakdown of the surveyed beneficiaries by type of activity and provinces while table 3 gives the breakdown by province and gender

Table 2: Number of Beneficiaries Surveyed by Type of activity and Province

\begin{tabular}{|l|l|l|l|l|l|l|}
\hline Type & Balkh & Herat & Kabul & Kandahar & Nangarhar & $\begin{array}{l}\text { Grand } \\
\text { Total }\end{array}$ \\
\hline $\begin{array}{l}\text { End } \\
\text { Borrowers }\end{array}$ & 9 & 14 & 8 & 15 & 13 & 59 \\
\hline Gender & 8 & 12 & 8 & 3 & 7 & 38 \\
\hline $\begin{array}{l}\text { Match } \\
\text { Making }\end{array}$ & 11 & 16 & 6 & 9 & 2 & 44 \\
\hline $\begin{array}{l}\text { Mobile } \\
\text { Money }\end{array}$ & 3 & & 6 & 7 & 2 & 18 \\
\hline $\begin{array}{l}\text { Grand } \\
\text { Total }\end{array}$ & $\mathbf{3 1}$ & $\mathbf{4 2}$ & $\mathbf{2 8}$ & $\mathbf{3 4}$ & $\mathbf{2 4}$ & $\mathbf{1 5 9}$ \\
\hline
\end{tabular}

Source: FAIDA Evaluation Tools

Table 3: Number of Beneficiaries Surveyed by Province and Gender.

\begin{tabular}{|l|l|l|l|}
\hline Province & Female & Male & Grand Total \\
\hline
\end{tabular}




\begin{tabular}{|l|l|l|l|}
\hline Balkh & 18 & 13 & 31 \\
\hline Herat & 25 & 17 & 42 \\
\hline Kabul & 14 & 14 & 28 \\
\hline Kandahar & 4 & 30 & 34 \\
\hline Nangarhar & 7 & 17 & 24 \\
\hline Grand Total & $\mathbf{6 8}$ & $\mathbf{9 1}$ & $\mathbf{1 5 9}$ \\
\hline
\end{tabular}

Source: FAIDA Evaluation Tools

In each region the survey was administered in two sessions' individual interviews and focus groups. The interview and focus groups were also held separately for beneficiaries of Mobile Money, Matchmaking, Women access to finance and FI and Banking end borrowers. For security reasons, participants were asked to come to the places where the team was stationed including:

- Kabul- Checchi Office

- Nanagarhar- Checchi Office

- Kandahar- Intercontinental Hotel

- Balkh-Royal Oak Hotel

- Herat-Nazary Hotel

\section{Administration of FGD:}

First of all the teams introduced themselves and objective of the evaluation, and then gave everybody a questionnaire to complete individually followed by a general discussion session. The purpose of the general discussion session in the focus groups was to allow respondents the opportunity to discuss issues beyond what could be elaborated in the questionnaire.

\section{Changes in the Methodology:}

The initial approach was for the evaluation team to select 50 interviewees per province based on the list provided by FAIDA. The approach did not generate the numbers required. The evaluation decided to change the approach in Herat and to ask FAIDA to invite more people.

\section{Evaluation Constraints:}

The challenge the team faced was that turnout to the FGD was very low and in occasions it was zero. Some participants were unable to read or write forcing the evaluation team to assist them in completing the questionnaires which took longer than anticipated. Security is always a concern in the provinces where most of the beneficiaries are located in the districts, and it is difficult for them to travel specially for women. Since a number of questions during the interviews dealt with issues that took place in the past, most people invited did not know who FAIDA was as they may have participated in the matchmaking events two or three years back. Some respondents had difficult recalling accurately the role played by FAIDA.

Data Analysis The evaluation questions was analyzed according to the six evaluation questions in the SOW. Once a field work is completed in a province, the data collected were brought back to Kabul at the end of each mission. Data quality was checked, cleaned and 
entry done in Kabul Checchi Office. Quantitative data collected was analyzed using established evaluation techniques and standard data analysis tools. These tools enabled evaluators to evaluate not only descriptive statistics (such as the number of people surveyed, the percentage of female, and the number of respondents reporting a given problem or benefit) but also more advanced analytical exercises such as measures of correlation between various variables. The data is stored both soft and hard copies. 


\section{DATA Collection InSTRUMENTS}

\section{FINANCIAL ACCESS FOR INVESTING IN THE DEVELOPMENT OF AFGHANISTAN(FAIDA)}

\section{FOCUS GROUP QUESTIONS fOr END BORROWERS}

1. Would you have been able to successfully receive a loan or access to an Islamic or Sharia-compliant banking product without FAIDA's assistance or intervention?

2. In your experience, did your loan or Islamic or Sharia-compliant banking product meet the needs of your business?

3. Will the assistance FAIDA provided make it easier for you to get a loan or access an Islamic or Sharia-compliant banking product in the future?

4. If you have increased your business staffing, could you have accomplished that increase without FAIDA's assistance?

5. Does your business accept Mobile Money for purchase of goods or does your business pay for goods through Mobile Money? If yes, has the number of Mobile Money transactions expanded over time?

6. If you were managing the FAIDA program, what would you do to improve FAIDA assistance? Please comment:

\section{FINANCIAL ACCESS FOR INVESTING IN THE DEVELOPMENT OF AFGHANISTAN (FAIDA)}

\section{QUESTIONNAIRE for ENTERPRISE COMPONENT END- BORROWERS}

The information provided during this interview will be treated as highly confidential and is collected for evaluation purposes only. The purpose of this evaluation is simply to gain a better understanding of the FAIDA program. Therefore, we ask you to feel at ease and to provide us with frank and honest answers without fearing any disclosure. The evaluator is only interested in the analysis of the overall feedback provided and not in the individual information you provide.

\section{Basic Information:}




\section{Province:}

( ) Kabul

( ) Nangarhar

( ) Herat

( ) Balkh

( ) Kandahar

Gender: ( ) Male ( ) Female

Interview Date:

1. Is your business fully woman-owned, partially woman owned or neither? Please select one of the answers below:

( ) Fully woman-owned

( ) Partially woman-owned

( ) Not fully woman-owned or partially woman-owned

2. What type of business do you own or work for? Please check all those that apply:

( ) Agricultural grower or farmer

( ) Agricultural distributor

( ) Agricultural equipment

( ) Agricultural related, but not a grower, distributor or seller of agricultural equipment

( ) Manufactures goods

( ) Wholesales goods

( ) Transports goods

( ) Retails produce or goods or I am a shop owner

( ) Other - Please tell us below:

Comments:

3. I own or operate more than one business?
( ) Yes
( ) No
( ) Does not apply

4. Year of establishment of your primary business: ( )

5. How many members or workers does your organization have?

Members: Male ( ) Females ( )

Workers: Male ( ) Females ( ) 
6. Is your business in a value chain that markets agricultural products or non-agricultural products?

( ) agricultural products

( ) non-agricultural products

7. Did FAIDA assistance help you to become a member of the value chain entity?

( ) Yes

8. Does your business have a fixed price contract for the sale of your produce or goods?
( ) Yes

( ) No

9. Does your business sell agricultural products or goods internationally?
( ) Yes
( ) No

10. Is selling agricultural products or goods internationally in your business plan?
( ) Yes
( ) No

11. If selling agricultural products or goods internationally is not in your business plan, would you like FAIDA assistance in developing a business plan to sell your produce or goods internationally?
( ) Yes
( ) No

12. Did FAIDA provide you or your business with direct assistance?
( ) Yes
( ) No

Please comment:

13. Did FAIDA provide you or your business with indirect assistance through another organization? 

( ) Yes
( ) No
Please comment:

14. What assistance did you receive from FAIDA? Please mark all those that apply:
( ) Grant
( ) Workshop
( ) Business to Bank Roundtable
( ) Business to Business Roundtable
( ) Conference
( ) One on one assistance
( ) Attendance at a trade exhibition or fair featuring Afghan goods
( ) Member of a delegation to another country to promote the sale of Afghan products
( ) Previously FAIDA assistance in developing business concept notes
( ) Previously FAIDA assistance in developing a business loan application
( ) Previously FAIDA assistance in developing a business plan
( ) FAIDA is currently assisting me in developing my business concept notes
( ) FAIDA is currently assisting me in applying for a business loan
( ) Other - Please tell us below:

15. Did FAIDA assisted you in securing a conventional loan?
( ) Yes
( ) No

16. Did FAIDA assist you in securing an Islamic or Sharia-compliant banking product?
( ) Yes
( ) No

If the answer was "Yes", please tell us what type of Islamic or Sharia-compliant product was secured?

17. Did FAIDA assistance help you to expand your business contacts?
( ) Yes
( ) No

Please comment:

18. Did FAIDA assistance help you increase your business sales?
( ) Yes
( ) No

Please comment: 
19. Did FAIDA assistance help you increase your business profits? Please mark one of the following:

( ) Significant expansion

( ) Some expansion

( ) No expansion

20. Did FAIDA assistance help you to expand the number of employees or members of your business?

( ) Yes

( ) No

21. If FAIDA assistance helped you expand the number of employees or members of your business, how large was the expansion?

( ) Male ( ) Female

22. If FAIDA assistance helped you to expand your business, how long did the expansion require?

Please estimate for us:

23. If your business expanded, did you hire any additional female workers?

( ) No

If yes, how many female workers did your business add? ( )

24. Are you attempting to expand your business?
( ) Yes
( ) No

Please comment:

25. Do you understand what additional assistance FAIDA can provide to your business?
( ) Yes
( ) No 
26. If you do not understand what additional assistance FAIDA can provide to your business, what can FAIDA do to help you better understand?

Please tell us:

27. If you would like to expand your business or become more profitable, what assistance that FAIDA currently offers would be of most help?

Please tell us:

28. If you would like to expand your business or become more profitable, what new or different assistance would you like FAIDA to offer?

Please tell us:

29. If you are satisfied with the size or sales of your business, what assistance could FAIDA offer to help your business become more profitable?

Please tell us:

30. If you are happy with FAIDA assistance, do you recommend FAIDA assistance to your business friends and associates? If yes, please tell us what type of FAIDA assistance you recommend to them:

( ) Yes

( ) No

Comments:

This was a long questionnaire and we asked you to provide a lot of information. 
Thank you for taking the time to complete the questionnaire.

\section{FINANCIAL ACCESS FOR INVESTING IN THE DEVELOPMENT OF AFGHANISTAN (FAIDA)}

FOCUS GROUP QUESTIONS for MATCH MAKING ACTIVITIES

1. Were your expectations met when you attended the meeting.

2. Do you feel that FAIDA matchmaking activities were successful in linking your business with financial institutions or improving your business contacts?

3. How could FAIDA change its matchmaking activities to make them more effective?

4. What advice would you give to someone attending a FAIDA matchmaking activity for the first time?

FINANCIAL ACCESS FOR INVESTING IN THE DEVELOPMENT OF AFGHANISTAN (FAIDA)

QUESTIONNAIRE for MATCH MAKING ACTIVITIES

Date:

$\begin{array}{ll}\text { Gender: } & \text { Province: } \\ & \\ \text { ( ) Male } & \text { ( ) Kabul } \\ \text { ( ) Female } & \text { ( ) Nangrahar } \\ & \text { ( ) Herat } \\ & \text { ( ) Balkh } \\ & \text { ( ) Kandahar }\end{array}$

Mobile

Agent

Merchant:

Network

Operator:

1. In what sector do you primarily work?

( ) Agriculture

( ) Non-Agriculture

2. What type of FAIDA matchmaking event did you attend? Please mark all that apply. 

( ) Business Roundtable
( ) Innovation Fair
( ) Conference
( ) Workshop
( ) Other - Please tell us what other type of matchmaking activity you attended?

3. Did FAIDA matchmaking assistance include developing business concept notes?
( ) Yes
( ) No

4. Did FAIDA matchmaking assistance include developing a loan application?
( ) Yes
( ) No

5. Did FAIDA matchmaking activities assist you in securing a conventional loan?
( ) Yes
( ) No

6. Did FAIDA matchmaking activities assist you in securing an Islamic or Shariacompliant banking product?
( ) Yes
( ) No

If the answer was "Yes", please tell us what type of Islamic or Sharia-compliant product was secured?

7. Do you think the FAIDA matchmaking assistance will help you secure financing in the future?
( ) Yes
( ) No

8. Did FAIDA matchmaking assistance help you to expand your business contacts or business markets?
( ) Yes
( ) No

How:

9. If you participated in a FAIDA Innovation Fair, and your concept was selected for implementation, do you know if it was implemented?

( ) Yes, my concept was selected and implemented. 
( ) My concept was selected, but it was not implemented.

( ) My concept was selected, but I do not know if it was implemented.

10. Were the types of financial institutions present at the FAIDA matchmaking activity appropriate for your financial needs? If not, please tell us what types of financial institutions you would like to see at these activities?

( ) Yes

(

No

Comment:

11. Would you like to see more matchmaking with financial institutions that offer Islamic or Sharia compliant banking products?

( ) Yes

( ) No

12. Were you able to expand your business through FAIDA matchmaking activities?
( ) Yes
( ) No

13. If you were able to expand your business through FAIDA matchmaking activities, did you add any additional staff to your business?
( ) Yes
( ) No

14. If you added additional staff as a result of FAIDA matchmaking activities, how many staff did you add? Number of men? Number of women?

15. Would you attend another FAIDA matchmaking activity if invited?
( ) Yes
( ) No

16. Would you recommend FAIDA matchmaking activities to your business friends and associates?

\section{FINANCIAL ACCESS FOR INVESTING IN THEDEVELOPMENT OF AFGHANISTAN (FAIDA)}

GENDER MAINSTREAMING FOCUS GROUP QUESTIONS 
1. What are the problems you face in operating or attempting to start a women-owned business?

2. After attending the FAIDA sessions, do you feel you more confident that you understand technical business issues such as business planning and marketing?

3. After attending the FAIDA sessions, do you feel more confident that you are able to access bank loans or Islamic or Sharia-compliant banking products?

4. After attending the FAIDA sessions, have you been able to start a business or expand your business?

5. Would you recommend FAIDA sessions to other women in business or women who would like to start a business?

\section{FINANCIAL ACCESS FOR INVESTING IN THEDEVELOPMENT OF AFGHANISTAN (FAIDA)}

\section{GENDER MAINSTREAMING QUESTIONNAIRE}

The information provided during this interview will be treated as highly confidential and is collected for evaluation purposes only. The purpose of this evaluation is simply to gain a better understanding of the FAIDA program. Therefore, we ask you to feel at ease and to provide us with frank and honest answers without fearing any disclosure. The evaluator is only interested in the analysis of the overall feedback provided and not in the individual information you provide.

\section{Basic Information:}

Province:

( ) Kabul

( ) Nangrahar

( ) Herat

( ) Balkh

( ) Kandahar

Interview Date: 
Do you:

( ) Own or operate a business? Please answer questions 2 through 28.

( ) Would like to own or operate a business? Please answer questions 29 through 37.

( ) Work for a business you do not own. Please discuss with your moderator.

1. What type of business do you own? Please check all those that apply:

( ) Retail produce or goods or a shop owner

( ) A home business

( ) Agricultural grower or farmer

( ) Agricultural distributor

( ) Agricultural equipment

( ) Agricultural related, but not a grower, distributor or seller of agricultural equipment

( ) Manufacturer

( ) Wholesaler of goods

( ) Transporter of goods

( ) Other - Please tell us below:

Comments:

2. I own or operate more than one business?

( ) Yes

( ) No

( ) Does not apply

3. Year of establishment of your primary business:

4. How many members or workers does your organization have?

Members: Male ( ) Females ( )

Workers: Male ( ) Females ( )

5. Is your business in a value chain that markets agricultural products or other goods?

( ) Yes

( ) No

6. If your business is in a value chain organization, did FAIDA assistance help you to become a participant in the value chain organization?

( ) Yes 
( ) No

7. Does your business have a fixed price contract for the sale of your produce or goods?

( ) Yes

( ) No

8. Does your business sell produce or goods internationally?

( ) Yes

( ) No

9. Is selling produce or goods internationally in your business plan?

( ) Yes

( ) No

10. If selling produce or goods internationally is not in your business plan, would you like FAIDA assistance in developing a business plan to sell your produce or goods internationally?

( ) Yes

( ) No

11. Did FAIDA provide you or your business with direct assistance?

( ) Yes

( ) No

Please comment:

12. Did FAIDA provide you or your business with indirect assistance through another organization?

( ) Yes

( ) No

Please comment:

13. What assistance did you receive from FAIDA? Please mark all those that apply: 

( ) Grant
( ) Workshop
( ) Business to Bank Roundtable
( ) Business to Business Roundtable
( ) Conference
( ) One on one assistance
( ) Attendance at a trade exhibition or fair featuring Afghan goods
( ) Member of a delegation to another country to promote the sale of Afghan products
( ) Previously FAIDA assistance in developing business concept notes
( ) Previously FAIDA assistance in developing a business loan application
( ) Previously FAIDA assistance in developing a business plan
( ) FAIDA is currently assisting me in developing my business concept notes
( ) FAIDA is currently assisting me in applying for a business loan
( ) Other - Please tell us below:

14. Did FAIDA assisted you in securing a conventional loan?
( ) Yes
( ) No

15. Did FAIDA assist you in securing an Islamic or Sharia-compliant banking product?

\section{( ) Yes}

( ) No

If the answer was "Yes", please tell us what type of Islamic or Sharia-compliant product was secured?

16. Did FAIDA assistance help you to expand your business contacts?

( ) Yes

( ) No

Please comment:

17. Did FAIDA assistance help you increase your business sales?

( ) Yes

( ) No

Please comment:

18. Did FAIDA assistance help you increase your business profits? Please mark one of the following:

( ) Significant expansion

( ) Some expansion 
( ) No expansion

19. Did FAIDA assistance help you to expand the number of employees or members of your business?

( ) Yes

( ) No

Please tell us about that:

20. If FAIDA assistance helped you expand the number of employees or members of your business, how large was the expansion?

( ) Male

( ) Female

21. If FAIDA assistance helped you to expanded your business, how long did the expansion require?

( ) Less than six months

( ) Over six months

22. Do you understand what additional assistance FAIDA can provide to your business?

( ) Yes

( ) No

23. If you do not understand what additional assistance FAIDA can provide to your business, what can FAIDA do to help you better understand?

Please tell us:

24. If you would like to expand your business or become more profitable, what assistance that FAIDA currently offers would be of most help?

Please tell us: 
25. If you would like to expand your business or become more profitable, what new or different assistance would you like FAIDA to offer?

Please tell us:

26. If you are happy with FAIDA assistance, do you recommend FAIDA assistance to your business friends and associates? If yes, please tell us what type of FAIDA assistance you recommend to them:

( ) Yes

( ) No

Comments:

27. What type of business would you like to start? Please check all those that apply:

( ) Retail produce or goods or a shop owner

( ) A home business

( ) Agricultural grower or farmer

( ) Agricultural distributor

( ) Agricultural equipment

( ) Agricultural related, but not a grower, distributor or seller of agricultural equipment

( ) Manufacturer

( ) Wholesaler of goods

( ) Transporter of goods

( ) Other - Please tell us below:

Comments:

28. What assistance did you receive from FAIDA? Please mark all those that apply:

( ) Grant

( ) Workshop

( ) Business to Bank Roundtable

( ) Business to Business Roundtable

( ) Conference

( ) One on one assistance

( ) Attendance at a trade exhibition or fair featuring Afghan goods

( ) Member of a delegation to another country to promote the sale of Afghan products

( ) Previously FAIDA assistance in developing business concept notes

( ) Previously FAIDA assistance in developing a business loan application 
( ) Previously FAIDA assistance in developing a business plan

( ) FAIDA is currently assisting me in developing my business concept notes

( ) FAIDA is currently assisting me in applying for a business loan

( ) Other - Please tell us below:

29. After receiving FAIDA assistance, have you attempted to start your business?

( ) Yes

( ) No

30. Did FAIDA assistance make it easier for you to understand how to start a business?

( ) Yes

( ) No

31. Did FAIDA assistance provide you with the technical skills to develop a business concept?

( ) Yes

( ) No

32. Did FAIDA assistance help you to understand how to develop a business plan for the business you would like to start?

( ) Yes

( ) No

33. Did FAIDA assistance help you to become more comfortable in knowing how to approach a bank for a loan or Islamic or Sharia-compliant banking product?

( ) Yes

( ) No

34. Overall, will the assistance FAIDA provided enable you to start the business you have desire?

( ) Yes

( ) No 
35. If you are happy with FAIDA assistance, do you recommend FAIDA assistance to your business friends and associates? If yes, please tell us what type of FAIDA assistance you recommend to them:

( ) Yes

( ) No

Comments:

This was a long questionnaire and we asked you to provide a lot of information.

Thank you for taking the time to complete the questionnaire.

FINANCIAL ACCESS FOR INVESTING IN THE DEVELOPMENT OF AFGHANISTAN (FAIDA)

FOCUS GROUP QUESTIONS for MOBILE MONEY AGENTS/MERCHANTS

1. As a Mobile Money Agent, how do you view the program?

2. How difficult is it to convince people to use Mobile Money?

3. Do your customers accept the Money Mobile program or do they resist it?

4. In what ways do you see the use of Mobile Money expanding?

FINANCIAL ACCESS FOR INVESTING IN THE DEVELOPMENT OF AFGHANISTAN (FAIDA)

QUESTIONNAIRE for MOBILE MONEY AGENTS/MERCHANTS

Date: Gender: Province: MNO: Type
( ) Male ( ) Kabul
( ) Agent
( ) Female
( ) Nangrahar
( ) Merchant
( ) Herat
( ) Balkh
( ) Kandahar

1. How long are have you been a Mobile Money agent/merchant?

( ) Less than 6 months 
( ) 6 Months to 1 year

( ) Over 1 year

2. If you are an Agent, is being a Mobile Money agent your primary business?

( ) Yes

( ) No

3. If No, what is your primary business?

4. If you are a Merchant, has Mobile Money assisted in expanding your business?
( ) Yes
( ) No

5. IF YES, by how much? Please provide a percentage?

6. How many customer transactions do you process in a month?

7. How many Mobile Money transaction have you processed since becoming an Agent/Merchant?

8. What type of transactions do you process?
( ) Cash
( ) In kind

9. Are the number of Mobile Money transactions increasing every month? If yes, by what percent?

10. Is the profit you earn from being a Mobile Money Agent/Merchant reasonable?
( ) No Profit
( ) Not reasonable
( ) Reasonable
( ) Excellent

11. Do you provide awareness to others of the Mobile Money program?
( ) Yes
( ) No

12. If Yes, how do you provide the awareness, through groups or individually?

( ) Groups 
( ) Individually

13. Do you think your customers are happy with the Mobile Money program?

( ) Yes

( ) No

14. Did you receive Mobile Money Agent training?

( ) Yes

( ) No

15. If yes, what was the subject of the training?

16. Who trained you?

17. Do you intend to continue to be a Mobile Money Agent?

( ) Yes

( ) No

Please explain Why or Why not?

\section{FINANCIAL ACCESS FOR INVESTING IN THE DEVELOPMENT OF AFGHANISTAN (FAIDA)}

\section{INTERVIEW GUIDE for BANKING CAPACITY COMPONENT}

(Including Associations, individual banks, and MFI's)

This protocol is for the purpose of conducting an independent assessment of the Financial Access for Investing in the Development of Afghanistan (FAIDA) funded by USAID. The information gathered by way of this questionnaire will be used for that purpose only.

7. Name of Organization:

Date:

Region:

Type of Organization:

Name \& position of person responding/completing this questionnaire:

Address:

E-mail Address (if any):

Telephone Number:

2. What FAIDA assistance was received? Please mark all that apply:

( ) Capacity building assistance for individuals in your organization? 
( ) Capacity building assistance for how your organization operates?

( ) Capacity building assistance for individuals in your member organizations?

( ) Grant?

( ) Professional research or advise on how to address banking sector issues or problems?

( ) Interns for my organization?

( ) Other - Please tell us what other assistance was provided?

3. Was the assistance which you requested or was it proposed by FAIDA?

( ) Our organization proposed the assistance that was needed to FAIDA.

( ) The assistance was proposed by FAIDA to my organization.

4. Has FAIDA assistance enhanced the capabilities of your organization's professionals, or enhanced the capabilities of your member organizations professionals, or improved the effectiveness of your organization to advocate for needed policy or regulatory changes?

( ) Yes

( ) No

If the answer is "Yes", please tell us how FAIDA assistance contributed to building that capacity?

5. If FAIDA assistance has not been helpful, please tell us why?

6. If FAIDA provided Training assistance, how many employees received training?

Number of Male: Number of Female:

7. How many of those trained were in junior positions? Male:

Female:

8. How many of those trained were in senior positions? Male:

Female:

9. If FAIDA provided a grant:

What was the size of the grant?

How were the proceeds of the grant utilized?

Did the grant make a difference in improving your organizations operations or efficiency or did assist in building the capacity of member organizations? If the answer is "Yes", please tell us how?

10. If further FAIDA assistance were to be available, what area(s) of your organization or your member organizations have an urgent need for assistance? 
11. Do you have any specific recommendations or suggestions to make to FAIDA, related to:

a) The support of women oriented to, and/or, managing, business;

b) The development of the financial industry, and the creation of jobs;

c) The provision of additional training courses or other forms of knowledge enhancement for financial sector employees;

d) The financial sector generally?

\section{THANK YOU}

\section{FINANCIAL ACCESS FOR INVESTING IN THE DEVELOPMENT OF AFGHANISTAN (FAIDA)}

\section{QUESTIONS FOR INTERVIEWS WITH MOBILE MONEY NETWORK OPERATORS}

The information provided during this interview will be treated as highly confidential, and is only collected for the purposes of evaluation. The evaluators are only interested in analysis of collective feedback, and not individual respondent information.

1. How important was the assistance of FAIDA in moving the mobile money project forward?

2. FAIDA sponsored an Innovation Project with regard to new Mobile Money apps. Were any of these apps implemented and did implementation result in increased Mobile Money activity?

3. For marketing purposes, do you anticipate a nationwide implementation of Mobile Money for your operation, or do you expect to focus on a particular geographic area?

4. Do you feel you have enough Mobile Money Agents in Kabul and in the Provinces?

5. Has FAIDA assisted you in developing qualified Mobile Money Agents?

6. Has there been any significant change in the number of mobile money participants or overall activity? If so, are you able to identify any particular reason for the increase? 
7. In your opinion, what changes would be necessary to increase usage of the product?

8. In your opinion, if the banks were to have interchangeability between mobile money and their payments system, would that make a significant difference?

9. Are there any regulatory inhibitors to the future development of mobile money?

10. Will receiving government salary by Mobile Money be essential to the long term success of Mobile Money?

11. Does your version of Mobile Money offer interoperability with the customer's bank accounts? If yes, has this feature increased the acceptance of Mobile Money?

Thank you.

\section{FINANCIAL ACCESS FOR INVESTMENT IN THE DEVELOPMENT OF AFGHANISTAN (FAIDA)}

\section{CENTRAL BANK (DAB) INTERVIEW GUIDE}

The information provided during this interview will be treated as highly confidential and is collected for evaluation purposes only. Evaluators are only interested in analysis of collective feedback and not individual respondent information.

1. What are your views on FAIDA's approach to improving the enabling environment for private-sector led development?

2. In your view, have the ideas, proposed by FAIDA, for new or updated regulations, been both reasonable and necessary?

3. Will these new regulations assist in making access to credit easier, particularly in rural areas, and for women entrepreneurs?

4. Overall, do you think that the FAIDA project has succeeded in improving and widening the capacity of the financial sector?

5. FAIDA has facilitated training programs for the financial sector and its employees, primarily through the Afghanistan Institute of Banking and Finance. Do you believe that this has been successful, and would you like to see further training programs? 
6. As the Central Bank of Afghanistan, what do you see as the next step to widening both the availability and use of the mobile banking program?

7. Would you like to see similar programs to FAIDA, and, if so, how would you like to see them structured? 


\section{Detailed Meeting Notes}

09-May-2015

Afghanistan Insurance Personnel Association (AIPA)

- Met with:

- Fahad Daud Momand, also CEO, Afghan National Insurance Company CEO

- Association established so that Afghanistan's insurance companies could speak with a single voice

- Members:

- Afghan National Insurance Company (ANIC)

- Afghan Global Insurance (AGI)

○ Member in principle only - Insurance Company of Afghanistan (ICA)

- FAIDA supported:

○ Access to Finance meetings

○ Insurance industry meetings

- Dubai Insurance meeting - paid accommodations and fees

○ Staff Trainings

○ Articles [“of incorporation"]/bylaws for Association

- Paid licensing fees (40,000 AFs) for AIPA

- Provided generator and office furniture

- Wrote letters to regulators and others

- Says FAIDA support "so - so"

- Says FAIDA good at writing

- Says FAIDA takes too long to make decision

- Afghanistan needs to consider compulsory insurance for issues like traffic insurance/fire

- Says banks do not understand compulsory insurance for loans/collateral is way of managing risk

- ACCI rejected because not all members were on board

- Association members volunteering time without compensation

- Outreach to other countries with more established market:

- Association has signed MOU with Jordan

- Planning a trip to Thailand

- Regarding Insurance Professionals:

- Since 1964 there has been significant attrition in Afghan insurance professionals

- Difficult to find insurance SME's - most have retired and there is no succession plan

- Need to involve Kabul University Professors/Kabul University

- Expanding market:

- Insurance policies are written in English and are difficult for most to understand

- Would like to see American donors with DBA insurance required to purchase policies through Afghan companies

- Says can lay off part of DBA risk through reinsurance outside Afghanistan 
- Says now laying off part of Fire insurance through reinsurance

- Provided examples of successful insurance claim benefits paid:

- Ariana crash - paid out hull insurance

- Carpet store in Jalalabad burned - contents not insured, but building covered and claim paid

o Tried to develop basic healthcare policy/system [similar to HMO]:

- Ins co's would provide service/pay claims locally for typical needs

- Ins co's would leverage other resources for needed complicated surgery in other Afghanistan facilities or, if needed, outside country

- Ins co's would provide pharmacy with drugs for sale not commonly stocked

- AIPA needs:

○ Budget support

- Technical support

- Technical capacity building

- Study trips to countries with more well established insurance markets and trade associations

- Assistance with marketing to banks and general public

- Assistance in developing standardized policies

- Assistance with improving claims processing process

- Assistance in developing awareness among general public regarding benefits of insurance

- Provincial expansion of offices

- Assistance in supporting dedicated staff

- AIPA requested from FAIDA:

- Says asked for help in establishing pilot program for Provincial offices

$\circ$ AIPA requested grant from FAIDA for budget support (budget was approved by members)

O Says has not heard anything yet - communication could be better back from FAIDA

09-May-2015

Afghanistan Banks Association (ABA)

Met with:

- Abdul Majeed Jabarkhail - Executive Director

- Najibullah Amiri Deputy Executive Director (Head of Administration/Finance)

- Says relatively new (2004) and meant to be independent

- Members are 15 banks (Foreign branches do not like to pay membership fees)

- Membership income does come close to sustaining ABA

- $47 \%$ (49\%?) shareholder in Afghanistan Institute of Banking and Finance (AIBF)

- $\mathrm{DAB}$ is a major shareholder in MIFSA [?] 
- $\mathrm{ABA}$ and AIBF collaborating on curriculum development

- ABA and Afghanistan Microfinance Association (AMA) working together

- Banking environment:

○ Deposits up $12 \%$

○ Loans down

- Staff of 14 vs 8,000 bankers in Afghanistan

- Also working with Harakat on conventional banking vs. Islamic products issues

- FAIDA:

- Helped establish legitimacy of ABA

- Provided $\$ 500,000$

- Says little direct support, says most FAIDA support goes to banks

- Provided STTA regarding original structure

- Provided assistance in developing promotional material

- Open to discussion and STTA recommendations

- Strategic Plan assistance "a bit slow"

- Says need TOR for Expat Legal Advisor - how much commitment to ABA?

- Outstanding issues:

- DAB regulations written in English

- Says misperception in Afghanistan regarding Islamic banking - need awareness campaign

- Property appraisal issues are challenging

- Who will license?

- Who will monitor?

- Need Short Term Technical Assistance (STTA) at ABA and DAB

- Says need more input into hiring Advisors - example was local legal advisor

- Says Property Appraisal issues need to be settled in order to develop mortgage market

- Says FAIDA provided Anti-money Laundering (AML) training provided to DAB

- Says did not assist in developing Credit Registry or Collateral Registry [?]

- Exhibitions[?]

- ALBA Project [?]

- ABA needs:

- Increase confidence of public and Members in ABA

- Help in establishing contacts:

- Exposure visits to other countries

- With regional banking associations

- Strategic association with other Associations

- Assistance in becoming sustainable

- To assist members in explaining Islamic banking products to [potential] customers

- Additional staffing - especially legal staff

- Sector needs:

$\circ$ Credit training 
○ Operations training

- Special courses

- To resolve issue related to length of time needed for collateral liquidation

- ABA does not need STTA assistance regarding Islamic Bank regulation

- Risk Management

- An important issue

- Framework is in place

○ Ready to be piloted

- $\mathrm{AIBF}$

○ Now NGO - to be converted to a commercial entity

- FAIDA could help with linkages

Afghanistan Institute of Banking and Finance

Met with:

Mr. Sayed Abdul Ghafoor Sadat - Executive Director since Feb-2014

- Says original agreement with FAIDA extended from Dec 2012 to May 2013

- Says targets were not met because no basis for targets

○ Says has capacity to train $850-900$ per year

- Under his administration:

- Developed Islamic and Micro-finance modules

- Trained more than 990 since Feb 2014

○ Reduced costs by $53.67 \%$

- Issues:

- Constraints:

- Limited budget for trainers $(\$ 2,200)$

- Can not hire experienced banking staff with available budget and market availability

○ Need to:

- Hire adjunct staff

- Enlist assistance from bank Subject Matter Experts

○ World Bank:

- Training target 1500 vs Actual of 4,000+

- Made commitment to be self-sustaining in five years from assistance and that is not attainable

- AIBF generating income equal to $5 \%$ of expenses

○ Says organizational and personnel conflicts

- Says internal performance problems

- Says administrative problems with space leases and move

- Says tax filing problems

- Says external university MOU problem [Kampala] and diplomas not issued

- AMA Partnership Agreement not signed

- FAIDA withholding support until internal issues resolved

- Good news:

○ Says Course Evaluations very positive 
○ Says AMA is cooperating

- Needs:

○ International Advisors:

- Commercial banking

- Micro-banking

- Islamic financial products

- Cooperation from ABA Regional offices

- ACCA material??

- ABA relationship??

- Glen Tasky???

IIFC

Met with:

Bashir Mohammad Khan - Chief Executive Officer

- About IIFC:

○ Micro-Finance Institution (MFI)

- In 14 Provinces

- Has 31 Islamic branches

- Primarily business and agricultural lending

- Responsive to local requirements

- In Kunar loans to individuals

- Many loans in Kandahar

- Says is sustainable organization

- Lending range $-10,000 \mathrm{Afs}$ to $500,000 \mathrm{Afs}$

○ Wants "Smart growth"

- Has 5 regional offices

- Has strong monitoring department with help from FAIDA

- Heavy monitoring of borrowers (inventory levels, etc)

- Stock reports/trends

○ Operationally strong

o Financial statements

- Regarding FAIDA:

○ Provided training and capacity building

- Software upgrades to Microbanker $(\$ 50,000)$

- Provided matchmaking opportunities

- Assistance was helpful

- Lucky to find FAIDA assistance

- Very supportive

- Have collaborative relationship

- Assists in business analysis of borrowers

- Provided Advisor

- Refers/introduces good clients - decisions based upon IIFC standards

○ Will provide Mobile Money training 
○ Will help find donors

- Very responsive

$\circ$ Introduces products and opportunities

- 6Million repaid

○ Has 3.6Million line of credit

- Offered proposal for Women's IFC - says never heard back

- Says doing well, but others say slow to respond (sometimes takes a month)

- Internships?

○ None

- Not averse, but need internal capacity first

- Must build borrowers capacity first

- Mobile Money?

○ Looking at in far or insecure provinces

- Possible collection of remittances

- Concerned about charges - is major obstacle

- Possible replacement for collectors

- Women Customers?

○ Developing products for women

- Repayment terms important

- FAIDA women's staff went to Provinces helped with matchmaking

$\circ$ Also need to increase women staff to encourage - security is important

- Needed?

○ Accountants

- Basic accounting training (1 week to 2 weeks)

- Matchmaking assistance from FAIDA

- Says AIBF too expensive

Afghanistan Microfinance Association (AMA)

Met with:

Najibullah Samim - Executive Director

- Dormant until MIFSA and FAIDA involvement (only one employee)

- FAIDA support:

- Organizational Assessment (said AMA needed to expand base of MFI's)

- Financial and technical support

○ Infrastructure support

- Helped perception of AMA

- Support for salaries

○ Support for EF\&F

○ Training assessment for sector in 2012

- Salary survey for sector (very helpful)

○ Very helpful

- Started Microfinance for Women-transitioned to AMA-provided TOT 
○ Says happy with it

- Takes too long to receive response-expects to hear in a couple of months

- Helped to build AMA credibility

○ Only raises $10 \%$ of costs through fees-now funded $90 \%$ through MISFA

- AMA Activities:

- Conducted second salary assessment itself (FAIDA built capacity)

- Transitioned regional offices from MISFA

- Transitioned advocacy, communications and lobbying from MISFA

- Contributing to filing gaps not covered by AIBF

- Monthly meetings now for CU's now in Regions

- Microview Software

- MicroMag twice per year

- Women in Finance - took over from FAIDA

$\bigcirc$

- AMA Needs:

- Asked FAIDA TA -“They are open to it"

- Funding for MFI's-says can not raise enough-says same in other countries

○ Applying for grants-July 2015 through October 2015

- Mobile Money

- Says will eventually catch on

- Only a few MFI's have Mobile Money

- Some problems with Mobile Money

- Says fees may not be barrier-interest in the product may be the issue

$\circ$ Having options is important

- Women in Finance Interns

- Three rounds of interns

- AIBF and FAIDA placed interns

- Was not happy with quality of intern trainings

- Says not necessarily a good match between major field of study and banking

- Asked "After 6 mos of AIBF training, what happened?"

- Wanted to hire 2

- Interns could not articulate what they learned at AIBF

- Training

- AIBF quality and content of training declined

- Proposed joint AMA-AIBF training

- MFI's not necessarily happy with AIBF training

○ Wants "exposure" MFI to MFI training (peer/best practice training)

- Senior Managers need scholarships to continue training

- AMA will do Islamic financing training

- Regulatory

- Deposit taking DMFI reg -Needs to be fine-tuned (FAIDA and MISFA to handle)

○ Overall MFI Reg 
- Not in place

- MIFSA taking the lead

○ Credit Registry helpful?

- AMA took over from MIFSA

- Reduced fees for banks

- Support needed

○ Women in Finance

○ Institutional

○ Need institutional impact study

Add Roshan notes

Roshan

Spoke with:

Liaquat Ali Shad - Manager Strategic Products and Business Development, M-Paisa

- FAIDA grant

○ Roadshows

- Platform development

- Good for MFI borrowers

- More borrowers

○ Repay through MPaisa

- Received two Innovation Project apps

- Not implemented - MPaisa not profitable

- Each MNO given two apps - MNO's did not select

- Market now mostly in Kabul, Herat and Mazar (4???)

- Now targeting remote areas

- Agents are not an issue - have enough qualified Agents

- FAIDA matchmaking for Agents

○ Yielded no new Agents

○ Did not have technical training - matchmaking only

- Mobile Money participants

- Volume of participants up and down depending upon donor projects

- Participation dependent upon salary of clients

- What is needed to increase participation

- Six to seven years of experience - not yet profitable

- Says industry needs \$30-\$40Million in investment - could be shared by MNO's

○ Would work out in 4-6 years

- Conclusion

- Agents in place, but failed to increase profitability

- Customers in place, but failed to increase profitability

- Technology model in place is incompatible with market

- Tries to coordinate through AMOA

Etisalat 
Spoke with:

Bilal Anjum - mHawala Chief Internal Auditor

Hayatullah "Salarzai" - mHawala Senior Analyst

- mHawala spun off into separate wholly-owned Corporate entity-Restructuring in process

- Processing electrical bills

- DABS and AUB

- Kandahar and Kabul

○ Utilizing Afghan United Bank

- Both individuals and businesses utilize services

- Support from FAIDA

○ 2011 \$1Million for three years

○ 2012 and 2013 support continued - declined in 2014

- Applied for new Grant since new government in place

- mHawalah

○ 200 Agents

○ 40,000 DABS customers

○ 5 Women agents from FAIDA activities (1000 prospective, 200 short listed, 5 selected)

- Agents expected to market services

- There is a fee schedule for services

- Agents receive incentives and commissions

- Merchants have been contracts to provide support

- GIRoA salary payments expected

$\circ$ Will pay e-money internally

- Women's issues - ;looking for assistance in added women

- Relationship to APS

○ Banks own APS

- Requires substantial buy-in to join APS

- MNO and banks to use same middleware

- Successes?

- Experienced growing pains

- Plan for future

○ Salary payments

- First, internal salary payments

- Then, Kabul

- Then, 5 Regions

- Last, RFP for nationwide implementation

- Next month live across Afghanistan for basic service

- Tax payments, such as rental tax (BIS)

- Rental payments

- Awareness!! Is the key to expansion

- Sees long-term plan as incremental

- Part of overall plan to retain mobile customers and reduce churn 
- Awareness is needed - many people do not understand what Mobile Money is

- Agents

- Need 30-40 days of training

- More than 150 agents in 4 provinces

○ 50 Women agents now

- Sees women agents as key to expansion

- Regulatory Environment

- DAB revising regulation based upon MNO input

- Listening to concerns

- Sees incremental gains

Afghan Wireless Communication Company (AWCC )

(dba Afghan Besim Mobile Money Company - My Money)

Spoke with:

Saeed Haris Hashmie - Senior Project Manager

- Been in Mobile Money business for 1 year

- Without FAIDA support, could not have entered market

- Instrumental in assisting to entre immature market

- Without USAID/FAIDA would not have been interested in entering market

- Customers

○ 20,000 in 26 provinces with $80 \%$ active users

○ 7-9 Corporate customers

○ 4,000-5,000 payroll clients

- Types of activity

- Electrical bill payments soon

- On verge of New Kabul Bank (NKB) deal

$\circ$ NKB interested in reaching customers where there are no branches

○ Pilot project with MOF

○ $70 \%$ activation

○ $30 \%$ via Mobile Money

- Transfer funds to other Provinces and each other

- Afghan Local Police deal where NKB has no branches

○ Ministry of Education deal in process

- UN project

○ World Food Program (WFP)

- Started in 2014 with 400 beneficiaries, now 7000-8000

- Helps donor to collect data re: beneficiaries

- In 7 provinces and targeting 24

o Targeting 68,000 families

- Merchant's transact with NKB

- Maximum security with maximum flexibility

- SIM/PIN/NFC/Biodata/can have additional nominee

- Electricity bill payments 
- FAIDA

- COP great help in marketing

○ Great support - without would have been next to impossible

- Without FAIDA would have had many problems

- High capital costs would have kept them out of market

○ Says $75 \%$ Satisfied

○ $25 \%$ not satisfied due to policies, not performance

- AWCC is concerned about the bottom line/FAIDA not so much

- Did not miss single opportunity to help

○ Lobbied Regulators

- Removed obstacles

- 25\% dissatisfaction - doesn't blame FAIDA

- Dissatisfied that grant distribution not based on performance

- If other MNO's did not perform, funds should be reallocated to those who do

- If funds left over, should fully distributed to those that can utilize them

- Says AWCC focuses - other MNO's do not

- Says other Co's not progressing

- Says grants allocated on existence, not performance

- Now in better position to assist the unbanked

- Could not have moved forward or participatedwithout FAIDA

- Grants

- FAIDA only allowed two concepts for each MNO

- Did not implement - AWCC focused on building infrastructure

- Says other Co's not eager - AWCC focuses

○ Other Co's not progressing - not changing lives

- Recommendation

○ Funding should benefit FAIDA's mandate and users

- Regular meetings with MNO's at fixed time

- More collaboration needed with FAIDA

- Bill payment decision should have been collaborative

- Decisions made without taking in to account needs of users

- Concerned about qualifications of partners

- Concerned about AWCC brand name

- Flow limit is $25 \%$

- Innovation Fair may have predated AWCC participation

- Lack of Awareness is the major issue

- Need support of CBA and the Sector

- Should be reduced risk for CBA and participants

- CBA should promote innovation

- Culturally need support

- FAIDA is "white collar people"-Product needs the understanding of common person

- Need cultural support

- Charges

$\circ$ Costs is 15 Afs one-time charge to register 
- Costs is 15 Afs per transaction

- Shared with Agent if they initiate

- If no Agent involvement 15Afs goes to AWCC

- Have 90-100 merchants in Kabul

- Allowed to take bills to Agents - Agents will pay on customer behalf

- People trust local agents - don't need SIM card

- Agents don't receive USAID???

- Regulatory inhibitions

○ Limits on transfers - salaries only allowed direct deposit to bank accounts

○ Limits revenue collections to banks

- Need regulatory fix to allow salaries to Mobile Money - Reg should say "Bank or Mobile Money"

- Says 20Million on telecom system

Afghanistan Payment System (APS)

Spoke with:

Ismail Khan - Head of Finance and Administration

- Expects to be "switch" for Afghanistan and from Afghanistan to other countries

- Received grant from FAIDA

- Says FAIDA supportive, but took a lot of time to respond

- Grant was extended to Oct 2014

- Mostly computer and office equipment, air conditioners and

- Second grant is in process for operational support (house rents, salaries)

- Says may need business and technical assistance

- World bank is assisting with data center

- Says any Financial Institution registered with CBA may participate

- MNO's may participate

- Expects to be live in Nov 2015

- Looking for business models to emulate

- Egyptian CSC is a good model

- Government will have access to reports to track transactions

- Needs support to become profitable

- Continues to supply reports to FAIDA although grant is expired

- Response time is good

OXUS

Spoke with:

Salim Khan - President and CEO

Maroof Ziaey - Chief Operating Office

Nizauddin Amiry - CFO

Mona Haidari - Marketing Manager

- FAIDA stepped up and provided assistance at the time it was needed 
- Says OXUS has aggressive goals

- Says OXUS contributes $25 \%$

- Target was 250 clients - says disbursed to 254

- Target was $20 \%$ female participation - says actual was $36 \%$

- Uses average household has seven members

- Says 344 jobs created

- Utilized a short-term consultant

- Held internal capacity building seminars

- Building a network in the Provinces

- OXUS existence dependent upon FAIDA

- DCA agreement helped to diversify funding and was a huge help

- FAIDA approached OXUS to offer help in connecting with bank

- FAIDA helped link OXUS and MIFSA

- Says OXUS \#1 in sector and gives partial credit to FAIDA

- FAIDA helped with:
○ B-2-B Roundtables
- Client referrals
- Business Plan Seminars
- Marketing

- Says 17 MFI's have folded

- OXUS is nationwide in 17 Provinces

- OXUS actively recruits female staff

- $50 \%$ of credit managers are female staff

- Two Department Managers are women

- Says main office should be role model for the field

- Says OXUS involves females in decision making

- Says females are more responsible

- If female is empowered, household can be empowered

- Plan going forward

- Concept paper to FAIDA

- Aggressively promoting women

- Two promotions to Credit Manager

- Targeting women for lending

- Focus on Youth who want to start businesses

- Reduced minimum size of loans (group lending)

- Increased average marketing area from 10-20 kilometers

- Policy and Review Committee meet every month

o Watch client day to day activities in markets

- Need to focus outside main cities

- Identify role models and success stories and publicize

- Promoting group lending product

- Promote Sharia-compliant products

- Success story

- Tailor came in for a loan to start business 
- Now doing $\$ 30,000$ per year after 3 years

○ Employs 4-5 people in her shops

- Mobile Money

○ Thinks is positive

- Can help OXUS expand territory, but not now

- Youth

- Says need to build sustainability first, then bring in innovation

- Wants to encourage education by providing loans

- Hired those trained through AIBF

- Need to link education and career guidance

- Wants to help with business plans

- Out of 75 clients, probably 10 will be successful

- Take success stories to Universities

- Take a practical approach with youth

- Will advertise through social media, Facebook, Website, client referrals, etc

- Need to emphasize "customer service" - missing point in Afghanistan

- OXUS provides month long training for new credit officers

- New Branch Managers receive 1 week OJT by shadowing current managers

- Deals with poor performance by utilizing assessments, identifying skills gaps and retraining

- Had a $70 \%$ turnover, now it is $1 \%$

\section{FINCA}

Spoke with:

Sayed Mohd Ali Rawnaq - Chief Operating Officer

- Mentioned LB says he is very helpful

- FAIDA provided spreadsheets for internal reporting

- Simple but effective tool

○ Still utilizing

- FAIDA is referring clients and business contacts

- FAIDA providing some funding

- Has two Islamic financial products

- Mirabi

○ Mu???? - group lending product for females $-75 \%$ of product females

- Sees movement from conventional to Islamic products

- Islamic products in flux

o Will take a while

- No standard definitions of Islamic products - Clerics in different areas disagree

- Bank in 10 Provinces with 20 branches

- Starting agricultural livestock lending

- Businesses are $90 \%$ of loan volume

- Has own internal training department 
- Two recent trainings:

- New products and systems

- Manager training

- Worldwide FINCA has training academy he can draw on for support

- Says needs capacity building

- Needs innovation

- 2015 Assessment for deposit taking

- Has software form Jordanian company

- Savings module

- Needs to work on branding of branches

- Mobile Money

- Customers lack confidence

- MNO's start product, but do not invest in it

- Long-term view is required - here the view is short-term

- Problems with Agents not being adequately trained

$\circ$ There is a strong regulatory environment

- Awareness is a major issue

- Lack of proper context is a major issue

- Need word of mouth advertising to expand

- Difficult to trust new Mobile Money services

- Local Hawala is competition

- Need a behavioral change

- Has six female loan officers and one female Branch Manager

- Female loan officers bring in females wishing to borrow - needed to communicate

- Big issue is liquidating collateral - it takes two years

- Lending range 5000AFs to 1 Million AFs

- Most loans over 15,000AFs

- Reports loans to registry

- Does not register collateral

- Performs $100 \%$ of their own appraisals - need local knowledge to know value

- Sent one proposal to FAIDA last week for paperless banking

○ Has electronic application via tablet

○ Will cut costs - too much paperwork now

- Will try mPaisa later, not now

- Needs consultant for Sharia revamp

Microfinance Investment Support Facility for Afghanistan (MISFA)

Spoke with:

Bahram Barzin - Managing Director

- Was ARIS Deputy COP 5.5 years ago - helped develop FAIDA SOW

- FAIDA provided grants

○ Helped with MISFA strategic plan 2.5 years ago

○ Joyce Layman imbedded advisor 
○ Mentoring and Super???? four years ago

- Supervises MFI's

- On AIBF Board

- Provides $90 \%$ support to AMA

- FAIDA had no role in setting up AMA

- Split off AIBF and AMA

- AMA was set up for coordination among MFI's and advocacy

- There was a three-way split

- Gave up regional offices and regional coordinators

- Radio campaign transferred to AMA

- MISFA owned by Central Bank

- Future needs:

○ World Bank to fund \$20Million

- Needs nothing from FAIDA

- Microfinance institutions in 20 Provinces

- Sees 5\% PAR as acceptable

- Doesn't see deposit as a source of lending capital

\section{3/05/2015 KABUL AFGHANISTAN}

\section{Gender FGD and Survey 9:30}

Evaluation Team:

- Abdul Bari

- Wajiullah

- Zahul

Number of participant: 4 female 2 male

Six people were participated during the this FGD session two of them were aware of FAIDA program and one of them Saleha actual participated in the Women's Access to Business Opportunities and finance, the team had invited 10 participant and six participant came to the FGD. At the beginning the team administered the questionnaire and then the session followed up with FGD.

The discussion had the had the following key points:

We as women have a lot of problems and difficulties which cultural and tradition, family issues it took us while to convince the family to allow us to work in this traditional society where all the power of decision making is with men in main time economical problem are also a challenge for us. We have ministry for women but its polices are not acceptable because they can solve any of our problems.

Women has been tortured in this country they have been treated very badly and those women who has power they its equaled to nothing and they cannot take decisions.

It is very hard for women to work in this country. Men has all the benefits in this country 
The problem is let's say a project came and helped or started a small business to a woman and she learned the business and started production now the question is where to sell this. We do not have market today women weaving carpet

We have not participated in FAIDA's programs and no one has helped us but when we participated in other workshop it give us courage and self believe that as women we can work.

Saleha I participated in Women's Access to Business Opportunities and finance but I went home and discussed this issues of getting a loan the family decided not to go for loan because of the interest which forbidden.

\section{Matchmaking FGD and Survey 2:30}

Evaluation Team:

- Abdul Bari

- Wajiullah

- Zahul

Number of participant: 4 female 3 male

All participants has participated in the matchmaking event but none of them has loan from any bank of institution

We have participated in three matchmaking workshops and after the workshop the FAIDA team contacted us and asked us to prepare a list of how much money we need and the range for each business.

We learned a lot from the event specially marketing and also we learned how apply for a loan and get the money.

We learned how prepare our financial statements even we have not received any grant but we learned how to apply for a grant.

The workshops and seminars which were by FAIDA were effective like some presentation for small and big business; they bought some international businesses and shared their ideas Some of our expectations were not met because we thought we will be introduced to the donors unfortunately it did not happen.

When heard about FAIDA we thought we will financially benefit from them.

They introduced the banks to us and it is ok that they are called Islamic banking but when we went to some back like Ghazanfar Group we talk to them they could convince us on their Islamic products because they were taking of Mudaraba and but they were not ready to accept the lost. If they'd accept the lost the issue of interest raised.

The bank wants to do their own business they do not care about us. In the conference they said that they will charge between 9-10\% when we went and allied they told us that they charge $21 \%$.

All loan that they are given are none Islamic and $t$ also what they have promised in the conference when we went to their banks and offices the interest rate changed and own they were telling us a higher rate up $21 \%$ by Oxus. 
It is good that they introduced the businesses to the back but people has experienced this before from my point of view it will be effective for some but not for all.

They could not convince us on the Sharia products as interest is forbidden in Islam.no one (Banks) followed Islam and they wanted to do their business.

The events were effective since they trained us in book keeping and the benefits of book keeping if someone do a business and he do keep the record at the end of the year he/she will not know the profit and loss.

From my point of view these conferences were very effective because it showed us how manage our work. I as construction company when participated in matchmaking conference in USA before we were using Russian standards but now we are familiar with very strong American construction management. Now it up to the companies how much they learn from these events. Now learned new skills and the capacity built and all of them are the results of the Matchmaking conferences. T main time they had three problems first was the Islamic and conventional issue that we could not get loan. The second problem was they promised in the conference one thing and in realty it was different. The third problem was that most of our companies lucking the ability to secure a loan.

Most of the donor money was utilized by international organization and in the most cases it was our fault because we as Afghan companies never tried to maintain the standards.

FIADA is doing a fine job but unfortunately we cannot work with them directly and we never been introduced to them as business. Faida should find donor for the businesses as part of matchmaking activity.

We recommend that in future matchmaking programs they introduce some income generation project and also bring some international businesses to the conference for exchange on ideas and show us new technologies which will help Afghanistan to avoid import of goods.

They should at least bring two businesses per year to show their work practical not in theory.

\section{6/05/2015 KABUL AFGHANISTAN}

\section{Mobile Money FGD and Survey 9:30}

Six participants

Two has stated working as and four are still waiting

Two who has started:

People were very happy with the program. And they companies also paying very high the agents we had 5700 agents some of them we working in other places but they were our agents and they were bringing us the users.

The number of agents came down because we were receiving from $6-9 \%$ commission and now it is dropped to 4-6\% because of the sales went down after the election.

We were working with Etisalat, Roshan and MTN.

The number of agent came down due to the reason above and also the technical issues of the mobile networks in money delivery when they wanted to send money the system was confirming that it is sent but the person on the other side was not reviving it or sometime they were trying and trying the money was not going through this was one of the issues which caused in reduction agents and users. 
When the number of agent went down the customers also decreased with that the company which we are working with it brought its number of staff down also from 102 to 4 people.

The other problem were that the system was in English and most of the costumers or users were either uneducated or knew no English

To encourage the users we were given them the simcards for free and sometimes the agents were paying 100 afs from their pocket just to have them using the system. People were no trusting the system since some scams were going on then what we did was used uniforms for our agents it was very difficult to convince people sing the system.

It took us almost four months to start.

Every company is thinking of making money if this mobile money was starting it would be good for the country and also and ease to the people and there was no need to go to banks for them.

\section{Reponses of the four who has not started}

We have participated in a conference in Qasre Noween hotel 200 member of Durukhshan was there and after that we went to workshop in continental hotel where again participant form six central provinces came and there the use of mobile money was introduced and also we give them our area of coverage. Sometimes later AWCC send its members in our area and they checked all of our business and we have been promised that they will contact us back it not happened for one year. They said we will come back in week. They did share their address and we do not know where to go to ask for the status of the project.

One of the participant said that near to his store there is a military base in Husin Kot area of Shakar Dara district of Kabul he went to that base and told most of the soldiers who are from different provinces of Afghanistan and told them that from now on I bring and introduce a new system for you all and you do not need to go the bank and money dealer anymore it's called mobile money from here you can send money to your families. They were very happy and the response was very positive unfortunately AWCC ever came back and those people in the base are calling me a lair.

The main problem for us is that we spread the news to our customers that a new payment system is coming and they do have to go to the banks now they are asking all the time what happened to system when you are going to start it and we do not have an answer for them.

\section{6/05/2015 KABUL AFGHANISTAN \\ MSME FGD and Survey 2:30}

Two participants one has loan from:

Azizi Bank 100,000 for 25\%

MISFA 100,000 for $18 \%$ came

One participant came with all his document and also when he find out that this just an evaluation he was very angry and do not wanted to answer any question from team and he wanted to leave the team respectfully asked some question when they know that he is not responding let him and the other person go (in revenge we did pay any transportation).

One participant has no idea who FAIDA is? When he was asked how he came for the FGD he said that he has received a call for the meeting and he was told that the rest will explain to him is the meeting. He could not recall any assistance in any form from FAIDA in the last five years since he is running the business. He owned a spare part dealing company and 
looking for a loan the evaluation team assists him to contact ADF since he is working on spar part of thrashers and tractors.

The second participant he was just introduced to the bank apart from that he have not received any technical assistance from FAIDA according to him without the introduction it was difficult to get loan since he did no knew how to apply for loan and where to go.

The meeting was short and since it was two participant and they had no other issues to discuss.

\section{8/05/2015 BALKH}

\section{Mobile Money FGD and Survey 9:30}

Three participant came from out of ten invited all of them participated in a conference three years ago in Mazar but after that they never heard back of the program. According to them the mobile money program started in that hotel and ended up there.

Someone by the name Engeela Farzan called them and told two of them that come for the meetings we have some project for you. When they came for FGD they find out that they are talking with evaluation team not someone with bug of money.

They asked one participants from Zari District which is $130 \mathrm{KM}$ away from Mazar.

According to the participant the mobile money program is a very good initiative and they are regret to see that it is not started in the last three years since it was announced by this time at least $30-40 \%$ of people would have been aware or sing this program.

According to Rabia Maryan who works with female formers for her it would be bit challenging because most of her farmers in the five provinces that she works do not know how to read or write but sill she can use it for its costumers where she can sell good through mobile money.

Education would be challenge for the mobile money because most of the people even educated are struggling one of the participant who is graduated from Agriculture faculty and he is using mobile phone for the last 12 years says that he is still having trouble to top-up his phone and always need to asked somebody to help him and he says now for a common man it would be very difficult to use it massive education is needed for people and also the network companies has to gain the trust of the people because there some instances where people lost their phone credit or at least there has been complain now how people can trust to add money is their mobile phone

\section{8/05/2015 Balkh}

\section{MSME FGD and Survey 2:00- 4:30}

Six participants 4 female and 2 male

One participant had evidenced more assistance then the matchmaking conference the company called Nizam Aiwa plastic company they have received technical assistance to put to gather a proposal for ABADE program. The rest had no other experience with FAIDA.

One lady said that someone by the name of Kobra came and took my photo and copy of my Tazkira and after a week asked us to go the bank.

FAIDA's assistance helped us to get the loan and with them we would been able to get the loan but through them it was very easy it helped in collateral issue the banks were a bit soft 
on us since we had a grantor in form of FAIDA playing a role between us and the banks it changed the behavior of the banks in positive way.

It also helped us I way that they told come to a certain bank if we would be stranded for choice it helped us.

The cooperative that we have received loan (IIFC?) they were not giving more than 15000 afs but though FAIDA they paid us 30000 Afs.

The people that we have hired would not been possible if we had no money in hand we got the loan that we were looking for expanded the business somehow and hired more people and without FAIDA's assistance it was not easy for us to apply for loan.

Collateral registry and interest rate is our biggest issue some financial institution does not accept our shop or other papers if they can provide s loan with prepares in hand would be a big bonus for us.

We are interested doing deal trough mobile money

Once participant participated in mobile money conference two years ago.

Mobile money is good if the company pay us for the transaction that we make through our customers.

If we were managing FADIA we would find banks for women who had no interest rate even we know it is not possible. We would work on marketing issues for business and also conducting business events for them. We would have done and need assessment since its name is profit we would assess which company needs what sort of assistance instead going to the banks and those who already has money.

\section{8/05/2015 Balkh}

MSME FGD and Survey9:00 are

Two participant came individually the questionnaire was applied the first both participant had no idea what they were doing and the team member explained the objective of the program.

Participant number one we received a call from FAIDA and they told us since you are good client of AIB and we have some project for companies like come to the hotel to talk on this issues.

It looks like all participants who were invited by FAIDA false promises has been made with

them in order to encourage them to participate in the survey.

Participant number one has received loan from azizi bank for 15\% interest

The second participant has received loan from azizi bank for a higher rate of $25 \%$ according to him all of the profit that he made had to pay it back in form of interest.

$\mathrm{He}$ is running a juice and water company and the team introduced ADF to him and he was unaware of ADF and he was very happy to find out about ADF and also he indicated that that the same assistance was provided by FAIDA there was no difference in FAIDA's and the evaluation teams advocacy. He has no plan to export his products outside Afghanistan since the company maintain low standard and their production in not according to international norms. If they have the machinery that they have the quality so they can make it standard.

\section{3/05/2015 Balkh}

\section{Gender FGD and Survey 2:00-4:00 PM}


Number of participants for the focus groups 8 one male and 7 female six of them and interviewed and all of them participated in the FGD.

One participant looks back at FAIDA's assistance and she thinks that

It did not help them because they applied for loan five times and one time was able to get loan she said she had little knowledge and there was no one to help them secure the loan.

We want to export our produced to outside the country we are doing it right know but it is limited and it based on request if FAIDA can help us on this regard it will helpful and also to expand our business to their provinces.

Women has many problems and facing a lot of difficulties in Afghanistan and going through different phases of issues all the time first they have to convince the family and then has to find its place in the community and going all the way in society and make her business accepted by people.

Most of the women are economically weak and they need support.

If women wants to start a business or want to go out of her home to work due the tradition it is difficult and people in the community will start talking about it every step is problem once we start a business as women that find costumers.

\section{May 20, 2015 Balkh}

\section{Matchmaking FGD and Survey 9:00}

Number of participant 11: Male (5) Female (6)

First of all we have seen a lot of programs and project who came to Mazar worked they were or their results were short term. The difference in FAIDA is that they are doing the activities back to back if they have workshop on a specific subject they do a follow-up workshop a step further even if they workshop after a year they invite they people from last workshop.

FAID has provided a lot of facilities for all business specially their work with women worth mentioning. FAIDA's intervention influenced not only the six people who are here for FGD but also for all those women who attended the conferences, workshop and trainings all of them benefited from FAIDA. USAID should support such a project specially those who work with women.

The matchmaking workshop was very effective first of all it created relations for those who has small or big businesses. Most of people might have been aware what are terms and condition for back for lending money how apply for loan and solve the money problem of their businesses so nice again I can say it created a network between backs and businesses. Most of people applied for loans and some even secured the loans we are in contact with them. I have received loan from Agha Khan Bank to expand my business and I am very happy for that.

One of the percipients has participated twice in the B2B workshops but he has not started a businiess yet still he was happy with result and he is going to start a business soon.

The matchmaking conference was good bank were there and we were their it was effective but is was not core activity and most the assistance which are coming from USAID it goes to specific number people and those people have facilities in hand they know the people and also has references. We tried very hard to receive some assistance as marketing company but they were rejected in deferent ways. Some people would know about these banks and some who even learned about the banks they cannot use this knowledge our company is the 
example we cannot use any of the products from the banks because the interest rates are very high and we cannot go for it.

The matchmaking conferences were very effective because every small business especially women start with a small money and it provided them that platform of business growth. Now they applied for loans and from a very small amount they started and it very good working capital for them if they worked hard and they have been able to expand the business and increase their activities. If a men or women did work hard and know they spent money that received from back in form loan and know they in loss to make it sample the matchmaking was their know it depend on the planning and management of each individual to get benefit from it or not if someone has very good plan even they can save some small money from the small business if they're not proper planning and management even if they have all the money from the back it mean nothing.

We know some women who received loan from these back they started poultry. Livestock, some made carpet weaving factories, or they bought some sewing machines even they have some small contract they even expand their businesses but any way matchmaking was effective.

FAIDA helped women a lot in securing the loans FAIDA goes and checking the work and condition of the business after review everything they make a concept note and sending them to the Micro Finance institution and telling them that this women with this condition have receive an X amount of money now the MFI just check the collateral documents and then they call person to come and get the money. Then they send an email to FAIDA that we have given an $\mathrm{X}$ amount loan to this person. It means all work has been done by FAIDA office.

The business to Business fair that was held in Mizar was very interesting no I made a contract with Indian company now most of the other companies wanted to work to gather from my point of view FAIDA should perused them and if they needed any support they have been supporting them, what we heard or seen most FAIDA's focus is on the loan issues they can expand that more and focus on business pan and management issues.

The Indian who came for B2B even they were interested in our products FAIDA could follow the situation until we were connecting and making an agreement or we getting an order from them. And also FAIDA could take us to some exhibitions in India or let say at international level.

My suggestion is that FAIDA should work with production companies and link them to international marketing I am repeating that they take some outside country for exhibitions.

exhibition are very good both for introduction of products and also finding good costumers let say if we take company to India when they see their production they can produce according to their needed and choice of theirs.

End of the story we say that the work that FAIDA is doing is acceptable to some extent the only point that they are missing is the follow-ups if they this or would done this for the last three year by know we would had some strong businiess in the region due their contribution and interventions.

SMSE Focus Group: May 24, 20151300 hrs. 
I applied for loan to a bank since I have been a lady or any other reason they did not approve my loan but when I contected FAIDA and they introduced me to the Aryan Bank they give the loan I think the main prolem was that I am woman and they give loan to man easily.

If some one applies for loan or some introcuded by FAIDA there is big difference and the chances are high to get the while you introduced.

They have registered us and told us when we had any project for we will get back to you.

Tanin and FARAH Goster were also linked with ADF trough FAIDA.

None of the participant were hapy about the loan products and they were saying interest is forbidden in Islam.

They had complian that why FAIDA has just one employee in the region.

May 24, 2015

1600 hrs.

Meeting with Mohajar the RC of FAIDA for west.

He works with FIDA since April 2014

His main duty is to provide coordination for enterprise sector of FAIDA.

1. Company

2. Identification

3. Evaluation

4. Amount Needed

5. Concept Note

6. PBRC Review

7. Sending the Document to Bank

8. Follow-up
A. Accept
B. Reject
C. Decline by Client
D. Pending by Client

Most of loans are rejected due to collateral or its documents.

Some times the client decline that they are not interested in the loan prodcuted which is offered by the bank or they change their mind not to go for a loan.

In some cases the client ask the bank to keep his process on hold if there is any major market issues.

$\mathrm{RC}$ or FAIDA helps the client technically but they are not the becoming grantor for them.

Once the loan is approved the $\mathrm{RC}$ is doing three visits to the company at beginning, middle and end of the loan. If RC see any problem in the company FAIDA try to make a buniess plan for them.

The RC do write a follow-up report.( Laying)

They received client through:

$\checkmark$ Different Associations 
$\checkmark$ B2B events

$\checkmark$ AISA

$\checkmark$ Trough RC

$\checkmark$ Client come to FAIDA

FAIDA has done one of the three innovation fair in Herat

The Fair was held for six sector Health, Eduction, Clean Energy, Water Sanatation, Agriculture and ICT.

60 boath were for local and 30 for internation companies.

Morethen 3000 compnies visted the fiar.

All matchmaking were recorded during the event

After the even FAIDA prented a business directory and share it with every one.

\section{WOMEN Access to Finance FGD.}

\section{May 25, 20151300 hrs.}

Afghanistan is traditional country and it is very difficult fr women to start any work outside her household and even in side. We as women struggled a lot and also the misogyny is a big issue in our area.

Some project come to area and says to do the work with man and also sometimes they give a percentage like 70-30 for men and women.

The percentage in the bank are very high and also most of the parcipants were complaining that to start with it is very difficult repay the loan in one month.

Their was no other program for women in Herat except they have been invited to matchmaking seminar.

\section{Matchmaking FGD.}

\section{May 26, 20150900 hrs.}

Our expection was met suring the even but we mentioned their that we want loan for longer period with less interest. But the loan was for short time and the interest rate was very high.

At the loan repayment should start after three month not one month.

No one in the 16 participant has applied for loan.

We have an association which has 120 companies but no one has applied for loan because the interest.

We want more Islamic loan products.

FAIDA was very good in awareness but .

\section{Herat:}

The participants appreciated the exhibition and were able to a good marketing in in the exhibition established by this office. Their relation has improved with the national and international beneficiaries.

But the workshops for giving loans were not useful and were not able to utilize the amount of money for their productions. The reason was that their revenue was not on a monthly base and had to wait for their annual income and stated that the current economy condition of Afghanistan is not suitable for good business outcome. They added that, all their works are not developing that much and couldn't be able to provide the payment of the loan on the 
monthly period.

FAIDA office provided Islamic and standard banking loans to them whereas they were satisfied from the Islamic banking system but didn't show any sort of interest accordingly. Overall the participants were full satisfied from the process and marked it as a useful act.

Establishing of the workshop about making business plan was the great one and stating that the participants of this workshop took professional actions for their works and was important for their professionalization.

Establishing of the exhibitions in the neighboring countries for familiarization of the foreign beneficiaries were requested and wanted to know the new and modern systems of the business and trade.

Reason of not utilizing this loan is problems and stress in their jobs and added that instead focusing on their own works and using the opportunities, they would be thinking on how to pay their monthly loan and their shouldn't be delay on the payment due to its interest rate and its late payment fine, even if the payment is late, the bank might have access to their goods and sale them in markets to gain their loans. That's why they stated that it might be a stress to think on its payment period.

Payment of the money after one month was impossible, particularly for those who wanted to get money for purchasing new machineries and replace it with the old ones they have. As a big period of time would have to be utilized for purchasing, establishing and processing the goods and items to the market and would not have enough money on their own paying the bank by end of the month.

They wanted to have the repayment period longer whereas they could use the money easily. Once more, the presence of female were limited in the exhibition and this act was very disappointing for the females. It seems that using of big budgets in establishing such exhibitions, would be good to increase the number of booth's. one of the ladies who is having recording studio resubmitted his booth after some time and added that, this exhibition is for selling more items and she doesn't have that much items and goods to sell and having this booth is only wastage of time for her and no income and revenue is gained.

The tasks that this office have fulfilled were not comparable to the ones held in India and Pakistan and saw the new and modern ones. Their request was to have such exhibitions in the future. 


\section{Disclosure of ANY CONFLiCTS OF INTEREST}

[The Evaluation Policy requires that evaluation reports include a signed statement by each evaluation team member regarding any conflicts of interest. A suggested format is provided below.]

\begin{tabular}{|c|c|}
\hline Name & \\
\hline Title & \\
\hline Organization & \\
\hline Evaluation Position? & $\square$ Team Leader $\square$ Team member \\
\hline $\begin{array}{l}\text { Evaluation Award Number } \\
\text { (contract or other instrument) }\end{array}$ & \\
\hline 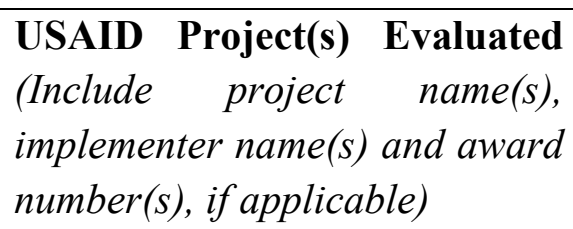 & \\
\hline $\begin{array}{l}\text { I have real or potential } \\
\text { conflicts of interest to disclose. }\end{array}$ & $\square$ Yes $\square$ No \\
\hline $\begin{array}{l}\text { If yes answered above, I } \\
\text { disclose the following facts: } \\
\text { Real or potential conflicts of } \\
\text { interest may include, but are not } \\
\text { limited to: }\end{array}$ & \\
\hline $\begin{array}{l}\text { 1. Close family member } \\
\text { who is an employee of the } \\
\text { USAID operating unit } \\
\text { managing the project(s) being } \\
\text { evaluated or the implementing } \\
\text { organization(s) whose } \\
\text { project(s) are being evaluated. }\end{array}$ & \\
\hline $\begin{array}{l}\text { Financial interest that is } \\
\text { direct, or is significant though } \\
\text { indirect, in the implementing } \\
\text { organization(s) whose projects } \\
\text { are being evaluated or in the } \\
\text { outcome of the evaluation. }\end{array}$ & \\
\hline $\begin{array}{l}\text { 3. Current or previous } \\
\text { direct or significant though } \\
\text { indirect experience with the } \\
\text { project(s) being evaluated, } \\
\text { including involvement in the }\end{array}$ & \\
\hline
\end{tabular}




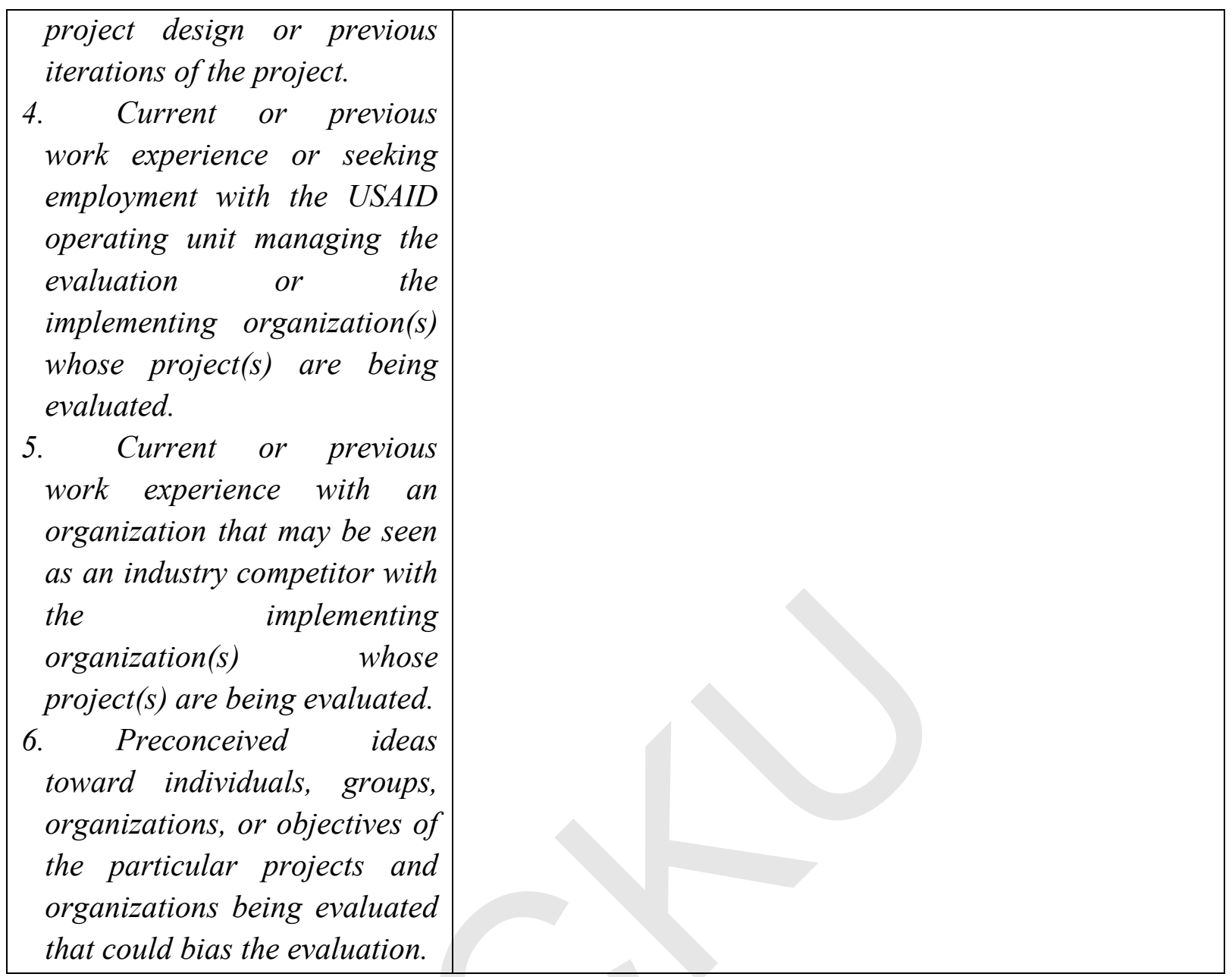

I certify (1) that I have completed this disclosure form fully and to the best of my ability and (2) that I will update this disclosure form promptly if relevant circumstances change. If I gain access to proprietary information of other companies, then I agree to protect their information from unauthorized use or disclosure for as long as it remains proprietary and refrain from using the information for any purpose other than that for which it was furnished.

\begin{tabular}{|l|l|}
\hline Signature & \\
\hline Date & \\
\hline
\end{tabular}




\section{Statement Of DifFerences}

Differing opinions among team members relative to conclusions or recommendations should be reflected here. 
Checchi and Company Consulting, Inc.

Afghanistan SUPPORT-II Project

Wazir Akbar Khan

Kabul, Afghanistan 